UNIVERSIDADE DE SÃO PAULO

INSTITUTO DE PSICOLOGIA

PROGRAMA DE PÓS-GRADUAÇÃO EM PSICOLOGIA CLÍNICA

MESTRADO EM PSICOLOGIA CLÍNICA

Dissertação de Mestrado

\title{
O SUPEREGO E O IDEAL DO EGO: UM DESTINO AO ROMANCE FAMILIAR
}

\section{LIZANA DALLAZEN}

Orientador: Prof. Dr. Daniel Kupermann

São Paulo, julho de 2010 
UNIVERSIDADE DE SÃO PAULO

INSTITUTO DE PSICOLOGIA

PROGRAMA DE PÓS-GRADUAÇÃO EM PSICOLOGIA CLÍNICA

MESTRADO EM PSICOLOGIA CLÍNICA

O SUPEREGO E O IDEAL DO EGO: UM DESTINO AO ROMANCE FAMILIAR

Dissertação de Mestrado

LIZANA DALLAZEN

Prof. Dr. Daniel kupermann

Orientador

São Paulo, julho de 2010. 
LIZANA DALLAZEN

O SUPEREGO E O IDEAL DO EGO: UM DESTINO AO ROMANCE FAMILIAR

Dissertação apresentada ao programa de Pós-Graduação em Psicologia Clínica do Instituto de Psicologia da Universidade de São Paulo, como requisito parcial para a obtenção do Grau de Mestre em Psicologia Clínica.

Prof. Dr. Daniel Kupermann

Orientador

São Paulo, julho de 2010. 


\title{
AUTORIZO A REPRODUÇÃO E DIVULGAÇÃO TOTAL OU PARCIAL DESTE TRABALHO, POR QUALQUER MEIO CONVENCIONAL OU ELETRÔNICO, PARA FINS DE ESTUDO E PESQUISA, DESDE QUE CITADA A FONTE.
}

\author{
Catalogação na publicação \\ Biblioteca Dante Moreira Leite \\ Instituto de Psicologia da Universidade de São Paulo
}

Dallazen, Lizana.

O superego e o ideal do ego: um destino ao romance familiar / Lizana Dallazen; orientador Daniel Kupermann. -- São Paulo, 2010.

$154 \mathrm{f}$.

Dissertação (Mestrado - Programa de Pós-Graduação em Psicologia. Área de Concentração: Psicologia Clínica) - Instituto de Psicologia da Universidade de São Paulo.

1. Superego 2. Ego ideal 3. Identificação (psicanálise) 4. Análise dos sonhos I. Título.

RC504.5.E3 
UNIVERSIDADE DE SÃO PAULO

INSTITUTO DE PSICOLOGIA

PROGRAMA DE PÓS-GRADUAÇÃO EM PSICOLOGIA CLÍNICA

MESTRADO EM PSICOLOGIA CLÍNICA

LIZANA DALLAZEN

O SUPEREGO E O IDEAL DO EGO: UM DESTINO AO ROMANCE FAMILIAR.

COMISSÃO EXAMINADORA

Prof. Dr. Daniel kupermann

Presidente

Prof. Dr. Luis Cláudio Figueiredo

Universidade de São Paulo (USP)

\author{
Prof". Dr ${ }^{\mathrm{a}}$. Mônica Medeiros Kother Macedo \\ Pontifícia Universidade Católica do Rio Grande do Sul (PUCRS)
}

São Paulo, julho de 2010 


\section{AGRADECIMENTOS}

Ao prof. Dr. Daniel Kupermann, meu orientador, por quem sou imensamente grata por me receber prontamente em seu grupo de pesquisa, depositando confiança no meu projeto de mestrado, orientando sempre com humor e respeito ao meu trajeto clínico e teórico e tornando-se uma presença sensível diante dos impasses desse percurso, meu afeto e admiração.

Aos profs. Dr. Luis Cláudio Figueiredo e Dra. Mônica Kother Macedo, pelas valiosas contribuições no exame de qualificação e ao longo do desenvolvimento dessa pesquisa, pela disponibilidade de participar da banca de defesa do mestrado, contribuindo para o meu crescimento acadêmico e profissional, meu especial agradecimento.

Aos profs. Dra Sophie de Mijolla-Mellor e Dr Luiz Prado de Oliveira, pelas orientações pontuais, que indicaram caminhos pertinentes a serem seguidos nessa pesquisa, obrigada.

À psicanalista Eurema Gallo de Moraes, pelo constante incentivo para enfrentar os caminhos desconhecidos, pelas leituras atentas, pela incansável parceria nos momentos de estudos e discussões teóricos, meu carinho e gratidão.

À Valéria Quadros, pela fiel amizade que construímos a partir da afinidade que temos com a psicanálise, pelas intermináveis discussões a respeito dos criminosos e do superego que deu origem a essa pesquisa e pelo auxílio na organização das citações e referências bibliográficas, meu apreço e agradecimento especial.

Às amigas Aline Garjaka, Marcela Schild Vieira, Fernanda Romano e Simone Lisot, pessoas com quem tive o privilégio de conviver, pela generosidade com que me acompanharam nessa exaustiva vida de ponte área e pela alegria que agregaram a esse período de estudos e de vida em SP, minha amizade e meus sinceros agradecimentos. 
A Hernildo, Jussara e Fabiano Dallazen, pelo total apoio nesse ousado projeto de trabalhar em Porto Alegre e estudar em São Paulo, pela vibração com as minhas conquistas e pela acolhida sempre que precisei de um aconchego familiar, sou profundamente agradecida.

Aos profissionais Paula Quental, Sander Machado e Mariana Petry, que, de suas áreas específicas, fizeram acréscimos a esse trabalho, obrigada.

A todos os colegas, amigos, pacientes, que contribuíram para a concretização desse percurso com indicações bibliográficas, leituras esporádicas, discussões de partes do trabalho e pela tolerância com minhas ausências, muito obrigada. 
Ora, ora, meu caro! O senhor! Aqui! Em um local mal-afamado - um homem que sorve essências, que se alimenta de ambrosia! De causar assombro, em verdade. - Meu caro, sabe do medo que me causam cavalos e veículos. Há pouco estava eu atravessando o bulevar com grande pressa, e eis que, ao saltar sobre a lama, em meio a este caos em movimento, onde a morte chega a galope de todos os lados ao mesmo tempo, minha auréola, em um movimento brusco, desliza de minha cabeça e cai no lodo do asfalto. Não tive coragem de apanhá-la. Julguei menos desagradável perder minhas insígnias do que me deixar quebrar os ossos. E agora, então, disse a mim mesmo, o infortúnio sempre serve para alguma coisa. Posso agora passear incógnito, cometer baixezas e entregar-me as infâmias como um simples mortal. Eis-me, pois, aqui, idêntico ao senhor, como vê! - $O$ senhor deveria ao menos mandar registrar a perda desta aureola e pedir ao comissário que a recupere. - Por Deus! Não! Sinto-me bem aqui. Apenas o senhor me reconheceu. De resto, entedia-me a dignidade. Além disso, apraz-me o pensamento que um mau poeta qualquer a apanhará e se enfeitará com ela, sem nenhum pudor. Fazer alguém ditoso - que felicidade! Sobretudo alguém que me fará rir! Imagine $X$ ou Y! Não, isto será burlesco! (Charles Baudelaire, 1975, p.352). 


\section{RESUMO}

A partir de observações oriundas do exercício da clínica psicanalítica busca-se, neste estudo, investigar o conceito de superego e a relação deste com o conceito de ideal do ego. Recuperar o conceito de superego significa revitalizá-lo como instância organizadora do psiquismo, a qual, como tal, abre uma importante via para a potencialidade criativa do sujeito. O ideal do ego torna-se um elemento essencial nesta proposta de investigação, na medida em que precisa ser diferenciado da instância superegóica, para alçar um estatuto metapsicológico próprio e auxiliar na compreensão do alcance da ação desta instância superegóica. Entende-se, pois, ser na articulação desses dois conceitos que reside a possibilidade de fazer um debate metapsicológico que redimensione a noção de superego, de forma a encontrar respostas para as inquietações geradas na clínica psicanalítica. A relevância dessa investigação é a de possibilitar um avanço na compreensão do enlace destes conceitos na teoria e assim evidenciá-los como recursos à clínica psicanalítica. A metodologia utilizada será uma minuciosa revisão de ambos os conceitos, realizada na obra de Sigmund Freud e de autores pós-freudianos, por meio de um modelo de desconstrução do texto. O argumento será desenvolvido pela análise de fragmentos do caso de um rapaz - vítima de uma neurose obsessiva que teve seu tratamento encerrado há alguns anos. Parte-se, então, do pressuposto de que, se houver um reequilíbrio das forças que estão em jogo nos conflitos do superego e do ideal do ego, será possível, via amor de transferência, construir caminhos para a potencialidade criativa, a qual conferirá autonomia para o sujeito no sentido de reconstrução de si mesmo.

Palavras-chave: Superego; Ideal do Ego; Identificações; Contos Traumáticos; Análise dos Sonhos. 


\begin{abstract}
Using observations taken from the psychoanalytic clinic experience, this study aims to investigate the relation between the superego and the ideal ego concepts. Recovering the superego concept means to recharge it with an organizing role in the psychic, which as such opens a significant way to one's creative potentiality. The ideal ego becomes an essential element in this investigation approach, for it must be distinguished from the superego in order to establish its own metapsychological institution and assist to understand the extent of the superego action. Therefore, we believe it's in the intersection of both concepts where it lays the possibility to develop a metapsychological discussion to recreate a superego definition which could settle down some restless issues in the psychoanalytic clinic. The significance of this study is to create a possibility to move forward to understand where these two concepts meet and indicate them as useful resources to the psychoanalytic clinic. The methodology will be a detailed review of both concepts done in Sigmund Freud's and some pos Freud authors' studies, using a text deconstruction model. The argument will be build by analyzing some parts from the case of a young man who suffered from an obsessive neurosis and had his treatment finished some years ago. Therefore, we believe that if there is a balance in the conflict between superego and ego ideal, it is possible, through transference love, to build paths to the creative potentiality enabling the individual to recreate himself.
\end{abstract}

Key words: Superego; Ideal Ego; Identifications; Traumatic Stories; Dreams Analysis. 


\section{SUMÁRIO}

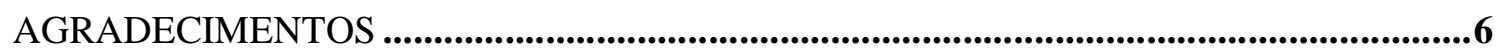

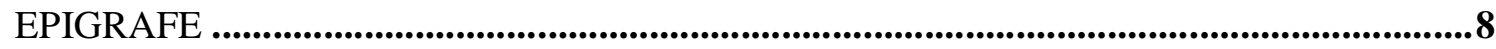

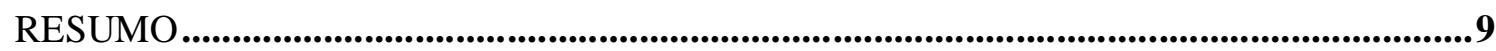

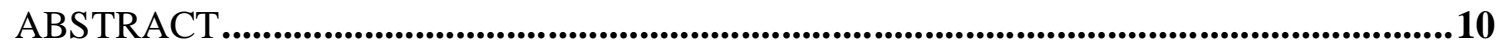

INTRODUÇÃO .........................................................................................................................12

1. RETRATOS DE UM ROMANCE FAMILIAR .......................................................21

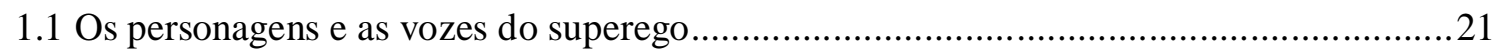

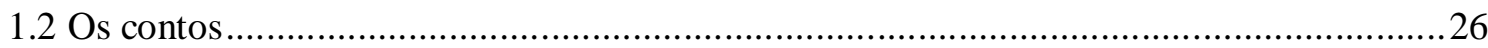

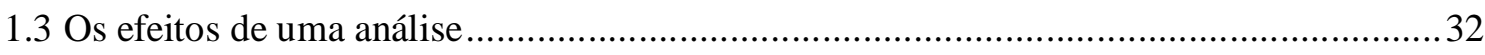

2. SUPEREGO E IDEAL DO EGO: ARGUMENTOS PARA UM DEBATE

METAPSICOLOGICO A PARTIR DE UM CASO CLÍNICO. ......................................38

2.1 O superego é um destino inexorável?........................................................................... 38

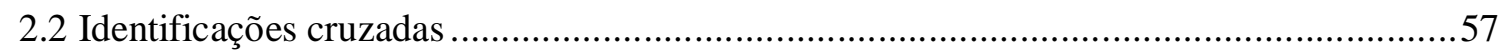

2.3 Ser um grande homem ou um criminoso? ……………..............................................78

3. ESCRITA, O IDEAL DO EGO E OS DESTINOS A PARTIR DE UMA ANÁLISE. 97

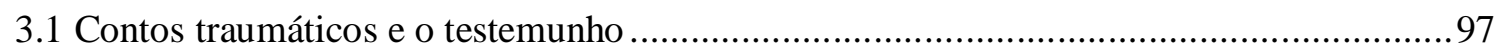

3.2 Ideal do ego, superego benevolente e a sublimação ...................................................110

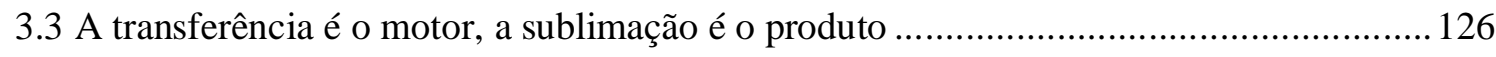

CONSIDERAÇÕES FINAIS.................................................................................................135

ANEXO 1: PEDIDO AO COMITÊ DE ÉTICA.................................................................141

ANEXO 2: PARECER DO COMITÊ DE ÉTICA...........................................................144

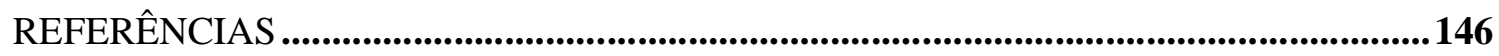




\section{INTRODUÇÃO}

Durante um período de tempo de atividade clínica, certos pacientes que chegaram com um intenso sofrimento neurótico puderam, de forma pouco comum, ao longo do processo, resgatar a capacidade de se expressar pela produção literária. Tais pacientes estavam sob domínio de um rígido superego, inibidos em sua capacidade de amar e trabalhar, bem como de escrever. No decorrer de suas análises, foram trazendo textos produzidos anos antes de procurar a psicanalista e, aos poucos, conforme o desenvolvimento do tratamento, resgataram um desejo de voltar a escrever. Os três pacientes que tiveram esse movimento conseguiram fazer uma retomada exitosa de suas produções no cenário científico e literário em âmbito não só regional, como nacional. Ao mesmo tempo, desimpediram o curso da própria vida amorosa e sexual. O trajeto percorrido pelos analisandos e o recurso usado para construir a independência em relação a seus padecimentos surpreenderam a analista. Com isso, atiçaram a sua curiosidade investigativa de percorrer os caminhos da teoria psicanalítica em busca de argumentos à inquietação clínica.

O que intriga nestes casos clínicos é o fato de a severidade do superego, evidente desde o início dos tratamentos, sucumbir e dar espaço a uma instância psíquica cuidadora e favorável ao campo da criação. Diante desses resultados, as inquietações da analista dizem respeito a essa questão aparentemente contraditória: o superego ser uma espécie de carrasco, uma instância crítica tão severa que cerceia os pacientes na satisfação dos seus desejos e, ao mesmo tempo, poder transformar-se e ganhar caráter benevolente, deixando de ser uma instância psíquica cruel com o sujeito neurótico que busca a análise para se tornar organizador do psiquismo. A transformação da severidade em benevolência seria, então, efeito da análise como um ato de transgressão necessário, que subverteria a ordem tanática a que os pacientes encontram-se subjugados pelo superego em dado momento de seu padecimento! Chega-se, 
dessa forma, ao seguinte pressuposto que conduz a presente investigação: durante a análise ocorre um reequilíbrio das forças do superego mediante a reorganização dos ideais, que abre ao sujeito o seu potencial criativo.

Tomando o espírito investigativo de Freud, pensamos em desenvolver essa pesquisa a partir das reflexões que a prática clínica impôs à analista no curso do tratamento de um jovem rapaz. Foi partindo de questões trazidas pela clínica, que Freud fez suas investigações e avançou na construção do corpo teórico da psicanálise, produzindo uma nova teoria pelo acúmulo de conhecimentos, um método de investigação dos problemas e uma técnica de tratamento. Esse arcabouço de teorias que resultaram do incansável trabalho freudiano nos permite hoje afirmar que é possível fazer pesquisa psicanalítica. E o método utilizado nessa pesquisa foi o método de investigação a partir dos pressupostos psicanalíticos.

Análise terminável e interminável (Freud, 1937/1990) é um trabalho que discute quando e como um analisando, que passa por um processo de psicanálise, está apto a pôr um fim aos encontros com o analista e seguir sua autoanálise - levantando, portanto, a questão de a análise ser ou não finita. Fédida (1988) parte destas reflexões freudianas para ir mais longe ainda. Levanta a hipótese do fim da psicanálise, no sentido do seu desaparecimento cultural, devido aos equívocos cometidos pelos próprios psicanalistas, responsáveis pela aceleração dessa vicissitude. Esta, sem dúvida, é uma questão polêmica no curso de cada análise e entre os próprios psicanalistas.

Dois motivos nos levaram a falar, neste início, sobre análises termináveis e intermináveis. O primeiro é que o tema desta dissertação surgiu a partir de observações oriundas do exercício da clínica psicanalítica, e as questões que apresentamos neste trabalho foram ganhando consistência ao longo dos anos, fazendo parte de um processo contínuo, portanto interminável, de análise. O segundo, porque um caso clínico introduz temas infinitos. O caso sobre o qual nos debruçaremos teve seu início em 2000, quando um rapaz, a quem 
chamaremos de Eugênio, procura a analista para se tratar. O desenvolvimento da análise de Eugênio desembocou na reorganização de algumas questões, fez com que novas indagações surgissem, remetendo ao movimento infinito de terminar e recomeçar uma investigação psicanalítica. Pretendemos utilizar a psicanálise como método de investigação para pesquisar algumas das questões suscitadas durante esse processo analítico, que não cessaram ao final do tratamento de Eugênio. Acreditamos na psicanálise como método de tratamento e de investigação, principalmente quando se parte de um caso clínico que coloca indagações intermináveis, e que, quando investigadas, revigoram o corpo teórico da própria psicanálise.

A investigação está presente desde a história da origem da psicanálise. Se, como psicanalistas e pesquisadores, seguirmos os passos de Freud, não teremos problemas com comitês de ética, pois o pai da psicanálise manteve constantemente uma conduta ética nas suas pesquisas. Optar por seguir o caminho ético indicado por Freud foi decisivo para seguir em frente com a pesquisa em questão e conseguir a aprovação no comitê de ética desta universidade. Só assim, foi possível viabilizar o trabalho a partir de um caso clínico, sem ser preciso solicitar ao paciente um termo de consentimento livre e esclarecido. Fédida (1988) tem razão ao preocupar-se com o fim da psicanálise do ponto de vista dos analistas. É comum nos questionarmos sobre quem hoje em dia tem disponibilidade afetiva e financeira para mergulhar em um tratamento psicanalítico quando existem tantos métodos mais práticos, rápidos e baratos disponíveis no mercado. Menos frequentes são os questionamentos sobre quem são as pessoas que se dispõem a se formar como analistas e quais são os objetivos desses sujeitos - o que recai imediatamente sobre a ética dos que hoje conduzem a psicanálise.

Pensamos que a originalidade de um trabalho psicanalítico e, consequentemente o seu valor, está exatamente na investigação e nos estudos a partir do que a clínica nos apresenta. Esses são os verdadeiros problemas com os quais precisamos nos ocupar. E também, a nosso ver, o caminho da pertinência clínica e da veracidade da psicanálise, o que dará fôlego à sua 
existência por muitos anos ainda. A teoria surgindo da clínica e não o inverso - situação em que os pacientes são engessados dentro de próteses teóricas. Nesse sentido, nos identificamos com a ideia de que a psicanálise, com Freud, é produto da teorização de uma prática, os impasses da clínica reformulando a teoria, e a teoria dando um sentido - direcionando - a prática (Kupermann, 2008).

Possivelmente, o procedimento ético e as questões que esse caso clínico acrescenta à presente investigação psicanalítica tenham sido os motivos pelos quais conseguimos essa conquista inesperada durante a caminhada do mestrado. No início do ano de 2008, nos deparamos com a questão que de imediato nos parecia intransponível: o comitê de ética da Universidade de São Paulo exigia a solicitação de um termo de consentimento do paciente que já não encontrávamos havia pelo menos três anos - para que a pesquisa prosseguisse. A alternativa seria desistir de um caso clínico que trazia questões fundamentais da vida humana, fenômenos avassaladores e tão atuais, relacionados às complexas relações do chamado romance familiar, a ponto de se tornarem cada vez mais presentes na mídia. Seria desapontador simplesmente engavetar o caso como se este tivesse terminado em 2005, com o fim das sessões, e não continuado a suscitar, para a analista, nos anos que se seguiram, inúmeros questionamentos. Algum novo destino precisava ser dado a tantas questões que ficaram abertas a partir deste trabalho de análise, e o mestrado seria a possibilidade de leválas para o campo teórico.

A proposta de procurar o ex-paciente e pedir-lhe a autorização foi discutida por um bom período de tempo. Mas a analista não aceitava essa hipótese por acreditar que a reaproximação e o pedido causariam uma interferência transferencial e fechariam a porta para uma possível volta de Eugênio à análise, caso ele precisasse um dia. Entramos, então, num mar de questões sobre o que é um caso clínico: O que é fato clínico? Existe a impossibilidade 
de teorizar a partir de um caso clínico? Quais são as implicações éticas de se apresentar um caso clínico?

Ao optar por seguir as questões éticas envolvidas num caso clínico, podemos nos guiar pelos exemplos de Freud, para quem é mais fácil preservar um paciente omitindo os dados mais óbvios e insignificantes de sua vida. É simples proteger a identidade de uma pessoa, mesmo revelando os fatos mais íntimos e normalmente mais bem guardados de sua mente. Em nada acrescentam ao entendimento do caso os dados reais sobre a identidade do paciente, ao passo que as cenas de auto e heteroagressões familiares que iremos discutir ao longo da dissertação surgem cada vez mais escancaradas e repetidas no cotidiano brasileiro. Omitir certas questões da vida do paciente e manter outras é outro recurso ético, na medida em que deformar ou transformar certos conteúdos pode colocar em xeque a veracidade do material trabalhado, bem como não ser o suficiente para proteger o paciente.

"A questão ética de se saber objeto de atenção privilegiada do analista não é inocente no andamento do processo analítico”, como nos lembra Mezan (1998, p. 166). E, como bem disse Freud (1912/1990b), há o risco de se perder todo o trabalho ao se escrever sobre um caso enquanto este ainda está em tratamento. Um dos argumentos que utilizamos diante do comitê de ética foi justamente o de que estávamos escrevendo após o término do tratamento e, portanto, isto não acarretaria prejuízos para o paciente. Como já foi dito, esse era um dos motivos alegados pela analista para não tentar obter o documento do paciente. Portanto, definimos que o trabalho seria uma pesquisa clínica documental pós-fato e, portanto, sem necessidade de consentimento livre esclarecido.

Um caso clínico é sempre uma produção do analista, em parte, pois é impossível reproduzir fielmente o que se passou no transcorrer das sessões entre a dupla analítica. Mesmo que o analista faça anotações imediatamente após as sessões, estará sujeito aos processos de recalque, contratransferências e transferências de seu próprio psiquismo. Eis 
uma das questões que a ciência positivista se agarra para argumentar contra a inserção da psicanálise como disciplina científica. O psiquismo, objeto a ser investigado, é, ao mesmo tempo, o instrumento que produz a investigação.

Uma análise como a de Eugênio, que transcorreu ao longo de cinco anos, com uma frequência que oscilou entre três e quatro sessões semanais, dificilmente pode ter seu conteúdo teorizado na totalidade. O material produzido pela analista, dada sua extensão e profundidade, não poderia ser esgotado nesta investigação, e esse foi outro argumento empregado ao comitê de ética. Como dissemos no início, são muitas, senão infinitas, as possibilidades de investigação de temas surgidos em uma análise como essa. Na hipótese de Fédida (1991), um caso clínico é uma teoria em gérmen, uma capacidade de transformação metapsicológica. Em outros termos, o caso clínico é construído.

No caso da nossa dissertação, evidentemente que privilegiamos certas sessões, alguns conteúdos, determinadas cenas, aqueles que tinham uma relação com o tema que estávamos interessados em debater metapsicologicamente no momento. Desta forma, construímos o caso clínico que ora apresentamos. O que, de alguma maneira, elucida para que serve um caso clínico: ou seja, não para expor a vida e a história de um determinado paciente ou para satisfazer as necessidades narcísicas de um analista, mas para ilustrar as questões sobre as quais precisamos avançar na teoria e na prática da psicanálise. E tal intuito só é possível com a observação e a experiência clínicas. Encontramos a definição de fato clínico durante nossos diálogos sobre como apresentar um caso clínico. Por definição, este é um método de observação consensual, de construção de inferências sobre a dimensão subjetiva, intersubjetiva e relacional da prática psicanalítica e sua publicação, da qual surgem as discussões sobre a clínica psicanalítica (Oliveira \& Rosa, 2001).

No artigo de Oliveira e Rosa (2001), há uma especificação de que quando os fatos clínicos encontram-se no campo da psicanálise eles precisam ser chamados de "fatos clínicos 
psicanalíticos” (p. 16). Neste sentido, Oliveira e Rosa (2001) citam uma definição de Vollmer Filho (1995) que explica essa denominação como sendo uma construção realizada por analista e analisando no interior do campo psicanalítico. A construção aconteceria a partir da comunicação de fatos ocorridos dentro e fora da sessão, como sonhos, estados afetivos, condutas, da parte do analisando, e pela experiência emocional, técnicas e teorias do analista que permitem atribuir novos significados aos fatos relatados. Portanto, um caso clínico seria a apresentação de uma série de fatos clínicos psicanalíticos e, por isso, uma produção compartilhada por ambas as pessoas envolvidas nesse processo.

Como relatar esses fatos clínicos que constituem um caso clínico é uma questão delicada. Tomamos o sentido da palavra ilustrar, a qual, conforme o dicionário Larousse (1980), significa, entre outras coisas, "esclarecer, comentar, elucidar" (p. 450), para dizer que esta é a função dos fatos clínicos que apresentaremos ao longo dessa dissertação. Esclarecer e elucidar, quando necessário, os conceitos que estamos nos propondo a estudar, que são o superego e o ideal do ego.

Para introduzir o tema do trabalho, buscamos, neste estudo, investigar estes dois conceitos. Desintricar superego de ideal do ego significa revitalizá-los como instâncias organizadoras do psiquismo. Entendemos que é na articulação destes conceitos que reside a possibilidade de fazer um debate metapsicológico para redimensionar a noção de superego, de forma a encontrar respostas para as inquietações geradas na clínica psicanalítica.

A relevância dessa revisão teórica e do debate metapsicológico a partir da clínica é a de possibilitar um avanço na compreensão do enlace dos conceitos na teoria e assim evidenciá-los como recursos à clínica psicanalítica. Partimos, então, do pressuposto de que, se houver um reequilíbrio das forças que estão em jogo nos conflitos do superego, será possível, via exercício da capacidade sublimatória, construir caminhos para a potencialidade criativa - a qual conferirá autonomia ao sujeito no sentido de reconstrução de si mesmo. 
Para dar conta do que estamos propondo, construímos a estrutura da presente dissertação em três capítulos, os quais se ocuparão do caso clínico, dos argumentos metapsicológicos e do debate teórico clínico. Apresentaremos no primeiro capítulo o caso clínico sobre o qual nos debruçaremos, causador das inquietações que levaram a esta pesquisa. No relato do caso, contaremos a história do paciente e seu intenso sofrimento com o romance familiar ao qual estava preso. Será encontrada nesse capítulo uma descrição dos sintomas do paciente, da busca dele por tratamento, dos personagens principais desse romance, da maneira como a transferência foi acontecendo e sendo trabalhada ao longo da análise e dos efeitos da análise em sua vida. Uma questão peculiar no tratamento desse paciente era a sua produção escrita, trazida por ele às sessões de análise. Por uma questão ética, já que inexiste consentimento do paciente para publicação dos seus contos, esse material não será reproduzido no corpo da dissertação, mas apenas relatado pela investigadora, que aproveitará as reflexões produzidas no curso da análise.

O segundo capítulo consistirá numa revisão conceitual do superego e do ideal do ego na obra de Sigmund Freud, tendo em vista que esse estudo teórico é que nos permitirá travar um debate metapsicológico e tecer as relações entre a clínica e a teoria, necessárias para o devir da psicanálise. As questões inevitáveis no caminho dessa investigação sobre o que é afinal o superego, e que serão abordadas neste capítulo, dizem respeito à relação entre superego e pulsão de morte, a teoria das identificações constituintes do superego e, por fim, à diferenciação entre superego e ideal do ego. A ideia de dupla face do superego, como estamos nomeando neste trabalho, existe na obra freudiana e foi a principal questão teórica que moveu a analista na condução desse tratamento analítico.

Por fim, o capítulo três ocupa-se da segunda etapa do tratamento de Eugênio, na qual surgem as questões referentes ao papel desempenhado na análise pelos contos dele, e que permitiram observar os efeitos da mesma nas escolhas do paciente. O ponto sobre os contos 
traumáticos, como nomeamos, tenta dar conta de como um tratamento que pressupõe o uso da palavra pode se beneficiar de escritos do paciente; que função tinham esses contos na vida de Eugênio e em sua análise e como foram trabalhados tecnicamente esses conteúdos a fim de favorecer movimentos no psiquismo do paciente. A partir deste momento do tratamento, no qual o traumático é historiado, é possível observar mudanças nítidas no paciente e as identificações passam a favorecer que o ideal do ego esteja a serviço das criações, evidenciando o superego benevolente como outra face dessa instância. Para finalizar o trabalho, foi preciso tratar dos elementos da análise que favoreceram esse processo de mudança nas economias psíquicas do paciente, da escuta e da confiança como alicerces de uma transferência positiva, criativa e propulsora de novos movimentos. 


\section{RETRATOS DE UM ROMANCE FAMILIAR}

\subsection{Os personagens e as vozes do superego}

Era início da primavera quando um rapaz, vestido formalmente com um terno de bom corte, sem conseguir esconder a própria ansiedade, chega para um primeiro encontro com a analista. Tenta aparentar ser um homem bem-sucedido, de seus trinta e poucos anos, com uma fala bem articulada e formal. Senta-se e vai logo dizendo que, em sua opinião, não precisaria se tratar, mas que buscou a análise por insistência da namorada. Permanece com esta postura durante uns cinco minutos de sessão, durante os quais relata que o motivo do pedido da namorada é o namoro conturbado dos dois, com muitas brigas, instabilidades emocionais dele e cobranças da moça para que fosse menos ciumento.

Logo começa a se despir da carapuça de homem forte e bem-sucedido e, muito rapidamente, aparece como um adolescente muito angustiado e atormentado com seus pensamentos. O jovem tinha apenas dezenove anos e cursava o primeiro ano da faculdade de direito. Era magrinho e o terno ficava bastante largo em seu corpo. Segue dizendo ser bastante ciumento, bravo, inseguro, mas também carinhoso, afetivo, sentimental e muito pouco racional. Comenta que a namorada achava-o parecido com o pai e que ele havia percebido que, sim, era igual ao pai, mas que sempre quis ser diferente dele e que, se não mudasse algumas coisas, ficaria como o pai. Um silêncio pesado tomou conta do ambiente por alguns minutos.

Até aquele momento, a analista, também jovem e com poucos anos de experiência clínica, escutava sem imaginar o que pudesse estar por vir. O silêncio continuou até que Eugênio - como vamos chamar o paciente - indaga sobre por onde deveria começar. A analista responde que ele seguisse por onde quisesse, e assim foi. Eugênio admite ser difícil aceitar a ideia de que precisa se tratar, mas que, no fundo, sabia da necessidade do tratamento. 
O jovem muda o tom de voz e começa a relatar uma história cujo desdobramento só saberíamos alguns anos depois.

Os pais de Eugênio separaram-se quando ele tinha apenas 10 anos. Nesse primeiro encontro, o relato é de que nenhum dos pais havia se casado novamente, o que, ao longo do tratamento, é desmentido no momento em que uma cena trágica e traumática da vida do pai é contada. Desde que o pai saiu de casa, o menino passou a dormir na cama com a mãe, o que ocorreu diariamente até ele completar 16 anos de idade. Nesse núcleo familiar, passaram a viver ele, a mãe e um irmão mais novo, não menos problemático, por quem Eugênio sentia-se responsável. Desde a separação dos pais, o paciente e o pai não mantinham uma relação muito próxima, pois esse filho mais velho recriminava as atitudes do pai e dizia querer ser o oposto deste, embora em algumas coisas o pai fosse o modelo de ideal do que pretendia ser. Esse conflito anunciado rendeu bons anos de análise e muito sofrimento ao paciente.

O pai foi descrito como um homem complicado, genioso, instável, autoritário, depressivo e que estourava por pouca coisa, além de não conseguir conviver por muito tempo com ninguém. Também surgiu uma faceta de um pai brilhante, tido por este filho como um profissional bem-sucedido, inteligente, dedicado ao trabalho e reconhecido. O pai é concursado público, sendo que exerce um cargo do alto escalão do direito, como também havia sido o avô paterno.

A família paterna é bastante comprometida: esse avô, que também era da área do direito, suicidou-se pouco tempo depois da separação dos pais de Eugênio. A versão criada pelo paciente é de que assim que os pais dele se separaram, o pai saiu de casa, foi de férias para Miami, e a avó paterna pediu separação poucos dias depois. O avô, percebido pelo menino como um homem diferente do pai, não teria suportado o pedido de separação da avó, que era "louca", nas palavras do neto. Pelo relato, além da avó louca, Eugênio dizia ter uma 
"tia maníaco-depressiva" e outra tia "fora do ar" e, que, portanto, era compreensível que o pai fosse complicado.

A mãe era descrita pelo rapaz como "uma santa", mulher que abdicou da profissão quando casou porque a profissão do pai exigia que ele fosse transferido de cidade, de tempos em tempos, pelo interior do estado. Dessa forma, ela acompanhava o marido, cuidava da casa e dos filhos. Não faz comentários sobre a família da mãe, mas diz que os pais brigavam muito, o pai discutia e gritava muito com a mãe e ela aguentava tudo calada. Essa mulher não refez a sua vida após a separação, não teve novos romances exogâmicos e continuou vivendo da pensão do marido. Ao longo do tratamento, Eugênio nunca mencionou se a mãe tinha amigas e buscava atividades de lazer. Era sempre citada como estando em casa, cozinhando e limpando tudo para os filhos. Sobre isso, Eugênio não tinha críticas, parecendo não perceber o isolamento e a falta de vitalidade dessa mulher.

O paciente é um rapaz inteligente, muito culto, estudioso e interessado por várias áreas do conhecimento, como filosofia, direito, literatura e línguas estrangeiras. Fazia aulas de italiano e inglês, estagiava num escritório, frequentava aulas da faculdade. Era um rapaz que se dizia tímido, envergonhado para falar, com expressão muito triste, bastante inseguro, quase não saía de casa para viver uma vida de adolescente universitário. Não participava das festas da turma da faculdade, não bebia, apenas estudava e namorava. Seu namoro o atormentava. A moça era três anos mais velha e já tinha experiência anterior de namoro, o que o incomodava bastante, pois, segundo ele, a jovem jogava na sua cara que era mais experiente e que ele era muito problemático.

O tema da herança foi presente por muito tempo no tratamento. O paciente dizia-se temeroso de "ter herdado as características do pai" e ficava muito apreensivo com o medo de uma repetição. Isso o fazia pensar em mudar de curso universitário, pois o avô havia sido bacharel em direito, o pai também, como se fosse o curso de direito o sinistro que pudesse 
desgraçar a sua vida. Depois de alguns meses, Eugênio chega a uma sessão dizendo que precisava muito contar uma coisa que era difícil para ele falar. Chora bastante e diz que o pai tinha tido um acidente de carro e atropelado um homem que morreu. Nessa ocasião, pede para deitar no divã, assunto no qual não havia tocado desde as combinações iniciais, que eram a de usar o divã quando se iniciasse a análise com três sessões semanais.

O paciente relata que o pai é alcoólatra e que, certa vez, ele e um primo da idade dele, a quem chamaremos de Otávio, estavam na casa do pai jantando e tiveram uma discussão causada pelo fato de Eugênio chamar o pai de alcoólatra. Mas essa introdução do tema foi mais importante pelo aparecimento desse primo na história do que propriamente pela cena da briga com o pai. Esse primo é sobrinho do pai, filho de uma irmã do pai e, sem que analista e analisando pudessem imaginar, ainda viria a ter um papel crucial na análise de Eugênio. O fato é que, nesse momento, o paciente se põe a contar que o pai tinha se casado novamente, com uma mulher que o filho define como "vagabunda que só queria o dinheiro do pai". Esse segundo casamento foi realizado sob o regime de comunhão total de bens, mas, segundo Eugênio, o problema não era esse, mas sim que o pai havia colocado alguém no lugar dele. Ao falar essa frase, o paciente não escuta o que diz. Ao ser questionado pela analista sobre como que o pai poderia colocar alguém no lugar dele, o rapaz confirma o que disse repetindo que havia colocado alguém no lugar deles, de Eugênio e o irmão, não percebendo seu ato falho.

Enquanto se queixava do casamento do pai, Eugênio não percebia o lugar em que havia se colocado nessa relação com o pai, num lugar homossexual e incestuoso que ele reproduzia atualizadamente na relação com a namorada. Conta que esse casamento do pai era cheio de brigas, idas e vindas, exatamente como descrevia seu namoro com Eduarda, como chamaremos a namorada. Além dessa reprodução, Eugênio também estabelecia com esta 
moça um modelo de relacionamento no qual se sentia humilhado e depreciado por ela, queixas que dirigia também ao pai.

Eugênio segue contando que, quando o pai separou-se dessa segunda esposa, teve de dividir todos os bens com ela, inclusive o que viria a ser de Eugênio e do irmão. A sequência de atos falhos do paciente segue quando, ao falar da herança que um dia seria dos filhos, se equivoca chamando o irmão de filho dele, confirmando o lugar que o paciente ocupava na fantasia, ou seja, de ser a mulher do pai e ter um filho com este. Esse relato desembocou mais tarde numa questão complicada sobre a sexualidade de Eugênio. Somente meio ano depois de iniciar a análise é que ele pôde falar que não conseguia manter uma ereção nas relações sexuais com Eduarda.

Voltando ao pai, quando este se separou do segundo casamento, como conta o paciente, passou a beber muito mais do que já fazia normalmente. O episódio do atropelamento ocorreu da seguinte forma: o pai de Eugênio alugou uma cabana num parque de recreação, como eles chamavam, para passar o fim de semana; na madrugada de sábado, completamente embriagado, resolveu pegar o carro e ir até a cidade falar com a segunda exesposa e no trajeto atropelou um senhor, que veio a falecer. O pai de Eugênio acabou preso na hora, pois estava embriagado, sem documentos, armado, e os policiais não acreditaram que ele era quem dizia ser, um desembargador.

Essa cena foi muito traumática para Eugênio. Ele conta isso aos prantos, primeiramente porque achava que, aos 16 anos, não deveria estar numa delegacia, de madrugada, tentando tirar o pai da cadeia, enquanto seus amigos faziam festa. Contudo, o mais traumático para nosso jovem rapaz foi perceber que a cena parou ali nesse "acidente", entre aspas, como ele diz, para não terminar numa cena pior, pois, segundo sua suposição, a intenção do pai ao sair de madrugada, bêbado e armado, era dirigir-se à casa da ex-esposa para discutir e possivelmente a matar, num ímpeto de descontrole e raiva. Diante desse 
raciocínio, Eugênio toma o pai como um homicida e essa é a questão que mais o fere. $\mathrm{O}$ avô suicidou-se, o pai cometeu um homicídio, pois assim foi julgado e condenado pela Justiça. $\mathrm{O}$ que seria dele, então?

Quando Eugênio comunicou, no final do primeiro mês de tratamento, que não manteria as três sessões semanais porque o pai negou-se a pagar, e ele só conseguiria arcar com o valor de um horário, consideramos a possibilidade de interromper o tratamento e retomar quando ele estivesse organizado para fazer sua análise. Não foi o que ocorreu, e, certamente, a decisão de mantê-lo em tratamento com uma sessão trouxe alívio e foi muito importante para que o rapaz pudesse sentir que havia um espaço só dele e percebesse sua necessidade de tratamento. Depois dessa sessão em que Eugênio conta do "acidente do pai", a analista passou vários dias pensando se deveria ou não ter liberado o divã quando ele solicitou. Mas manteve-se firme na combinação inicial, o que foi crucial para o paciente mobilizar-se e conseguir aumentar sua frequência. Assim, conforme o combinado, ele pôde ir para o divã.

\section{2 - Os contos}

Na época em que o homicídio culposo do pai foi narrado na análise, o sofrimento de Eugênio intensificou-se muito e ele resolveu que precisaria dar um jeito de ganhar mais dinheiro para pagar suas três sessões de análise. Sai do estágio que estava fazendo e prepara-se para um concurso público. Começa a trabalhar ganhando um bom salário, o suficiente para pagar sua análise e manter suas outras despesas. Eugênio conta que tinha o hábito, quando mais adolescente, de escrever contos, geralmente depois de situações como a da noite em que passou na delegacia com o pai. Passou a trazer alguns contos escritos na época do suposto acidente, lia-os em sessão e depois entregava as cópias para que a analista guardasse esse material. 
Esse foi um momento importante da análise, porque, por meio dos contos que trazia, foi possível acessar temas, conteúdos e sentimentos sobre os quais ele tinha muita dificuldade de falar no tratamento. Enquanto Eugênio lia os contos, a analista, em silêncio, escutava-o, e, ao terminar, convidava-o a pensar sobre o que havia escrito, usando a técnica da interpretação dos sonhos, descrita por Freud no capítulo VII da Interpretação dos Sonhos. Questionava o paciente sobre o que havia despertado a escrita por tal tema, o significado dos elementos que apareciam em cada conto e, assim, ambos começaram a ter acesso às fantasias inconscientes, aos temores e atrapalhações identificatórias. Em seguida, Eugênio deita-se no divã e começa a poder escutar-se mais e a pensar nas posições que ocupava nas relações e nos seus destinos.

Inicialmente, os contos, todos quase autobiográficos, eram sobre angústia, o pai, religião, e sempre escritos em momentos tensos e muito intensos para o paciente. Por meio desses contos, ficamos sabendo da íntima relação de Eugênio com a religião. Ele diz que inicialmente não falava desse assunto por medo de a analista o recriminar e tirar dele algo que por muito tempo foi seu esteio. Ao aumentar a frequência da análise, diz que agora já não precisava mais desse recurso da religião e que poderia falar sobre isso.

Ao deitar-se no divã, Eugênio surpreende-se com a liberdade de poder falar. Conta, quase como numa confissão, que desde os 16 anos pensava em ser padre e que, após entrar na faculdade, conheceu uma pessoa que o convidou a participar de um movimento da Igreja Católica. Passou a frequentar o Opus Dei. Lá ele tinha um orientador espiritual ao qual precisava contar semanalmente tudo o que fazia, inclusive os detalhes de seu namoro. Eugênio diz que, enquanto comparecia à análise uma vez por semana, manteve esse contato semanal com o orientador espiritual porque ainda se sentia muito sozinho para resolver seus problemas e estava muito confuso. E que, na medida em que fomos tratando outros assuntos na análise, ele pensava sobre a religião também. Diz que, mesmo com uma sessão por 
semana, o tratamento o ajudava muito e que abriu mão da orientação espiritual quando sentiu que tinha um espaço maior para falar e pensar sobre si.

Ser padre ou não ser padre, pelo relato do paciente, foi uma questão constante por anos e, principalmente, no primeiro ano do tratamento analítico. Até que ele percebeu que, sendo padre, não estaria livre de repetir as tragédias familiares. A analista, durante esse primeiro ano de análise, sabia que o assunto da religião era deixado de fora das sessões, mas, assim como diante de outras especificidades desse tratamento, manteve-se em silêncio, até que Eugênio incluiu o assunto na análise. Essa postura ele diz ter sido fundamental, que se analista tivesse se apressado e o questionado sobre o tema ele não sabe se não teria largado o tratamento.

Talvez tenha sido esse o grande aprendizado que a analista teve com Eugênio: saber esperar o tempo dele e escutar em silêncio. Houve muitos momentos de dor, choro, medo e sofrimento. Junto com o assunto da religião, são construídas as condições para analisarmos os assuntos ligados à sexualidade genital do paciente. Ele conta que foi muito difícil a experiência de não ter mantido a ereção nas primeiras tentativas de transar. Por um tempo, o conflito entre ser padre e não ser padre foi a justificativa encontrada para explicar sua dificuldade com a namorada.

Quando questionado sobre como surgiu a ideia de ser padre, ele diz que desde os 7 anos, principalmente depois que o pai saiu de casa, até os 16 anos, dormia na cama da mãe e que um dia acordou assustado por conta de uma ereção. Passou, então, a dormir separado da mãe. Percebe que a dificuldade de transar com a namorada estava ligada à excitação que sentia pela mãe, que saiu da cama dela para a cama da namorada, que seria impossível mesmo conseguir transar. Em seguida, surgiu o tema da homossexualidade. Certamente que esse rapaz tinha uma relação muito ambivalente com o pai, o que denunciava fantasias homossexuais que interferiam muito no seu cotidiano. Isso era observado pela passividade com que ele se colocava diante da namorada, do pai e da própria vida. Mas a alta temperatura 
entre ele e a mãe mostra uma relação muito mais íntima e quente do que suporta um vínculo afetivo entre mães e filhos e denuncia que toda a história com o pai estava a serviço de seduzir a analista para uma neurose obsessiva clássica, de amor e ódio com o pai, deixando a mãe protegida dentro dele.

A essa altura do tratamento, Eugênio passa a queixar-se do seu corpo, de ser muito magro e fraco. Matriculou-se numa academia, começou a mudar suas vestes e parecer mais condizente com sua idade. Na medida em que avançavam os questionamentos sobre sua relação de submissão com o pai e suas dúvidas sobre ser homossexual, também surgia a ideia de largar a faculdade de direito e fazer outro curso universitário. Apesar de o paciente trazer assuntos e cenas que envolviam a homossexualidade, era perigoso acreditar que esse fosse o único ou o principal ponto dessa análise e esquecer a relação com a mãe. Exemplos de brincadeiras sobre ser gay eram bem presentes entre o primo Otávio e o pai do nosso paciente. Nessas horas ficava mais fácil discriminar que ele estava falando da homossexualidade de outros dois homens e não da dele e as interpretações ocorriam no sentido de mostrar a Eugênio o desejo de ser amado pelo pai e que esse pai o ensinasse a ser homem, e não o desejo de transar com outro homem.

$\mathrm{Na}$ medida em que esses assuntos avançavam, o namoro com Eduarda foi ficando em segundo plano e temas como festas, academia, mulheres começaram a surgir. O namoro chega ao fim e Eugênio começa a experimentar uma vida de jovem que ele ainda não conhecia, de ter amigos, fazer festas, viajar, ficar com garotas. Numa fase seguinte, começou a descrever as moças por quem se apaixonava como sendo todas com características semelhantes: loiras, não muito altas, entre outros traços. Essas moças, idealizadas, o levavam ao choro e à decepção. Aos olhos da analista eram evidentes o apaixonamento transferencial e a tentativa de erotização do vínculo analítico; aos olhos do paciente isso não era claro. Tentativas de conquistar a analista aconteciam discretamente. Ele voltou a escrever textos, nesse momento 
já não mais com uma função catártica: trazia os temas de maneira mais elaborada, descolados das suas experiências, porém sempre assuntos que o intrigavam.

Os primeiros contos incluídos na análise foram trazidos impressos e confiados à analista, para que os guardasse até que ele próprio pudesse se encarregar disso. Nessa segunda fase, Eugênio já não precisava mais trazer os textos, podia falar sobre os conteúdos e refletir a respeito. Chegava sempre contente para a análise, certamente já mais aliviado por perceber que não precisava ter o destino do pai e do avô, mas também pelo seu encantamento com a analista. Quando indagado sobre o que o atraía nessas moças com características físicas que lembravam às da analista, Eugênio começa a perceber a semelhança. Passa a se angustiar com a ideia de que pudesse encontrar a analista nas festas à noite, e em como seria esse encontro, já que aparentemente as idades de ambos não eram tão discrepantes.

Ainda que as fantasias de Eugênio a respeito dessa transferência fossem analisadas, seu nível de angústia aumentou consideravelmente. Houve alguns atrasos, algumas faltas, até o momento em que a analista precisou mais diretamente garantir a ele que entre os dois nada se passaria além de ele falar e ela escutar. E que a intensidade de sua angústia com a proximidade com a analista não tinha a ver com uma paixão pela analista, mas com outra experiência de intimidade excessiva que ele já havia tido com uma mulher com quem isso não deveria acontecer. Isso o acalmou um pouco, mas a fantasia de uma intimidade com a analista ainda o assustava. Foi preciso uma nova intervenção da analista, dizendo que ali ambos não tinham intimidade, mas, sim, proximidade, e que essas eram duas coisas diferentes.

Esse momento foi bastante complicado para ambos, a analista tentando segurar a transferência erótica que se esboçou, e se tornara uma forte resistência ao tratamento, e o paciente tentando suportar a angústia que isso lhe despertava. Obviamente que essa intensidade não tinha a ver com a pessoa da analista, mas com o período em que o paciente dormiu com a mãe, na pré-adolescência e parte da adolescência. A ideia de excitar-se com sua 
mãe lhe era muito desconfortável e apavorante, mas começava a se encaixar no raciocínio de como as coisas se passaram com ele para que pensasse ser homossexual mesmo sabendo que não gostava de homens, e sim de mulheres. Acabou por recordar uma cena com a mãe cuja lembrança lhe causava certo terror.

Certa vez, Eugênio estava saindo do banho, despido como parecia ser o hábito da casa, onde mãe e filhos trocavam de roupa ou andavam nus livremente, e a mãe olhou bem para o filho e comentou que este devia enrolar-se numa toalha para ir do banheiro até o quarto. Quando ele indaga por que ela havia feito esse comentário, ela responde a ele com outra indagação, questionando o filho se ele não pensava que ao vê-lo nu ela não poderia se excitar. Nessa época ele estava com 16 anos e, segundo o paciente, este foi o fato que, somado ao de acordar com ereção ao lado da mãe, o levou a parar de dormir na cama da mãe e a começar a dormir sozinho.

A sequência dos acontecimentos começa a clarear para Eugênio: sair da cama da mãe, pensar em ser padre, começar a namorar Eduarda e não conseguir manter ereções e, por fim, duvidar de sua masculinidade construindo a fantasia de ser homossexual. Surge uma nova e tumultuada fase na sua vida. Ao lembrar-se desse episódio, desespera-se, não se conforma como uma mãe pode dizer isso a um filho. Começa a ver que a mãe não era a santa que ele imaginava e que, se nem mãe nem pai conseguiam dar-lhe a atenção de que precisava, ele ficava desamparado. A partir da vivência desse sentimento, uma nova organização psíquica de Eugênio foi possível.

A ideia de sair da casa da mãe e ir morar sozinho foi constante nos primeiros seis meses daquele ano. A essa altura da análise, o paciente já estava na metade da faculdade de direito. Conseguiu convencer a mãe e o pai de que, se dessem diretamente a ele, e não à mãe, a parte da pensão a que lhe era de direito, somando ao que ele ganhava no trabalho seria capaz de gerenciar sua vida, pagar suas contas, morar sozinho. E assim fez, procurou apartamento 
para alugar dentro de um orçamento que não comprometesse suas sessões de análise, e rapidamente mudou-se da casa da mãe.

Pouco tempo depois que Eugênio saiu de casa, uma nova tragédia se abate sobre a família do paciente. Dessa vez, as coisas se complicam muito, um episódio grave acontece envolvendo o primo, que já citamos acima, Otávio, com quem Eugênio havia crescido. Tinham apenas um ano de diferença de idade, e o primo se envolve num homicídio. Esse primo é filho de uma tia, irmã do pai, e, segundo o paciente, era o melhor amigo dele na adolescência. Seguidamente esse rapaz aparecia nas sessões por meio dos relatos das festas, viagens, paqueras de Eugênio e brincadeiras sobre homossexuais, entre o primo e o pai de Eugênio, que o incomodavam.

\section{3 - Os efeitos de uma análise.}

Esse capítulo do romance familiar inicia com o sumiço de uma tia dos rapazes. O pai tinha três irmãs, uma era a mãe de Otávio, outra a advogada que tirara o pai da cadeia na noite do atropelamento, e a terceira era esta irmã do pai que havia sumido. Com cerca de 45 anos, ela nunca havia casado e tido filhos. Essa tia tinha uma rotina estabelecida há anos, que consistia em ir à casa da mãe, avó dos rapazes, de manhã cedo, e, em seguida, tomar café da manhã no hotel da esquina. Ela não aparecia em nenhum desses lugares havia três dias. A família decide acionar a polícia, que passa a procurá-la em hospitais, necrotérios, praças e não consegue nenhuma notícia. Depois de uma semana de sumiço, o pai de Eugênio contrata um detetive particular. O profissional pede uma semana para solucionar o caso. Era uma quinta-feira à tardinha quando Eugênio chega para a sessão contando que na manhã do dia seguinte terminaria o prazo do detetive e uma reunião tinha sido marcada com toda a família às $10 \mathrm{hs}$.

No início desta tarde de quinta, o pai de Eugênio liga solicitando que quando ele saísse do trabalho passasse no seu escritório, pois precisavam conversar seriamente. Ao dizer que 
tinha análise e não iria, Eugênio se depara com uma reação enérgica do pai, dizendo se tratar de um assunto muito sério. Eugênio então sai um pouco mais cedo do trabalho e vai até o pai, que revela a suspeita do detetive de ter sido Otávio o responsável pela morte da própria tia. Até aquele momento, o detetive ainda não havia encontrado o corpo, mas trabalhava com a hipótese de dois lugares, os quais seriam investigados naquela tarde. Se o corpo estivesse em um desses lugares, esta seria a prova de que tinha sido o primo. $\mathrm{O}$ detetive ainda estava tentando uma confissão de Otávio, sem sucesso.

Eugênio sai desse encontro com o pai muito perturbado, diz para o pai que isso não é possível, que conhece bem o Otávio e que este seria incapaz de matar uma mosca. Que o primo havia sido o melhor amigo dele nos últimos cinco anos, e era seu ídolo. Quando a analista repete a conjugação verbal dele, em tom de indagação, enfatizando "era (?)", ele começa a chorar muito e diz à analista que se isso for verdade terá de repensar tudo, quem ele é, as pessoas com quem se dá, as amizades, os conceitos, os valores de vida, que seu mundo cairia e ele iria desabar. Diz que, durante esses dias, Otávio era a pessoa mais preocupada com o sumiço da tia. Eugênio conta ainda que Otávio era igual a ele. Quando questionado "igual no quê?", o paciente responde que o primo havia passado por várias desgraças familiares. Aos 16 anos, Otávio e o pai estavam mergulhando no Caribe, em férias com a família, quando o pai apareceu morto. A história é que ambos mergulhavam juntos e ventava muito, e então o filho resolve sair do mar e deixar o pai. Dez minutos mais tarde, o corpo do pai apareceu boiando.

No dia seguinte, a analista recebe uma ligação muito cedo da manhã, solicitando uma sessão extra o mais breve possível, o que acontece no final da manhã. O paciente chega transtornado, dizendo que o corpo da tia havia sido encontrado e que o primo confessara que a tinha matado. O motivo seria, segundo o primo, uma dívida de 12 mil reais que tinha com a tia e que esta vinha cobrando. A história contada pelo primo é realmente assustadora, não era 
de se estranhar que Eugênio estivesse apavorado. Consta que o primo foi até o hotel em que a tia costumava tomar café da manhã, tomou café com ela e em seguida a levou até a casa dele, num condomínio de luxo da cidade, com a desculpa de que a pagaria em espécie. Ao chegar, o primo matou a tia afogada na piscina e escondeu o corpo num armário até que anoitecesse. Naquela semana, a mãe do rapaz não estava na cidade e ele se encontrava sozinho. Durante a noite pôs o corpo da tia no porta-malas do carro e o largou num matagal, à beira de uma estrada.

O detetive localizou o corpo e arrancou a confissão do jovem. A tragédia abateu toda a família e Eugênio se desespera ao constatar que o destino havia chegado à terceira geração da família, com um agravante: agora se tratava de um homicídio doloso e não mais culposo, como havia sido o do pai. Na semana seguinte, uma nova reunião familiar é marcada, com a avó e as outras duas irmãs do pai ainda vivas, sendo que uma delas é a mãe de Otávio. Curiosamente, essa reunião aconteceria no mesmo horário em que Eugênio tinha sessão de análise e o pai, já bêbado, liga para ele pedindo que comparecesse à reunião representando-o, uma vez que estava em casa bebendo e não poderia sair dirigindo. Eugênio chega à sessão dizendo que esse pedido do pai foi muito angustiante, pois a tendência dele era ir, mas que pensou muito ao longo do dia nas coisas que tratávamos na análise, de que ele não era o pai, e não precisaria se envolver nos caminhos que tradicionalmente a família se envolvia. Diz que naquele dia ficou muito claro para ele qual seria sua saída: ou iria à reunião familiar e ficaria fadado a repetir em sua vida algumas dessas tragédias, escolhendo pela repetição, ou não compareceria à reunião e poderia, assim, ir à sua sessão de análise, o que significava escolher um destino radicalmente oposto ao da família. Felizmente, assim aconteceu. Eugênio ligou para o pai dizendo que esse assunto não era da competência dele, que o pai é quem deveria ir, já que a reunião era entre a avó e seus filhos. Que ele não queria saber dos problemas da família e que tocaria a sua vida. 
A frequência de quatro sessões por semana, que já estava em curso, foi fundamental para que o paciente sustentasse essa decisão. De fato, ele passa a não se envolver mais com os problemas da família. Escuta os comentários, sofre, mas não se ocupa das demandas do pai. Leva um tempo ainda falando sobre a sua relação com o primo, algumas pequenas transgressões que ambos haviam feito juntos aos 14, 15 anos. Sofre quando o primo é preso e julgado. Fica no ar uma suspeita de que o primo teria matado o pai no tal mergulho, sete anos antes. Mas a avó e as outras tias, uma delas a mãe de Otávio, resolvem não investigar essa hipótese.

Eugênio passa por um período de muito sofrimento, de muitos questionamentos sobre o que quer para si no futuro e com uma certeza: de que não iria repetir a história trágica de sua família. Diz que sempre se imaginou como um homem bem-sucedido, de grandes realizações profissionais, mas que, hoje, pensa que se conseguir casar, ter seus filhos e viver feliz com uma família sem repetir as tragédias, será um homem de grandes feitos. Revê o lugar que ocupa atualmente na família e decide que vai seguir um caminho próprio, distinto do deles ainda que não gostem. Nesta mesma época, um livro de contos que Eugênio organizou é lançado, o que o deixa radiante e com a sensação de que podia seguir seu próprio caminho. Começa a trabalhar num novo estágio, em outro ramo do direito, além de continuar a se dedicar a um trabalho de pesquisa com uma professora muito bem-sucedida no ramo da advocacia. Relação que lhe rende um convite para advogar num dos escritórios desta professora, em outro estado.

Eugênio começa a sentir-se feliz com a possibilidade de fazer escolhas sobre o que quer para sua própria vida. Consegue falar sobre sua opção pelo direito e pensar que pode, sim, ter uma bela carreira sem ser como o pai e o avô. Começa a gozar de independência, convida amigos para irem ao seu apartamento, sai com diferentes garotas, visita a mãe duas ou três vezes por semana, começa a ter um diálogo com o pai, que, segundo ele, se dá de 
homem para homem - pois não se submete mais, pode se posicionar, dizer o que pensa e se sentir respeitado pelo pai. Com tantas descobertas sobre si, Eugênio se dá conta do quanto ele mesmo se colocava em situações nas quais ele dizia que acabava sempre "tomando no cu", e começa a se questionar. "Tomar no cu" e "ser homem" são coisas opostas para Eugênio, e este assunto passa a tomar grande parte das sessões. Um questionamento profundo, acompanhado por frustrantes e diversas experiências com mulheres segue por quase todo o ano seguinte de análise. Eugênio viaja com os amigos no verão e diz ser a primeira vez que sente que começa a deixar de ser um "piá que toma no cu" para virar um homem. Em junho daquele ano, se apaixona por uma colega da faculdade, com quem começa a ficar e em seguida inicia um namoro que o satisfaz e que persistiu até quando a analista teve notícias.

O ano seguinte é um ano de muita produção para Eugênio na análise e, em setembro, ele chega numa sessão dizendo que estava fazendo um ano que havia lançado o seu livro de contos. Pergunta se deu um exemplar à analista e esta responde negativamente. Fica muito impressionado, se perguntando por que não havia dado um livro à analista. Quinze dias depois, entra Eugênio com um livro e o entrega à analista, dizendo que escreveu uma dedicatória, que diz o seguinte: "Receba este presente como testemunho de minha gratidão e do meu afeto. É um pouco do que construí no centro do labirinto e que ora trago à Ariadne que me conduziu nesta fabulosa empreitada."

Deita-se no divã e diz que pensou bastante no porquê de não ter dado o livro à analista quando ele foi lançado. Que dar o livro com contos escritos durante a análise significava que estaria podendo dar algo que construiu, e construiu neste espaço. Fala que quando publicou o livro ainda sentia que precisava muito da análise e temeu que a analista pensasse, naquela época, que ele já poderia terminar o tratamento. Mas que agora ele quer conversar sobre isso, pois se sente pronto e com vontade de caminhar com as próprias pernas. Conclui que podia dar o livro porque ele já podia ir embora. 
Combinamos de seguir conversando sobre o assunto. Eugênio passa a fazer uma avaliação dos seus anos de análise. Percebe os movimentos que fez, os recursos que construiu, e constata que hoje sabe quem é e do que é capaz. Quando questionado sobre que recursos são esses, lembra que quando chegou era muito diferente. Que não reconhecia a necessidade de se tratar e pensava que havia duas saídas para ele: ser padre ou se matar. Que tinha um namoro conturbadíssimo, vida sexual insatisfatória, era completamente dependente emocionalmente da mãe e financeiramente do pai, não tinha muitos amigos, não saía. Nesse dia, Eugênio fala abertamente sobre as tantas vezes que pensou realmente em se matar. Conta que quando pensava nisso, lhe ocorria ir até um viaduto muito alto que fica sobre uma avenida movimentada da cidade, do qual, se ele se jogasse, obviamente iria morrer. Conta que não falava desses pensamentos porque eram intensos e frequentes e que ele temia falar na sessão e, ao sair, tentar se matar. Mas que agora já podia falar disso porque tem certeza de que não é o que ele quer.

Eugênio afirma que seus planos são viver, ter filhos, continuar escrevendo. Diz que sabe que um dia será necessário voltar para a análise, mas que, até lá, ele mesmo pode pensar e refletir sozinho, e que certamente a voz da analista ecoará dentro dele por muitos anos. Diz sentir-se satisfeito com o que fizeram juntos na análise. Teme sentir saudades, mas diz saber que pode voltar sempre que precisar. Eugênio estava com a formatura do curso de direito marcada para início do mês de janeiro, e decidido a fazer um concurso para o Ministério Público Federal, área do direito com a qual se envolvera nos últimos dois anos de análise e da qual passou a gostar muito, já que não era sua incumbência julgar e dar sentenças. Combinamos que as sessões seguiriam até a véspera do Natal daquele ano, quando terminaria formalmente sua análise. Dia 23 de dezembro, analista e paciente se despedem e Eugênio parte para escrever os novos romances de sua vida. 


\section{SUPEREGO E IDEAL DO EGO: ARGUMENTOS TEÓRICOS PARA UM DEBATE METAPSICOLÓGICO A PARTIR DE UM CASO CLÍNICA.}

\subsection{O superego é um destino inexorável?}

“Eu não sei nem por onde começar. Na verdade eu acho que eu não preciso me tratar, eu vim mais porque a minha namorada me fez prometer que eu me trataria... Eu até acho que eu tenho problemas. Na verdade, eu tenho muitos problemas, mas não acho que as coisas são só de um lado e que só eu seja culpado. Ontem mesmo a gente brigou, mas ontem eu acho que eu tinha razão. Ela diz que eu sou muito ciumento e eu sou, mas ontem eu tinha razão. É que na verdade eu sou muito sentimental e pouco racional. Ela diz isso de eu ser ciumento, bravo, mas eu sei que tudo, tudo que diz respeito a sentimentos é comigo. Eu sou ciumento, bravo, impulsivo, sensível, frágil, inseguro, carinhoso, afetivo, tudo é muito pouco racional. Eu não consigo ser racional para quase nada. . . . Esses dias ela disse que eu sou parecido com o mеи pai, que eu sou igual a ele e eu sempre achei que fosse o oposto dele e, de repente, eи me dei conta de que se eu não mudar algumas coisas eu vou ficar igual a ele mesmo." (Eugênio).

Nos primeiros minutos da entrevista inicial, Eugênio apresenta duas grandes questões que permearam toda a sua análise e que serão debatidas nesta dissertação. A primeira diz respeito à sua declaração de culpa, que imediatamente nos remete aos pensamentos das fantasias incestuosas e ao medo da castração, do complexo de Édipo infantil, embora o paciente não tivesse consciência alguma sobre o crime que inconscientemente acreditava haver cometido; a segunda refere-se ao temor de assemelhar-se ao pai, o que nos encaminha para o campo da 
ideia de destino. A afirmação de que a impressão de um destino maligno é expressão da compulsão à repetição, e que esta é anterior ao princípio do prazer que domina os processos de excitação do psiquismo, é encontrada em Além do Princípio do Prazer, texto no qual Freud (1920/1990) desenvolve a noção até então desconhecida da pulsão de morte. Encontramos ecos dessa passagem psicanalítica na fala do jovem rapaz, que enunciava o temor de um destino terrível, submetido ao efeito da pulsão de morte.

Ao postular a existência de uma pulsão de morte, Além do Princípio do Prazer (Freud, 1920/1990) marca uma grande virada na teoria psicanalítica e a construção de uma nova teoria das pulsões. A terceira dualidade pulsional passa a consistir na contraposição da pulsão de vida x pulsão e morte. Essa mudança desembocará poucos anos depois em um novo modelo teórico do aparelho psíquico, chamado de segunda tópica ou teoria estrutural do aparelho psíquico. Uma das justificativas para a mudança na teoria pulsional é que, até aquele momento, Freud não tinha uma teoria da agressão. O polêmico texto de 1920(/1990) é baseado em Projeto para uma Psicologia Científica (Freud, 1895/1990) e é alvo de muitas divergências teóricas que permitiram o surgimento de outras teorias e ainda geram discussões como a que estamos propondo nesta dissertação.

Entendemos, a partir dos fatos clínicos que serão apresentados, a noção de destino como uma compulsão que implica a descarga primeira de algo desligado, à que Freud (1920/1990) atribuiu uma característica não somente de um quadro clínico - diferentemente da noção de repetição transferencial como fenômeno clínico presente em Recordar, Repetir e Elaborar (Freud, 1914/1990b) - mas à criação do conceito de repetição como força de um ataque pulsional. Esta premissa, que marca a virada teórica, provoca mudanças, também, na técnica freudiana. Isto porque foi introduzido um ponto de vista econômico que, segundo o próprio Freud (1920/1990), somado aos pontos já mencionados em sua obra - o ponto topográfico e o dinâmico - forneceria a mais completa descrição do que é concebido por ele 
como a metapsicologia psicanalítica. A nova teoria pulsional traz em seu bojo a noção de energia vinculada ou ligada e energia móvel ou desligada, permitindo pensar que, antes mesmo do princípio do prazer reger o psiquismo, há uma compulsão à repetição que está relacionada a esta energia desligada, como expressão da pulsão de morte.

A proposição de que o objetivo de toda vida seria a morte (Freud, 1920/1990) marca a existência desse algo no psiquismo que estaria mais além do princípio do prazer. Ou, melhor dizendo, aquém, anterior à regência do princípio do prazer. Existiria no aparelho psíquico uma quantidade de energia psíquica que precisaria ser domada. Essa energia é uma energia livre ou desligada, no sentido de que não tem representações, e, por isso, tem um caráter destrutivo. A pulsão de vida seria justamente a pulsão representada, e, por isso, já sob o domínio do funcionamento prazer-desprazer, enquanto a pulsão de morte não se explica pelo mesmo princípio. Podemos afirmar que a pulsão de morte é aquém ao princípio do prazer porque está bem localizada entre o momento do autoconservativo e o autoerotismo, no qual o sujeito ainda não tem esse mecanismo prazer-desprazer. $\mathrm{O}$ registro de prazer surge somente quando se inicia o autoerotismo e, então, de maneira muito incipiente, algumas representações são feitas e o prazer começa a reger o psiquismo, ainda que em relação a pulsão parcial.

Quando é nomeada a compulsão à repetição, em 1920(/1990), introduz-se a ideia de que a busca pela morte como destino inevitável é a manifestação deste fenômeno. Consequentemente, surge a questão técnica que precisa ser repensada: analisar uma pessoa não consistiria apenas em interpretar o que era inconsciente para torná-lo consciente, como no princípio, tampouco descobrir as resistências que aparecem repetidas na transferência e comunicá-las ao paciente para que este possa superá-las. Com a noção de compulsão à repetição, as resistências deixam de ser apenas provenientes do inconsciente e passa-se a considerar que elas podem surgir também dos extratos mais elevados da mente, como o superego - as mesmas que provocariam o recalcamento. Se transpor as resistências, como se 
acreditava em 1912(/1990), é uma etapa da análise, o que é analisar nesses casos em que a força da pulsão de morte é a expressão do superego?

Se acompanharmos o desenvolvimento das ideias de Freud, em 1923, 1924 e 1926 (/1990) , há breves passagens remetendo à questão da força do destino, relacionada aos poderes supremos de Deus e/ou da Natureza, como a uma dupla parental à qual o sujeito ainda se acha ligado por laços libidinais. No caso sobre o qual nos debruçaremos, percebem-se a culpa que liga o paciente ao incesto e o destino que o remete ao possível parricídio como os vínculos persistentes com a dupla parental. No verbete do dicionário, a palavra destino é definida assim: "A fatalidade a que estariam sujeitas todas as pessoas e todas as coisas do mundo" (Larousse, 1980, p.271). Como se o sujeito não tivesse saída para o seu inexorável destino. Eugênio mostrava angústia diante da crença de que o caminho existente para o seu futuro era único, como herdeiro de uma linhagem definida por ele como problemática e louca. Ele nada poderia fazer na batalha contra essa repetição, já que se via sem recursos. A questão da herança, para Eugênio, supostamente genética, o levaria ao caminho imaginado por ele como idêntico ao percorrido pelo pai e pelo avô, e que nos introduz o tema da origem do superego e a relação desta instância com a pulsão de morte.

"Ele é bem depressivo, cheio de problemas. A família dele é bem problemática. Eu não me dou muito com ele e tenho medo de ter herdado algumas coisas. . . A família do meu pai é toda problemática. Tem uma tia que tem problemas, aquela psicose maníaco-depressiva, tem outra tia que é fora do ar, ela é bem ausente, esquisita, a minha avó também é louca, a família toda do meu pai tem problemas. O meu avô, pai do meu pai, diz que era uma pessoa maravilhosa, diferente do meu pai. Eu gostaria muito de ter convivido mais com ele, mas tive pouco contato com ele. Ele foi desembargador. Quando já estava aposentado, ele e a minha avó se separaram. Diz 
que isso foi bem difícil para ele. Quando a minha mãe fala que eu sou igual ao meu pai eu acho que eu fico com medo mesmo de ficar assim, meu avô se separou, meu pai se separou.” (Eugênio).

Hoje podemos afirmar que este destino, a compulsão à repetição como descarga da energia desligada, era o que temia Eugênio, embora naquele encontro inicial, ocorrido em outubro de 2000, nem a analista, nem o paciente imaginavam o que estava por vir. O início deste jogo de forças pulsional esboçava-se por meio do sentimento de culpa, em parte consciente, e do temor de assemelhar-se ao pai, denunciando os efeitos de uma possível neurose de destino, explicitados na primeira entrevista. O temor de Eugênio não era o de casar e separar-se, embora conscientemente era isso o que aparecia. Compreendemos que a pulsão de vida, depois de desligada da representação que tinha o casamento na vida desses homens, remetia a um destino "demoníaco" que marca a forte presença da pulsão de morte numa neurose de destino.

Freud (1913/1990), citando Goethe (1808), anuncia o que podemos inferir que viria a se aproximar futuramente do conceito de superego e o caminho para sair da repetição: "Aquilo que herdaste de teus pais conquista-o para fazê-lo teu" (p. 160). A teoria psicanalítica tem sido reducionista ao neutralizar a importância da severidade do superego na conduta do sujeito. Revitalizar a dinâmica da instância superegóica possibilita trabalhar os temas trazidos por Eugênio em sua análise, apossar-se de sua herança, a fim de transgredir o mandato mortífero do superego e viabilizar ao sujeito adquirir autonomia e construir um processo criativo. E, consequentemente, criar outro modelo identificatório para si. Este seria o projeto terapêutico possível para levá-lo a se apossar de sua herança e criar para si o destino que ele quisesse. 
Nos estudos Sobre o Narcisismo: uma introdução (Freud, 1914/1990a), encontramos o primeiro esboço conceitual do que, mais tarde, viria a ser o superego na teoria estrutural do aparelho psíquico. Ao dizer que "um poder dessa espécie, que vigia, que descobre e que critica todas as nossas intenções, existe realmente" (p. 113), Freud nos mostra os prelúdios de seus pensamentos sobre a existência de uma instância crítica. Esta passa ser a responsável por zelar pela satisfação narcisista proveniente do ideal do ego. Além desse rascunho sobre o futuro superego, é na teoria do narcisismo que se articula também o primeiro conceito de ideal do ego, com funções próprias, e como uma instância claramente distinta da instância crítica.

O superego é um conceito teórico polêmico, e, embora tenha sua definição oficial somente em 1923(/1990), os temas do sentimento de culpa e das autocensuras ocupam Freud desde muito cedo em sua obra e são recorrentes. Na tentativa de compreender as perturbações dos melancólicos (Freud, 1917/1990), ele obtém a confirmação da existência de uma instância moral que corrobora o que acabava de afirmar no narcisismo. Nas patologias melancólicas, todavia, era mais facilmente observável "que uma parte do ego se coloca contra a outra, julgaa criticamente, e, por assim dizer, toma-a como seu objeto" (Freud, 1917/1990, p.280).

O que nos interessa nesse primeiro item da dissertação e com esses textos, além de demonstrar os primeiros esboços do conceito de superego, existentes já na época da teoria tópica, é questionar se a noção de que esta instância tão moral e cruel como é apresentada na neurose obsessiva, na melancolia e na paranoia, não é cruel justamente pela maneira como acontece a configuração com os personagens do romance familiar em que se encontra. A questão é a seguinte: se o superego é o agente crítico responsável por certas condutas e comportamentos incompreensíveis, possivelmente ligados à compulsão à repetição, seria possível presumir a presença da pulsão de morte no superego, como sua constituinte?

Sabemos que as experiências que se repetem com frequência e intensidade suficiente nos indivíduos, através de gerações, ficam impressas como heranças do id. Freud (1910/1990; 
1917/1990) utilizou o modelo da substituição do investimento no objeto por uma identificação, por meio da introjeção do objeto no ego, para explicar a homossexualidade em Leonardo, e dar conta do estudo da melancolia. Quando Eugênio fala do temor de ser igual ao pai e ao avô, de estar identificado com eles, não estava falando simplesmente de repetição de um sintoma que é uma separação conjugal, mas sim de como evitar uma compulsão à repetição, que se apresenta em sua vida em atos auto e heteroagressivos, exatamente como ocorreu com gerações anteriores a sua. Esta compulsão à repetição na vida do paciente nos faz refletir sobre como a pulsão de morte se instala no superego de um sujeito e se a presença da pulsão de morte no superego é a responsável pela intensidade da severidade dessa instância no paciente em questão.

Expressões de crimes cometidos pelo superego, que se concretizaram na vida real, são vividas pelo paciente como se este tivesse herdado uma tendência a certos padrões de conduta. A intensidade dessas experiências produz efeitos avassaladores nos caminhos de Eugênio, devido à imaturidade de seu ego para integrar e elaborar tantos estímulos violentos, numa época precoce da sua vida. No trabalho sobre os Criminosos em Consequência de um Sentimento de Culpa (Freud, 1916/1990), existe uma tese de que certos crimes são cometidos em função da existência de um sentimento de culpa no sujeito anterior à realização da má ação de matar o pai e manter relações sexuais com a mãe, e que cometer um crime seria uma forma de produzir um alívio por fixar o sentimento de culpa em alguma situação atualizada, que camuflasse, assim, a culpa proveniente do Complexo de Édipo. Consideramos a hipótese de que os crimes da família de Eugênio são da ordem dos imperativos do superego, e que esses homens estão identificados estaticamente no mesmo ponto do conflito edipiano.

Abordar o tema do estranho é primordial nesse cenário, principalmente se estamos falando de um sentimento de culpa existente antes mesmo de um crime ser cometido na realidade cotidiana, e do sentimento de estranheza diante do alívio que possa gerar o ato de 
cometer um crime. O texto $O$ Estranho (Freud, 1919/1990) é o elo que nos permite associar o que está dito nos Criminosos em Consequência do Sentimento de Culpa, no Narcisismo e em Além do Princípio do Prazer. Os fenômenos que trazem a marca da pulsão de morte, tal como a compulsão à repetição, a reação terapêutica negativa e a autopunição nos levam a indagar sobre os efeitos dessa instância superegóica no psiquismo (Freud, 1919/1990). Eugênio tinha a sensação de que se ele nada fizesse por si mesmo acabaria igual ao pai e ao avô. A ideia de destino presente em seus pensamentos referia-se à compulsão à repetição, um temor de que o recalcamento não dominasse tal intensidade. E que parte dessa intensidade escapasse ao recalcamento, ficando, portanto, sem representações e deixando que a pulsão de morte tomasse conta dele. $\mathrm{O}$ estranho mostraria novamente sua face, só que agora na vida de Eugênio.

O Estranho foi publicado um ano antes de Além do Princípio do Prazer (1920/1990), contendo um resumo do que seria desenvolvido nesse segundo texto sobre o fenômeno. A sensação de estranheza de Eugênio provinha exatamente daquilo que encontramos como definição do estranho na obra freudiana: o estranho para o paciente é o que lhe era familiar, velho, assustador, que devia ficar nas profundezas do inconsciente, mas veio à luz, por meio de identificações e vivências que fugiam ao recalcamento e emergiam à superfície do consciente. Agora, o jovem cometia atos que ele não reconhecia como seus, mas eram praticados por ele: as brigas com a namorada e as crises explosivas de raiva, ciúmes e instabilidade que ocorriam nessas brigas, nas quais ele perdia o controle sobre si mesmo, desejando fortemente jogar-se da ponte de um viaduto movimentado da cidade. Pensamentos que lhe causavam angústia e sentimento de desamparo por não entender o que acontecia a ele. As brigas, que ele reconhecia acontecerem sem motivo realmente importante, eram conteúdos que escapavam ao recalcamento, justamente pelo trauma psíquico advindo da intensidade das cenas que ele presenciou; suas atitudes nas brigas com a namorada eram descargas executadas 
por ordem do superego, uma compulsão à repetição que, se ele não dominasse, o destino familiar se cumpriria.

A dinâmica do namoro de Eugênio com a moça mais velha perpetuava uma relação com funcionamento homossexual e incestuosa que existia na relação do menino/adolescente com o pai. A reação do analisando era desconhecida para ele, mas se tratava de um antigo tema de sua vida, que era a depreciação do menino pelo pai, a raiva que sentia desse pai e ao mesmo tempo a falta de um homem que o ensinasse a ser homem. Os estudos de Freud sobre o tema do estranho nos permitem fazer uma relação estreita da compulsão à repetição com o superego quando ele afirma que

a ideia do duplo não desaparece ao passar o narcisismo primário, pode receber novos significados dos estágios posteriores do desenvolvimento do ego. Forma-se ali, lentamente, uma atividade especial, que consegue resistir ao resto do ego, que tem função de observar e de criticar o eu, e de exercer uma censura dentro da mente, e da qual tomamos conhecimento com a nossa consciência (1919/1990, pag. 294).

Ao equivaler o ideal do ego ao superego, definindo-os como sendo a mesma instância formada a partir das identificações parentais - na qual ao renunciar à satisfação pulsional o sujeito interiorizaria a interdição parental -, Freud (1923/1990) define o superego como resultante de um emaranhado de identificações que se estabelecem na relação com a dupla parental. Na impossibilidade de recalcar essas identificações, o trabalho de elaboração e ressignificação do que está sendo incorporado ao psiquismo não ocorre. Sem essa distinção, o ideal do ego e o superego são colocados em um mesmo patamar, ficam como aquela categoria do assustador que remete ao que é conhecido, velho e familiar. O estranho, que surge na vida adulta, é o responsável pelas manifestações mortíferas da compulsão à repetição executadas pela mão do superego. 
O texto Ego e o Id (Freud, 1923/1990) propõe mudanças nas teorias do narcisismo, tópica e das pulsões. Em função dessas modificações, Freud passa a pensar nas categorias de mescla e desmescla, ou "fusão" e "desfusão" das pulsões (pag. 56), assim nomeadas por ele, norteando como as duas classes de pulsões se misturam e se ligam umas às outras e estão presentes em todas as atividades dos seres humanos, embora em proporções diferentes. Para Freud, é natural indagar se não poderia haver vinculações a serem traçadas entre as estruturas que presumiu existirem do id, ego e superego e as duas classes de pulsões. Esse entendimento é o que dá abertura para o nosso questionamento acerca da presença da pulsão de morte na constituição do superego.

No capítulo V do texto de 1923(/1990), o sentimento inconsciente de culpa é tratado por meio da neurose obsessiva e da melancolia. Traçam-se as semelhanças entre esses dois padecimentos, que são uma tensão no ego causada pela ira dirigida contra ele pelo superego dotado de uma severidade exacerbada. A diferença entre as duas patologias é que, no caso da melancolia, o ego assume a culpa mediante uma identificação com o objeto por ele introjetado. A ira é destinada ao ego que agora é representante do objeto originalmente odiado. Porém, fica claro que não é isto o que está em pauta para Freud. Sua intenção é retomar o enigma de como um aumento do sentimento inconsciente de culpa pode transformar pessoas em criminosas. E a hipótese de que tal sentimento não seria derivado de um crime, mas sim o propulsor do crime, uma vez que o ato do homicídio aliviaria o sentimento inconsciente de culpa, como já tratamos na menção ao texto de 1916(/1990) .

O problema principal para Freud (1923/1990), no tocante à compreensão da relação das duas classes de pulsão com o superego, traduz-se da seguinte forma: de que forma o superego se manifesta essencialmente como crítica ao ego e, além disso, desenvolve tão extraordinária rigidez e severidade para com o ego? Partindo do entendimento da melancolia como o estado em que o ego se identifica com o objeto, e enfrenta uma crítica exacerbada por 
parte do superego, o autor segue na sua linha de pensamento sobre sadismo, afirmando que o "componente destrutivo entrincheirou-se no superego e voltou-se contra o ego. O que está influenciando agora o superego é, por assim dizer, uma cultura pura do instinto de morte..." (Freud, 1923/1990, pag.69).

Embora tenhamos a tendência de exaltar o capítulo III do texto Ego e o Id, realmente importante nos estudos da segunda tópica, o capítulo $\mathrm{V}$, menos trabalhado e discutido, tornase, para essa pesquisa, um texto essencial. É nesse estudo que encontramos os três destinos possíveis para a pulsão de morte. São eles: uma parte é tornada inócua por sua fusão com as pulsões de vida, uma parte transformada em agressividade e desviada para o mundo externo, e uma grande parte continua seu trabalho silencioso no interior do aparelho psíquico. Segue pertinente a seguinte questão: como é que na melancolia o superego pode tornar-se uma espécie de reunião para as pulsões de morte?

Certamente que consideramos a existência do destino pulsional de volta contra si mesmo, situação em que a agressividade dirigida a um objeto externo retorna para o próprio ego; no capítulo V do texto do Ego e o Id não é disso que Freud está falando, mas de uma nova hipótese que é introduzida aqui pelo autor e tem sido motivo de alguns debates teóricos entre psicanalistas que se ocupam dos temas do superego e da sublimação. A tese freudiana parte do surgimento do superego a partir de uma identificação com o pai tomado como modelo, e de uma afirmação de que toda identificação dessa ordem tem uma natureza de dessexualização ou sublimação. Aos olhos de Freud, quando uma transformação desse tipo se dá ocorre ao mesmo tempo uma desfusão pulsional - que, nessa data, ele nomeia de sublimação. Após esse primeiro evento, o componente erótico não teria mais o poder de unir a totalidade da agressividade que com ele se achava combinada, e esta é liberada sob a forma de uma inclinação à agressão e à destruição. Ou seja, uma quantidade de pulsão restaria sem 
representação. Para Freud, essa seria a fonte do caráter geral de severidade e crueldade apresentado pelo ideal - o seu ditatorial "farás".

Pode parecer, numa primeira leitura, que esta hipótese refere-se ao mecanismo da sublimação, mencionado por Freud no texto. Porém, no desenvolvimento do estudo sobre as duas tópicas, o autor dá um sentido diferente para dessexualização em cada uma das teorias, a tópica e a estrutural. Se na teoria da primeira tópica o sentido de dessexualização é o desvio do alvo sexual, ou seja, mudar a meta sexual para outra não-sexual, ideia presente no artigo Moral Sexual Civilizada e Doença Nervosa Moderna (1908/1990a), na teoria da segunda tópica, dessexualização passa a significar a transformação da libido sexual do objeto em libido narcísica e, assim, ter outro objeto como alvo da satisfação pulsional e não outra meta, conforme encontramos nos trabalhos freudianos de 1914, 1920, 1923 (/1990).

A mudança na compreensão do que é dessexualização nos permite questionar se a hipótese levantada em 1923(/1990) por Freud, de que a identificação paterna necessária na constituição do superego tem sua origem numa desfusão ou sublimação, está realmente referindo-se à teoria da sublimação. Uma alternativa seria pensar se, nesse trecho do texto, Freud não estaria nos dando exatamente o elemento de que precisamos para sustentar a questão de que esse mecanismo de desfusão necessário na identificação paterna seria o movimento de constituição do superego. Nesse caso, portanto, haveria a presença de pulsão de morte no movimento constituinte dessa instância. A frase seguinte de Freud, de que essa desfusão libera uma agressividade responsável pelo imperativo superegóico do "farás", é um indicador, na nossa leitura, de que esse parágrafo do texto refere-se, sim, à constituição do superego e não ao destino pulsional da sublimação. E, portanto, a crueldade do superego não aparece só na melancolia e na neurose obsessiva, mas também nas psicopatologias em que há presença do superego na formação de sintomas. 
Em Esboço de Psicanálise (Freud, 1940[1938]/1990), há um retorno à ideia de que a "herança" deverá ser encarada sob o prisma da "pré-história pessoal" (p.171). Segundo Freud (1940[1938]/1990), o id e o superego teriam em comum o fato de representarem as influências do passado. Há, nesse momento da obra, uma importante distinção traçada de que o id representaria a influência da hereditariedade pulsional e o superego basicamente a influência daquilo que é herdado do outro. Então, do lado do id, a herança é da ordem do pulsional, ao passo que, do lado do superego, provém do outro externo. O superego estaria relacionado ao que é transmitido de um passado cultural para o presente, herdeiro do Édipo. No entanto, como encontra raízes profundas no id, fica com o paradoxo de que também é derivado da "pré-história pessoal".

Chegamos a um entrave na teoria do superego. Ao findar o texto de 1940[1938](/1990) , Freud afirma que a constituição do superego seria baseada numa transmissão e, principalmente, num processo de retomada desse vivido inconsciente vindo do exterior, do outro. Freud, ao evocar os versos de Goethe nos textos Totem e Tabu (1913/1990) e Esboço de Psicanálise (1940[1938]/1990), o faz com a conotação de apropriar-se da herança: exigências de um trabalho psíquico singular e necessário de retomada interna frente à herança parental não recalcada. Porém, compreender o que é, afinal, o superego em Freud, exige que formulemos novas indagações: como entender o superego no papel de herdeiro tanto da transmissão do que é culturalmente passado pelo outro como da "pré-história pessoal"? É o ideal do ego apenas uma face do superego? Não seriam o ideal do ego e o superego instâncias diferentes, cada uma com origem, funções e dinâmicas distintas?

A questão da herança pode ser entendida a partir do que Freud (1917/1990), denomina de acervo filogenético, do qual, por meio do pulsional que está no id, herdaríamos as fantasias de retorno ao seio materno, a fantasia de castração e as fantasias de sedução infantil. Essas seriam as protofantasias da espécie, herdadas pelo id, e que serão pano de fundo para a 
criação das fantasias geradas no período edípico. Estas últimas seriam o resultado da herança transmitida culturalmente e são singulares na medida em que dependem da história edípica de cada um. Como psicanalistas, podemos nos ocupar com o que seria ontogenético, ou seja, da ordem do que é recalcado, e não com o que é da ordem da espécie, do código genético. Eugênio, equivocadamente, pensava que o que se encontrava em seu psiquismo era geneticamente herdado. É preciso esclarecer, aqui, que o psiquismo se constitui a partir do que é vivenciado com o outro.

Ainda na entrevista inicial de Eugênio, encontramos um recorte clínico que mostra a força da herança. Este recorte surge para nos auxiliar no trajeto de elucidar a hipótese da herança vinda de fora para dentro, por meio do recalcado do outro que é transmitido ao sujeito e que se define como o estranho. O fato clínico marca a posição de passividade do paciente e a sua incapacidade de fazer o trabalho de discriminação do que lhe estava sendo transmitido, entre o que é seu e o que foi introjetado mediante uma identificação paterna primária.

“E aquele mesmo mês minha avó pediu para se separar, ela é louca, muito louca. Sei lá porque ela quis se separar e diz que meu avô não aguentou isso e se matou. Meu pai estava em Miami e o meu avô tinha ido dar uma volta comigo e com o meu irmão. Eu me lembro deste dia. Na volta ele nos largou em casa e chamou a minha mãe, deu um dinheiro para ela nem sei quanto seria hoje, mas um bom dinheiro, para ela colocar um pouco na minha conta e um pouco na conta do meu irmão. Deu tchau para nós, foi para casa e se matou. Ele se deu dois tiros.” (Eugênio).

Mesmo iniciando uma análise com a frequência que correspondia a demanda de seu padecimento, o paciente revivia as tragédias em seu ego com tanta intensidade e violência que conseguia contar as cenas traumáticas apenas gradativamente. Desse modo, Eugênio evitava 
um transbordamento de angústia no ego capaz de levá-lo a alguma compulsão com o intuito de buscar a morte, como mais uma batalha vencida pelo sadismo do superego. Mas permanecia estarrecido diante da violência presenciada que ainda estava colada a seu ego, sem conseguir uma plasticidade maior da libido. Ele não entendia por que a cada briga que acontecia com sua namorada, nas quais ela ameaçava o deixar, ele ficava tão angustiado a ponto de pensar que algo de horrível lhe aconteceria.

Um mês depois de contar o episódio do suicídio do avô, ele volta ao assunto da herança. Desta vez já na segunda geração da família, evidenciando a intensidade e frequência dos acontecimentos que estavam marcados, como a ferro quente, em suas memórias.

“Nós vamos continuar falando do que nós estávamos falando na terça-feira, do meu pai. Ele tem problemas sérios, ele bebe todos os dias. Meu avô bebia cerveja e meu pai bebe também... É muito difícil para eu contar isso para alguém, nem os familiares falam nisso, é a pior coisa para eu te contar. Um dia ele alugou uma cabana para recreação e foi passar uns quatro, cinco dias. Ele foi para lá e bebeu muito, de madrugada resolveu voltar, sei lá fazer o quê. Ele tinha comprado um carro velho e daí aconteceu uma tragédia. É a pior coisa para eu te contar. Ele atropelou um velhinho e ele morreu. Daí ele me ligou e me disse o que tinha acontecido e eu disse “o que tu queres que eu faça?”. Ele respondeu: “nada”. Como é que eu não vou fazer nada? Ele estava bêbado, sem documentos, foi preso na hora porque ele dizia que era desembargador e não acreditavam nele. Também, sem documentos, mal vestido, assim com roupas normais mas uma camisa meio velha e aberta até o meio do peito e com aquele carro velho! Aí ele pediu para chamar a Ana - irmã dele que é advogada. Foi a pior cena da minha vida! Chegar lá e ver meu pai daquele jeito, estava bêbado com aspecto horrivel! Olhos vermelhos, a pele vermelha, mal vestido, na delegacia. Depois 
que eu levei documentos dele lá eu o acompanhei até o IML para resolver os negócios do cara que tinha morrido. Eu que tive que decidir tudo, imagina como é que ficou a minha cabeça. Foi horrível, a pior noite da minha vida. A minha cabeça estava muito confusa. Pô! Eu era um guri, não tinha nem entrado na faculdade ainda.” (Eugênio).

O avô suicida-se e o pai comete um homicídio considerado culposo por um por um tribunal especial, o que juridicamente significa que o sujeito assumiu o risco de matar alguém, embora não tivesse a intenção de matar - conforme nos esclarece Eugênio. O pai foi julgado, condenado e teve uma pena a cumprir, que consistiu em pagar cestas básicas para uma entidade carente por um período de longos anos e prestar serviços à comunidade. Eugênio, no decorrer da sessão, diz que o acidente do pai ocorreu para que a cena parasse por ali, senão uma tragédia maior ainda aconteceria. O pai estava armado e dirigia-se à casa da segunda exesposa, deixando implícita a suspeita de que pudesse vir a cometer um crime passional, ou seja, matá-la.

Lembremos que certa vez Eugênio referiu-se ao avô como sendo um homem maravilhoso e o pai um homem horrível. Alguns meses depois, aproximadamente oito meses após o início da sua análise, o paciente admitiu, muito brevemente, que, nos momentos de desespero, pensava ser sua única saída jogar-se de uma ponte específica de um viaduto, localizada sobre uma avenida movimentada na cidade, muito próxima de onde morava o avô e de onde ele residia com a mãe. Esse pensamento marca a ideia de um crime do superego, contra si mesmo, no qual ele estaria sob efeito da compulsão à repetição de um estranho familiar, que o impedia de criar novos destinos para si. Estar identificado com o avô "maravilhoso" nos indica por onde anda seu ideal de ego - suicidar-se. Achando-se covarde para provocar um suicídio, via na religião a alternativa para livrar-se de tal destino, embora quase não falasse sobre isso, também. $\mathrm{O}$ assunto do suposto suicídio sumiu de cena e só volta 
a ser falado no final do tratamento. $O$ tema de se tornar padre entra como um contrainvestimento, na tentativa de ligar a pulsão de morte que trabalhava solta, no seu psiquismo.

A seus olhos, ser padre era seguir um caminho diferente do traçado pelo avô e pelo pai e ainda com o ganho de que seria uma posição mais digna e elevada do que a de seus antecessores. Na sua fantasia, assim iria melhorar a sua espécie, com a ingênua ilusão de que seguindo o caminho religioso estaria livre das compulsões à repetição, portanto, da herança familiar. Talvez Eugênio até conseguisse uma boa formação de compromisso, e aparentemente resolvesse seus conflitos sendo religioso, mas os desejos carnais existiam com a mesma intensidade do desejo de ser padre, tornando-se esse mais um de seus dilemas. Quando a análise já havia lhe assegurado a possibilidade de um novo destino, depois de um processo de quase um ano até confiar na analista e na possibilidade de que juntos poderiam construir novos recursos para ele, é que esses assuntos espinhosos, da religião e do sexo, puderam fazer suas aparições.

Chasseguet-Smirgel (1992) aborda a delicada relação do ideal do ego e da perversão. Quando a mãe alimenta as fantasias do menino, de que ele é suficiente para ela, evita que o filho se depare com a insuficiência que o faria projetar-se no pai como objeto de identificação, perceber sua condição desfavorável para satisfazer a mãe e encontrar-se com o fracasso edipiano. Se isto acontece, favorece-se a constituição da homossexualidade ou da perversão. Aprisionado no ponto do narcisismo infantil, em ele era o par perfeito para a mãe e que estava autorizado a matar o pai, o menino buscava desesperadamente um ideal diferente para agarrar-se e se proteger desses dois crimes, o incesto e o parricídio. A homossexualidade poderia ser uma saída, pois, não transando com a mãe, não seria preciso cometer um assassinato. Porém, não era nesse sentido que sua pulsão sexual estava direcionada, um objeto homossexual, restando, portanto, a religião. Quando Eugênio fala do horror que sente ao ter 
um avô suicida e um pai homicida como modelos de ideal, pensa que estaria elevando a sua raça a algum valor mais digno tornando-se padre, e construindo o que ele acreditava ser outro ideal de ego para si.

O perigo desse destino é que ser religioso é algo tão idealizado quanto ser um desembargador. São figuras que, de maneiras distintas, representam o poder, pela lei de Deus ou pela lei dos homens, mas que de algum modo vivem cercados de rituais. O desembargador segue os rituais de um tribunal, o padre tem todo um cerimonial da igreja, vivendo sob a influência de idealizações que podem funcionar como imperativos superegóicos. A história da religião na vida de Eugênio era bem mais viva e presente do que ele por muito tempo demonstrou e a análise nos mostrava que a saída religiosa não estava sendo suficiente para manter recalcadas as intensidades das catexias amorosas dirigidas à mãe e homicidas dirigidas ao pai.

A saída encontrada pelo paciente - a de ser padre - passava novamente por uma identificação com o avô e o pai, ou seja, a de ser alguém poderoso diante da lei, ainda que de Deus. O raciocínio de que quanto mais forte a presença do desejo incestuoso maior é a necessidade da presença da lei denuncia a hipercatexia dos pensamentos vigentes nessa família, em que todos pretendiam uma forma de lei à margem da tramitação psíquica. A lei dos imperativos superegóicos era o fio que os conectava. Todos os homens seguiam a graduação de direito e um concurso que lhes desse poder de legislar sobre as leis. O tema da identificação se colocou no caminho de Freud em relação à constituição do superego. No caso de Eugênio, poder-se-ia fazer a seguinte análise: ao se identificar com o pai, ocorre uma desmescla pulsional, capaz de gerar um quantum de pulsão de morte no superego que ficaria disponível para possível configuração de uma perversão. Desta forma, ficaria aberta a porta para os atos perversos desmentidos pela batina, bem como, pelo cargo de desembargador. 
Freud (1914/1990) fala da diferença entre a idealização e a sublimação, demonstrando que a idealização refere-se ao objeto, enquanto a sublimação é um processo que diz respeito à libido objetal, que consiste em dirigir a pulsão para outra finalidade que não a satisfação sexual. O que leva às vezes a ocorrer uma confusão entre a formação do ideal do ego e a sublimação? A religião era vista por Eugênio como uma saída, a seus olhos, mais elevada, que o permitiria fazer uma deflexão da sua sexualidade. O que ele não percebia é que essa ilusão o resguardaria de encontrar-se com sua insuficiência edípica, como diz Chasseguet-Smirgel (1992), mascarando o fato de que a religião, no seu caso, estaria a serviço de cumprir uma exigência de ideal. E, vejamos bem, um ideal que ele nos comunica como sendo o de matar ou morrer. A questão a ser trabalhada aqui era indagar o analisando sobre o que ele queria com a religião, qual seria o propósito desta em sua vida - o que pareceu surtir efeito.

Certamente, a essa altura, não poderíamos mais nos prender unicamente às histórias dos homens de sua vida. Eugênio anuncia, por meio da relação com a namorada, do sentimento de culpa, das fantasias de suicidar-se ou ser religioso, a grande complexidade da sua problemática identificatória e a forte presença das mulheres em sua história. Correríamos o risco, como analistas, de nos cegarmos pelo jargão da relação ambivalente do pai com o filho na neurose obsessiva e desconsiderar a trama identificatória com a mãe, assim como a singularidade e a riqueza de como esse romance familiar se constituiu.

Sabemos que a idealização das pulsões parciais confere ao perverso uma completude narcísica, pois ela atinge a idealização de seu próprio ego, mantendo a ilusão de seus atributos infantis - o que é constantemente confirmado pela adoração do fetiche. Assim, o perverso se aproxima do tempo em que ele era seu próprio ideal, mantendo-se na posição de adorável perfeição. Embora Eugênio não seja um caso clássico de perversão, restaria a ele ser seu próprio ideal, já que o pai e avô das cenas relatadas aqui eram figuras nas quais não poderia se espelhar para formar um ideal, eram figuras desprovidas de pulsões de vida. Chasseguet- 
Smirgel (1992) indica que o caminho da obtenção da cura de perversos parece depender da mobilidade do ideal do ego, quer dizer, de um reinvestimento narcísico da imagem paterna. Mas, nesse caso que estamos discutindo existiria uma saída? Qual seria o destino de Eugênio se seguisse o caminho por ele idealizado como sua salvação? A ilusão de proteção parental de Deus o deixaria isento dos tormentos com sua sexualidade? Se não seguisse o caminho de curvar-se a Deus seria um suicida como o avô? Ou um homicida como o pai? Como Eugênio iria construir recursos para se reorganizar com suas identificações e então se utilizar de seu próprio ideal do ego como propulsor criativo de novos destinos pulsionais em sua vida?

\subsection{Identificações Cruzadas}

“É que o meu pai é complicado. Por um lado eu acho que ele é o exemplo que eu tenho de ideal, de ser como ele, ele é um modelo para mim. Por outro lado ele é tudo o que eu não quero ser. É muito complicado.” (Eugênio).

A preocupação evidente de Freud (1923/1990) ao explicar metapsicologicamente a instância moral, que nesta segunda teoria do aparelho psíquico é nomeada de superego, era poder afirmá-la como uma instância derivada de uma transformação das primitivas catexias objetais do bebê em identificações que tomariam o lugar do Complexo de Édipo. Até aquele momento, o conceito de superego atraía seu interesse principalmente pela relação estabelecida com os sintomas da neurose obsessiva, da paranoia e da melancolia. Porém, o ideal do ego, que é a instância que em 1914(/1990) foi considerada como resultante da identificação narcísica, é equiparada, a partir desse texto de 1923(/1990), com o superego, aparecendo em alguns textos como sua equivalente e em outros como diferenciada deste. Trabalhando a origem de cada uma dessas instâncias psíquicas, pretendemos desintrincá-las, devolvendo a 
cada uma o seu estatuto próprio. Para tanto, seguiremos o caminho das ideias de Freud, a fim de encontrarmos argumentos teóricos que sustentem posteriormente o debate metapsicológico que pretendemos alcançar para responder à indagação que ecoa ao longo dos estudos dessa dissertação: afinal, o que é o superego?

Acabamos de afirmar que, em 1914(/1990), no texto Narcisismo, Freud institui uma instância chamada ideal do ego, que é resultante de uma identificação narcísica e é constituinte do sujeito. Porém, tentaremos refazer esse percurso de como se constitui esse ideal do ego um pouco mais detalhadamente. Encontramos nesse texto em que Freud desenvolve a teoria do narcisismo uma explicação de que há um momento inicial no qual a criança, investida libidinalmente pela mãe, é dotada de toda a perfeição de valor. Esse é o momento em que o ego real da criança sente-se a "sua majestade o bebê" e desloca esse narcisismo infantil para a ideia de que ele próprio é o seu ideal. A isso Freud nomeia de ego ideal, designação que raramente aparecerá novamente na obra do autor. Porém, esse breve momento de ocupar um lugar de ego ideal no qual o sujeito vive uma satisfação libidinal intensa não é de pronto abandonado pelo bebê. Freud nos avisa que quando a libido está envolvida, o homem se mostra incapaz de abrir mão de uma satisfação que já desfrutou em outros momentos. Sendo assim, quando surgem interpelações de terceiros ou entra em ação o próprio julgamento crítico do bebê, essa posição de perfeição não é mais sustentável e o sujeito tenta recuperar esse lugar. Isto é feito por meio da projeção, diante de si, como seu ideal, do substituto do narcisismo que ele está perdendo, reafirmando o momento em que ele era seu próprio ideal. O ideal do ego é o substituto do ego ideal, ou seja, do narcisismo perdido de um tempo da infância no qual o sujeito era seu próprio ideal.

A formação do ideal é muitas vezes confundida com a sublimação da pulsão (Freud, 1914/1990), como já marcamos no ponto acima estudado. Porém, o ideal do ego implica um movimento de idealização do ego, no qual a libido fica superinvestida, em um lugar 
equivocado que são os ideais narcisistas projetados em forma de ideal do ego. Essa projeção narcisista aumenta as exigências do ego e constitui um fator importantíssimo a favor do recalcamento, diferentemente do mecanismo da sublimação que diz respeito ao movimento da libido objetal. É nesse sentido que Freud define que não seria surpresa se encontrássemos um agente psíquico especial que fosse capaz de assegurar a tarefa de satisfação narcisista proveniente do ideal do ego, e que, com essa finalidade, observasse constantemente o ego real, medindo-o pelo ideal existente. Essa é a primeira definição que encontramos, na obra psicanalítica, de que existe uma instância psíquica especial, claramente diferente da instância que ele acabara de nomear como ideal do ego; essa ideia é sustentada por meio da explicação dos delírios dos paranoicos. Sobre a formação do ideal do ego é acrescentado, ainda, que o sujeito foi induzido a formar um ideal do ego pela influência crítica de seus pais.

No texto do Ego e o Id (Freud, 1923/1990) surge uma definição formal e oficial sobre a instância crítica que insiste em aparecer nas investigações de Freud. O termo superego é, enfim, nomeado, sendo definido como uma gradação no ego, uma diferenciação dentro deste que pode ser chamada de "ideal do ego" ou "superego". Esta instância é menos ligada à consciência e passa a ser oficialmente o herdeiro do Complexo de Édipo, além de ter funções específicas de consciência moral, auto-observação, de julgar e punir. Nesse texto, encontramos ainda a descrição do superego como sendo derivado de dois fatores, um pulsional, que teria relação com a parte herdada do id, e outro histórico, remetendo-nos ao prolongado tempo de desamparo do homem e ao recalcamento do Complexo de Édipo. No tocante à relação com a parte herdada do id, abordamos acima o lugar das protofantasias. Ocupar-nos-emos, então, do herdado histórico que nos remete às identificações resultantes do Complexo de Édipo.

Laplanche e Pontalis (1992) definem o ideal do ego como uma instância da personalidade resultante da convergência do narcisismo e das identificações com o pai e com 
os ideais, e que, como instância diferenciada, constitui um modelo a que o sujeito procura se conformar. Para esses autores, a dificuldade de encontrar um sentido único na obra de Freud para ideal do ego reside justamente no fato de que essa instância está estreitamente ligada à elaboração progressiva da noção de superego. A conceituação de superego, no entanto, segue a encontrada em Freud, ou seja, a de uma instância da personalidade, da segunda teoria do aparelho psíquico, que desempenha um papel semelhante ao de um juiz ou de um censor em relação ao ego. Nessa definição, as funções do superego são de consciência moral e formação de ideais e constituem-se a partir da interiorização das exigências e das interdições parentais ou seja, referem-se ao que resulta do recalcamento do Complexo de Édipo.

Inevitavelmente, teremos que enfrentar, agora, a trama de identificações, que podemos rastrear em Freud principalmente a partir de Totem e Tabu (Freud, 1913/1990). É nesse livro que encontramos o mito de Darwin sobre o assassinato do pai cometido pelos filhos que aponta para indícios de que há uma identificação primária que está na base da lei. Na horda primeva, assistimos à cena que institui, no momento em que os filhos canibalisticamente incorporaram o pai, a identificação com a figura que representava a autoridade: estamos falando de identificação primária, o tema é da ordem do ser, ser como o pai. No mito de Darwin, o ritual canibalístico de incorporação oral do pai é um evento que não acontece sem um preço caro, pago com a moeda do sentimento de culpa. Pois o remorso de matar o pai e devorá-lo para ser como ele fez com que os filhos criassem a lei que proibia o incesto e o parricídio. Ser como o pai abre margem para a concretização do incesto, que é ter a mãe; a lei passa a existir para regular o desejo dos homens e é internalizada por um ato de incorporação oral.

A descrição dos quadros melancólicos, em 1917(/1990), dá seguimento ao estudo das identificações e apresenta, entre tantas características, uma específica, ligada à crítica da instância moral, que é o sentimento de depreciação de si. Este pode ser tão intenso que chega, 
em certos casos, a se apresentar quase que como um quadro de delírio de inferioridade (moral), como encontramos no texto de Freud (1917/1990). Outra questão referente aos quadros da melancolia, ligada a essa instância moral, diz respeito ao sofrimento relativo à perda que escapa à consciência, fazendo com que o sujeito não saiba reconhecer o que perdeu, nem quem perdeu. Freud (1917/1990) nomeia novamente, na primeira tópica, a existência de uma instância responsável por esses sintomas de consciência moral. Lembremos que em 1914(/1990) já havia comentado a existência de uma instância especial capaz de vigiar as ações do ideal do ego. Esta se contrapõe a parte do ego, promovendo uma insatisfação com o ego, de ordem moral, que consiste na característica mais marcante da melancolia. Porém, a chave dessa incógnita de como surge no psiquismo algo tão cruel estaria no processo de identificação narcísica.

Freud (1917/1990), ocupado em definir a identificação narcísica, se utiliza desses quadros de melancolia para demonstrar como se dá o seu processo. Inicialmente, a libido é direcionada a uma pessoa em particular. Esse movimento, no entanto, leva a uma decepção, causada pelo próprio objeto amado. A relação objetal fica, assim, destroçada, e o resultado que podemos esperar nem sempre é o normal de uma identificação, que seria o deslocamento da libido deste objeto que provocou a decepção para um novo objeto. Quando não há esse deslocamento e a libido fica represada no ego, ocorre uma patologia. A sombra do objeto recaindo sobre o ego é o que presenciamos nesse caso. A libido que deveria ser deslocada para outro objeto é reinvestida no ego, sendo que agora há uma introjeção no ego desse objeto perdido que não pode ser abandonado. A explicação de que uma perda objetal se transforma numa perda do ego, e que o conflito entre o ego e a pessoa amada passa a ser um conflito entre a atividade crítica do ego e o ego enquanto alterado pela identificação, é sustentada a partir desse modelo de identificação que traz embutida uma característica importante: a identificação feita sob uma base narcísica de escolha de objeto. 
Encontramos a explicação da identificação primária ou narcísica nas psicopatologias melancólicas numa contradição no texto de 1917(/1990), apontada por Freud. Para uma identificação deste tipo ocorrer, existem duas coisas que seriam pré-condições: uma forte fixação no objeto amado, por um lado, e, por outro, contrariando as bases narcísicas de eleição de objeto, a catexia objetal deve ter tido pouco poder de resistência nesse investimento inicial. Freud (1917/1990) atribui a Otto Rank a explicação que tenta dar conta dessa contradição. Freud (1917/1990) observou que esse paradoxo existe justamente porque a escolha objetal foi feita numa base narcísica, de modo que a catexia objetal, ao se defrontar com obstáculos, retrocede ao narcisismo. Assim, a identificação secundária ou narcísica com o objeto se torna um substituto da catexia amorosa. Apesar do conflito com a pessoa amada, a relação amorosa fica preservada, mostrando que, numa identificação dessa ordem, o investimento amoroso pelo objeto não pode ser renunciado, embora o próprio objeto o seja.

Em Psicologia de Grupo e Análise do Ego (Freud, 1921/1990), há um capítulo dedicado exclusivamente ao tema das identificações, como uma forma encontrada pelo próprio Freud de organizar as ideias a respeito das formas de identificação existentes e diferenciá-las. Ele já havia trabalhado a noção de identificação histérica no início de suas investigações psicanalíticas, por meio do caso Dora (1905/1990a) e do sonho do salmão defumado (1900/1990a), sendo que, naquela época, a identificação era tratada apenas como um mecanismo de formação dos sintomas ou dos sonhos. Nessa retomada, ele já está com uma visão mais abrangente do tema da identificação, partindo da ideia de que a identificação é, na psicanálise, a mais remota expressão de um laço emocional com outra pessoa. Ou seja, a identificação passa a ser um mecanismo constituinte do sujeito e não somente formadora de sintomas.

Encontramos, então, três tipos de identificação, em 1921(/1990) : a identificação primária, que constitui a forma mais originária de laço emocional com um objeto e, segundo 
Freud, desempenha um papel importante na pré-história do sujeito; a identificação narcísica, que, de maneira regressiva, se torna sucedânea de uma vinculação de objeto libidinal, por meio da introjeção do objeto no ego, como observado em melancolias e na homossexualidade; e, por fim, a retomada da identificação histérica, que continua sendo responsável pela formação do sintoma neurótico - no sentido de que pode surgir com qualquer nova percepção de uma qualidade ou desejo inconsciente, partilhado com qualquer pessoa que não seja o objeto de investimento amoroso da pulsão.

A ideia de identificação primária como constituinte do sujeito, tal como vimos demonstrada por meio do mito de Darwin em Totem e Tabu, de identificar-se com o pai tomando este como ideal, desejando ser como este e inclusive tomar o lugar deste, deixa uma incógnita. Ele fala de uma identificação imediata e direta com o pai, mas, se é chamada de primária por ser anterior ao Édipo e nada ter a ver com atitude passiva ou ativa em relação a um objeto masculino, é necessário considerar que isto ocorre porque ainda não existem ego e diferenciação anatômica (Mayer, 1989). Porém, Freud percebe essa encruzilhada e propõe-se a encontrar uma solução em 1923, quando, numa nota de rodapé do texto Ego e o Id (1923/1990), expõe uma solução ao dizer que a identificação primária não é necessariamente com o pai, mas com os genitores. O que nos permite absorver a ideia de que essa identificação ajuda a preparar o caminho para o Complexo de Édipo, na medida em que se torna precursora de uma vinculação de objeto com os genitores, ou seja, ela é constituinte do sujeito.

A segunda identificação, trabalhada em 1921(/1990), é a resultante do Complexo de Édipo na qual o pai é o que gostaríamos de ter - no caso de um Complexo de Édipo feminino. Essa identificação é chamada de narcísica, ou de secundária por autores pós-freudianos, porque se refere a um segundo movimento de identificação, agora já em busca de eleger um objeto sexual, ou seja, há uma escolha de objeto amoroso. Em função de haver uma interdição por uma das figuras parentais, que no caso não foi o eleito como objeto de amor, podemos 
afirmar que a escolha de objeto retroage para a introjeção do objeto no ego, como forma de não abandoná-lo como objeto de amor: o ego, então, esforça-se por moldar-se segundo o aspecto daquele que foi tomado como objeto de amor.

Existiria ainda um terceiro tipo de identificação que nomeamos de identificação histérica porque é essa identificação que está envolvida na formação do sintoma, sendo particularmente frequente. Nela, a pessoa deixa de fora qualquer vinculação de objeto com a pessoa à qual busca se moldar. Somos alertados a ficar atentos para notar que, neste tipo de identificação, o ego às vezes copia a pessoa que não é amada e, em outras, a que é. Em ambos os casos, Freud afirma que a identificação é parcial e extremamente limitada, tomando emprestado apenas um traço isolado da pessoa que é objeto dela. O mecanismo envolvido nessa identificação é a possibilidade ou desejo de colocar-se na mesma situação da pessoa com quem o ego está se identificando, ou melhor, identificar-se com o desejo de alguém. Esse modelo de identificação tem a ver com o retorno do que não foi exitosamente recalcado, deixando vir à tona um desejo do id, disfarçado em um traço que acaba por formar um sintoma psíquico.

O caso de Eugênio ilustra o percurso da libido no processo de escolhas objetais que resultam em identificações narcísicas, o modelo do luto e melancolia, e, também, uma identificação histérica, que abordaremos no ponto seguinte. Vamos refazer, na medida em que avançamos na teoria das identificações, o trajeto da trama identificatória do paciente, acompanhando as falas deste na análise. Percebe-se que desde o início da análise há uma questão confusa para Eugênio sobre quem ele é e quem ele quer ser. O pai de Eugênio é um profissional admirado pelo rapaz e um modelo de como o paciente quer ser em sua própria vida profissional, tanto que ele cursava a mesma faculdade que o pai havia cursado. Acontece que esse pai é uma decepção para Eugênio no exercício da função paterna e como modelo do que é ser homem. Aparece então o temor de ele de ser como o pai, um desejo de não ser como 
este homem. Até agora o enigma do paciente é: como fazer para ser homem sem ser homem como o pai?

Acontece na história de Eugênio uma identificação narcísica com o pai, da ordem de ser como o pai. A questão é que, avançando no seu desenvolvimento psicossexual, rumo ao Complexo de Édipo, Eugênio elege a mãe como objeto de amor e, para identificar-se com o pai, na tentativa de ser como o pai para ter uma mulher como a mãe, ocorre o inesperado. A afirmação freudiana (1917/1990) de que um destino diferente pode acontecer à libido diante de uma decepção com objeto amoroso é o que podemos observar com Eugênio: o pai, que foi escolhido com objeto de amor num primeiro momento, admirado, idealizado, inscrito no desejo de Eugênio de ser como ele, é motivo de intensa decepção por parte desse filho. Eugênio percebe a existência de um pai bêbado e agressivo com a mãe, um pai que não lhe dava atenção, que repetidas vezes o depreciava e o menosprezava, que atropelou e matou um velhinho. Tudo isso o levou a dar outro rumo à sua libido.

Como vimos anteriormente, para que a identificação com um objeto amoroso seja bem-sucedida, esse objeto precisa ser abandonado e a libido reinvestida em novo objeto, o que não acontece nesse caso. A libido livre resultante da decepção não foi deslocada para outro objeto de amor, mas sofreu uma retirada para o próprio ego, estabelecendo ali uma identificação com o objeto perdido. O pai de Eugênio, agora, habitava seu próprio ego. A impossibilidade de Eugênio de abandonar esse pai como objeto de amor e modelo de ideal advinha do fato de não ser reconhecido por esse pai como um filho provido de valores. Essa situação abalava profundamente o sentimento de autoestima de Eugênio, não permitindo que ele projetasse diante de si o próprio narcisismo como um ideal de ego. A sombra do objeto/pai recaindo sobre o ego de Eugênio é o que presenciamos com as frases do paciente, quando diz “se eu não mudar vou ficar igual a ele mesmo". 
Ainda que o paciente dissesse que não queria ser como pai, tinha uma percepção de que já era, em parte, como o pai, e justamente por isso buscava uma análise, pelo estranho que havia nele. Algo escapava ao recalcamento, que ele percebia em sua consciência como uma força que o dominava e exercia influência em suas atitudes, mostrando a face do fantasma que o habitava. Por exemplo, nas constantes brigas infundadas com a namorada, nas crises de raiva, no desejo de ser padre e na impossibilidade de manter relações sexuais com a namorada. A explicação freudiana de que há na melancolia um deslocamento do conflito entre o ego e a pessoa amada para um conflito entre a atividade crítica do ego e o ego enquanto alterado pela identificação é exemplificada pelas constantes autorrecriminações que Eugênio fazia à sua pessoa, inclusive pensando ser tão horrível que a única saída seria se matar. Essa dinâmica não era algo compreensível para ele. Depois de certo tempo de análise, o paciente começa a perceber que suas dificuldades atuais estavam diretamente ligadas ao intenso romance familiar no qual se achava aprisionado:

“Como é que eu ia conseguir transar, se até seis meses antes de começar a namorar com a Eduarda eu ainda dormia na cama da minha mãe com ela? Naquela época que eu dormia na cama da minha mãe eu fiquei muito confuso. Não dava, né, doutora! Eu ia sair da cama da minha mãe e ir direto para a cama com a Eduarda? É demais para mim, doutora. E tem mais, se não bastasse isso, ainda tinha outra questão que eu até agora não te falei, eu tinha minhas dúvidas sobre se eu queria ou não ser padre. Agora me diz, dá para alguém conseguir transar com tudo isso na cabeça?” (Eugênio).

$\mathrm{Na}$ época em que a cena transcorreu, Eugênio tentou buscar auxílio com o pai para resolver o problema de não conseguir manter uma ereção com a namorada. Conta que ficou 
angustiado pensando se gostava de homens, mas que não era essa a questão. Ele gostava de mulheres e tinha excitação pela namorada. A solução que o pai ofereceu ao filho foi que procurasse uma prostituta e fizesse sua iniciação assim, com uma mulher de quem não gostasse, que não conhecesse e com quem não tivesse envolvimento algum. O paciente ficou profundamente magoado e decepcionado, reeditando decepções anteriores da infância, época em que, de fato, não tinha recursos para discriminar que o pai era uma pessoa muito atrapalhada com seu narcisismo e descontava a imensa falha que tinha no seu valor próprio depreciando o filho.

Eugênio ficava aprisionado numa identificação melancólica, com uma falha narcísica do pai, de ser desprovido de valor. Na complicada teia edípica a que se achava preso, mais evidenciada na relação ambivalente com o pai - tentando nos ludibriar com a famosa relação do obsessivo com seu pai-, encontramos os esboços de uma possível relação de intenso desejo pela mãe, evidenciados na confissão de culpa inicial do paciente. Seguindo essa pista, encontramos um Édipo espinhoso, e começa a tomar corpo a possibilidade de um incesto real, a partir da cena, relatada por ele, de que dormia com a mãe até seis meses antes de começar a namorar. Novamente as identificações se complicam, pois cometer o incesto o levaria ao suicídio. A saída era, então, identificar-se com a mãe para encontrar outro homem com o qual Eugênio reproduzisse a relação de intenso amor que havia vivido por longos anos com a mãe.

As identificações homossexuais, resultantes de um modelo de identificação narcísico, que já trabalhamos anteriormente, descambam para o lado de um Complexo de Édipo invertido, que será anunciado numa sequência de atos falhos em relação a um segundo casamento do pai, como ilustraremos em breve. A complexidade desse caso está justamente no excesso de catexias geradas pelas cenas reais. O que escutamos do paciente não são derivados inconscientes que aparecem como fantasias, são cenas vividas na realidade factual do rapaz, na qual o incesto e o parricídio são possibilidades concretas presentes em cenas que 
ele viveu na cama com a mãe por quase dez anos de sua vida e em cenas de violência cometidas pelo pai presenciadas dentro de casa na infância e, na rua, durante a adolescência. Diante da relação com a mãe, que fugia dos parâmetros afetivos de uma relação maternal, Eugênio viu-se obrigado a introjetar narcisicamente também a mãe dentro de seu ego, como forma de novamente não abandonar o investimento amoroso nesta mulher e numa tentativa desesperada de não ceder às suas investidas, moldando conforme a mãe aspectos do seu ego.

Eugênio percebia-se empobrecido, sem recursos psíquicos para lidar com tudo isso. O tormento de viver com duas identificações narcísicas no seu próprio ego, uma com o pai e outra com a mãe, o deixavam atordoado, pois estava cada vez mais evidente a dimensão enlouquecedora de sua cadeia identificatória. Ao mesmo tempo em que amava a mãe e a desejava como objeto amoroso, odiando o pai, também amava o pai como objeto amoroso e ficava identificado com a mãe. O sentimento de culpa derivado dessa trama edípica era avassalador e deixava a analista realmente preocupada com uma possível atitude autodestrutiva do paciente. Principalmente porque a intenção de suicídio não era um assunto falado pelo paciente durante os primeiros anos de análise. A questão que inquietava constantemente a analista era como lidar com essa cadeia de identificações cruzadas, ou seja, as identificações narcísicas que se produziram em Eugênio devido ao narcisismo atrapalhado de seus pais. Narcisismo que atravessou o limite do eu- não eu, adentrou o ego do paciente como uma invasão aniquiladora, produziu um aprisionamento do rapaz num conflito edípico positivo e negativo ao mesmo tempo, provocando um cruzamento de identificações - de uma identificação masculina e outra feminina.

Na teoria freudiana, o superego é o produto do Complexo de Édipo, de acordo com a nossa retomada teórica, e tem sua base numa identificação resultante desse conflito edípico, enquanto o ideal do ego é resultante do narcisismo infantil e de uma identificação edípica. Então, como entender a relação do superego e do ideal do ego se partirmos do pressuposto de 
que são duas instâncias distintas com funções diferentes e específicas a cada uma delas? E se adotarmos a posição de que superego e ideal do ego são realmente instâncias diferentes, como trabalhá-las na condução de uma análise?

Quando o analisando produz uma série de atos falhos em poucos minutos da sessão, falando de seu pai como escolha de objeto amoroso, e não somente como um modelo de identificação, é que nos deparamos com os efeitos da outra gama de identificações derivadas do Complexo de Édipo invertido ou negativo. É esse complexo, do qual acabamos de falar, que verificamos no relato do paciente durante uma sessão na qual a pauta era a relação dele com o pai:

"O problema é que em 95 ele resolveu casar com uma mulher que só queria o dinheiro dele, só porque ele é desembargador. Ela era uma vagabunda, bem vulgar, não trabalhava, não fazia nada e ele me contou tudo, que casou com ela em comunhão de bens porque ela disse que só casaria com ele se fosse em comunhão total de bens. Este foi o erro dele, ter casado de novo afastou muito ele de nós e ele se dá conta disso, falou que nunca mais iria pôr ninguém entre nós. Foi um erro ter posto alguém no meu lugar... A gente se afastou muito. Agora ele tem namoradas, mas diz que nunca mais vai pôr alguém no nosso lugar... Esse casamento foi horrível, eles brigavam e voltavam muito. Parece que eu repeti fazendo mesma coisa com a Eduarda, nosso namoro vai e volta e a gente briga muito... Pior foi quando ele foi se separar e teve que dividir tudo o que era nosso com ela, a casa da praia, o apartamento que a gente mora. Daí ela não queria mais que a minha mãe fosse na casa da praia, foi horrível. Eu е о meu filho..., me enganei, eu quis dizer eи е о meи irmão.” (Eugênio). 
Quando indagado sobre a frase de que o pai, ao casar, teria colocado alguém em seu lugar, Eugênio reage com surpresa e uma dose de susto, mas tenta negar o significado desse ato falho, afirmando ter se tratado apenas de um equívoco de linguagem. Segue seu raciocínio e, na frase seguinte, troca intencionalmente as palavras "no meu lugar" por "no nosso lugar", referindo-se a ele e ao irmão, como se assim conseguisse evitar ter de se deparar com o que significava o que ele havia dito. Ao mesmo tempo em que tentava esconder de si mesmo o que o seu inconsciente estava gritando - o efeito das identificações cruzadas no exercício da sua sexualidade - o seu inconsciente pulsava cada vez mais forte na tentativa de ser escutado para encontrar uma saída. Seu desconcerto diante da intervenção da analista, que simplesmente repetiu as palavras dele em tom de indagação, revelando as marcas do seu desejo inconsciente, são reafirmadas em seguida num outro ato falho - "eu e o meu filho" quando conscientemente pensava em referir-se a ele e seu irmão. Ou seja, na fantasia, o irmão mais novo era produto de uma relação incestuosa homossexual de Eugênio com o pai. O fato clínico que trazemos, nesse momento, escancara um aprisionamento no Complexo de Édipo invertido, que nos ocupou por um longo tempo da análise, até que pudéssemos elucidar e historiar esse romance familiar, desemaranhando o complexo campo das identificações narcísicas com a mãe e com o pai.

Referimo-nos anteriormente que no texto Leonardo da Vinci (Freud, 1910/1990) já havia um uso, por parte de Freud, do modelo de identificação narcísico para explicar a homossexualidade. Nessa época, já havia formulado uma definição de narcisismo, que seria uma fase intermediária entre autoerotismo e o amor objetal. Suspendemos temporariamente as questões do paciente com o pai, mesmo com a resistência de Eugênio e sua insistência em dizer que o pai era o seu único problema. O sentimento de culpa do início do tratamento, os atos falhos reveladores de uma atitude passiva frente ao pai, e o fato de ele dormir com a mãe 
nos levam a pensar na relação que ele teve com esta mulher, sob a perspectiva das identificações provenientes do Édipo positivo.

Evidentemente que podemos pensar, assim como devia pensar o próprio paciente, que tudo de pior já havia lhe acontecido e já tinha sido revelado, mas, em se tratando de Eugênio, ainda tínhamos coisas desconcertantes a escutar. Por muito tempo, o paciente, quando se referia à mãe, em poucos momentos na análise, chamava-a de santa, de mulher maravilhosa, que abriu mão de sua carreira para cuidar da casa e dos filhos. Levou muito tempo para que o paciente contasse o fato de que desde a separação dos pais dormia com a mãe na cama, como já falamos. Ao tratar da gênese da homossexualidade masculina, Freud (1910/1990) observa que os indivíduos haviam tido uma ligação erótica intensa com uma mulher, geralmente sua mãe, durante o primeiro período de sua infância, esquecendo depois esse fato. Essa ligação havia sido despertada ou encorajada com demasiada ternura por parte da própria mãe, e reforçada posteriormente pelo papel secundário desempenhado pelo pai durante a infância.

O primeiro período da infância de Eugênio estava sob o efeito do recalcamento, mas, com o tempo, ele começou a revelar a relação de proximidade intensa com a mãe, quando contou que dormia na cama com ela desde a separação dos pais. Certo dia, quando falava de sua impotência sexual com Eduarda, ele conta uma cena que o deixou horrorizado. Esse fato clínico ocorreu durante o tempo em que já estava em análise e que, mesmo pertencendo ao segundo tempo de sua vida sexual, nos permite pensar que outras cenas de sedução devem ter ocorrido para que o paciente se refugiasse numa identificação narcísica e homossexual, como defesa de um possível incesto. Eugênio, aos prantos, conta que uma noite estava saindo do banho e dirigia-se ao seu quarto para se vestir - o que já nos comunica que, de hábito, as pessoas andavam nuas pela casa - quando, no pequeno percurso do banheiro ao quarto, a mãe passa por ele e comenta: "Coloque ao menos uma toalha quando sair do banho, meu filho. 
Ou você acha que a gente vê um homem pelado e não sente nada? Você acha que eu não me excito?"

Ainda que a frase da mãe seja um pedido de que o filho cubra o corpo como uma barreira ao incesto, ela faz questão de comunicar ao filho que ele a excita, numa atitude sedutora transgressiva. O rapaz fica desesperado ao escutar essa frase e é nesse momento que ele começa a pensar em se mudar da casa da mãe e nos recursos que disporia para isso. Se uma mãe tem essa consciência de sua excitação e a explicita sem pudor algum ao filho, podemos inferir que devem ter existido outras tantas cenas em que ela promovia esse tipo de sedução. Como nos afirma Chasseguet-Smirgel (1992), pode haver muitas consequências como resultado da tentativa de escapar às investidas perversas da mãe, entre as quais a religião. No primeiro momento, presenciamos uma inversão do Édipo como defesa contra o convite caloroso da mãe, talvez único recurso de que Eugênio dispunha na primeira infância. Estabelece-se, então, uma identificação narcísica com a mãe na qual ele próprio passa a ser o modelo de amor que irá buscar nos objetos substitutos. Nesse sentido, Freud (1910/1990) afirma:

O amor da criança por sua mãe não pode mais continuar a se desenvolver conscientemente - ele sucumbe à repressão. O menino reprime seu amor pela mãe; coloca-se em seu lugar, identifica-se com ela, e toma a si próprio como modelo a que devem assemelhar-se os novos objetos de seu amor. Desse modo ele transformou-se num homossexual (p. 92).

Quando encontramos na literatura psicanalítica a indicação de que deveríamos levar em conta a existência de um Complexo de Édipo completo, ou seja, positivo e invertido, Freud (1923/1990) referia-se à predominância de um ou de outro, sendo um mais consciente e outro mais recalcado na hora da dissolução do complexo. O que temos é que o resultado dessa fase sexual é um precipitado no ego dessas duas identificações, positiva e negativa, unidas 
uma com a outra; estas modificações no ego reteriam uma posição especial que seria o superego. No caso de Eugênio, as duas identificações resultantes do Édipo positivo e do Édipo invertido alternavam-se, predominando em certo momento uma ou outra, ambas inscritas nos registros das intensidades. Entretanto, a literatura psicanalítica também define que o superego não seria uma instância tão simplesmente herdeira do Complexo de Édipo. Além de ser resultante desses resíduos das primitivas escolhas de objeto, o superego representa uma formação reativa enérgica contra essas escolhas. Ao mesmo tempo em que existe a identificação dizendo "você deveria ser assim", existe a proibição que determina que o sujeito não pode ser como o pai, pois não pode fazer tudo o que ele faz.

No texto Dissolução do Complexo de Édipo (Freud, 1924/1990a), há duas perspectivas de satisfação para a criança que está em pleno conflito edípico: uma ativa e uma passiva. Ela poderia colocar-se no lugar do pai, numa atitude masculino-ativa, e ter relações com a mãe, caso em que o pai seria um estorvo, ou poderia querer assumir o lugar da mãe e ser amado pelo pai, numa atitude passiva. Eugênio, quando percebe que a relação com a mãe está próxima demais, e que o pai não está presente para fazer o papel de estorvo, interditando o incesto, encontra na identificação com a mãe a salvação para barrar o incesto. Nesse momento, nos deparamos com mais uma prova de que, nesse caso clínico, ser homem é equivalente a ser criminoso. Se ele for homem, irá transar com a mãe, portanto ele arranja um jeito de não ser, que é identificando-se com ela.

Ainda nesse texto, encontramos a explicação de que, no caso da menina, a renúncia ao pênis não é tolerada sem tentativa de alguma compensação. Então, seu Complexo de Édipo culmina num desejo de receber do pai um bebê como presente, numa equação simbólica que desliza do desejo do pênis para o de um bebê. O paciente, quando contava a cena do pai que atropela alguém, por conta da briga com a ex-esposa, comete outro ato falho que não deixa dúvidas da inversão de suas identificações, "eu e meu filho" (Eugênio), ao invés de dizer "eu 
e meu irmão". Nesse episódio, ele assume claramente a identificação com a mãe e admite, ainda que inconscientemente, o desejo de receber um filho do pai, completamente identificado com a mãe.

O sentimento de culpa consciente é algo compreensível e fácil até para os leigos. Trata-se de uma tensão entre o ego e o superego, sendo o primeiro massacrado pelo segundo. O que Eugênio anuncia na primeira fala da análise, que marcamos como sendo a parte da culpa de que tinha consciência, era a culpa característica dos quadros de neurose obsessiva, nos quais o superego condenou o ego com severidade. Outra parte, porém, permaneceu por um longo tempo da análise ainda inconsciente, que é aquela culpa possivelmente ligada ao suposto parricídio, crime que tinha cometido em fantasia - e ligado à questão da masturbação infantil, como afirmou Freud em 1924(/1990). Esta questão leva a um tipo específico de masoquismo, que nos interessa aqui, que é o masoquismo moral.

No texto Uma criança é espancada (Freud, 1919/1990b), há uma passagem que anuncia a ideia de que o problema da culpa não deriva exatamente da masturbação infantil, mas sim da fantasia que a acompanha. O sentimento de culpa inconsciente é percebido pelo ego como necessidade de punição, como Freud mostrou no trabalho do Masoquismo (1924/1990c). A crítica é a manifestação do superego e a necessidade de punição é o efeito desta no psiquismo. Esse sentimento de culpa inconsciente pode se tornar o maior entrave no processo de cura de uma análise, mostrando sua face como reação terapêutica negativa.

Tratamos há pouco da questão que explica como que, do ponto de vista pulsional, o superego pode ser tão cruel quanto só o id pode ser; dissemos que isso acontece devido à identificação narcísica, na qual o objeto foi incorporado ao ego, deixando assim a pulsão de agressão sob domínio do superego. Desse modo, quanto mais o sujeito tenta controlar sua agressividade para o exterior, mais severo e agressivo será com o seu ideal do ego. Também esclarecemos como a pulsão de morte é inserida no superego, trabalhando as ideias de Freud 
(1923/1990) segundo o capítulo cinco desse texto no qual a pulsão de morte é descrita como resultante da desmescla pulsional que ocorre durante a identificação com o pai tomado como modelo. Repetimos aqui que, segundo Freud, nesse tipo de identificação resulta um quantum de componente erótico que não mais se pode ligar à pulsão de vida à qual estava combinada, e essa pulsão de morte restante ingressa no superego, sendo o responsável pelo caráter cruel dessa instância.

O texto Masoquismo (Freud, 1924/1990c) confirma a ideia, que resgatamos no parágrafo acima, segundo a qual é graças e essa desfusão das pulsões no momento da identificação narcísica que a severidade do superego fica aumentada. Isto confirma a nossa hipótese anterior de que esse parágrafo que fala da desmescla pulsional diz respeito à constituição do superego e não da sublimação, nos permitindo usá-lo para lançar luz sobre uma das questões dessa investigação: a origem da severidade do superego na presença da pulsão de morte nesta instância.

A agressividade é outro tema que sempre ocupou a mente de Freud e agora toma o primeiro plano da nossa atenção. Em Mal-Estar na Civilização (Freud, 1930/1990) há um capítulo dedicado a discutir como o homem domina a sua agressividade e a relação da agressividade com o sentimento de culpa, que é a expressão do superego severo. Conhecemos duas origens do sentimento de culpa: o primeiro é o medo da autoridade, que se descobrir a atitude má do sujeito infringirá uma penalidade deixando esse sujeito desamparado e desprotegido pela perda do amor. Transar com a mãe é uma atitude má e proibida, que faria Eugênio perder o amor do pai, enquanto matar já é uma questão que o confundia, pois, por mais que a autoridade legisle que isso é proibido, no caso do analisando esse crime está autorizado pelo próprio pai. Não por acaso a autoridade da família do paciente também é um representante da lei na cultura, um desembargador. Esse complicador atravessa a vida de 
Eugênio, pois a autoridade que legisla o que pode e o que não pode, o que é mau e o que é bom, é o próprio pai, que foi condenado como um homicida.

O segundo fator que origina o sentimento de culpa, posterior ao medo da autoridade, é o medo do próprio superego que, por encontrar-se próximo do id, tem uma parte inconsciente, como já vimos. Portanto, nada pode ser escondido dele, nem sequer as intenções - ao contrário do que se passa com o ego, no qual as coisas podem ser recalcadas e escondidas -, fato que levava ao temor e ao desejo de suicidar-se.

Há diferença entre as duas origens do sentimento de culpa: na primeira situação, uma renúncia das pulsões é exigida, ao passo que, na segunda situação, o que se exige é uma punição, pois do superego nada fica escondido. A pessoa sente-se culpada mesmo quando não cometeu uma ação má. O simples fato de ter tido a intenção de cometer uma ação má já leva à culpa.

Ainda que Eugênio não tenha efetivado o incesto, nem cometido o parricídio, conforme pulsava o seu desejo, o fato de ter tido essa intenção foi o suficiente para seu superego perceber e ele sentir-se inconscientemente culpado e necessitar de punição. Não conseguir manter uma ereção durante as tentativas de manter relações sexuais com a namorada parecia ser uma punição do superego por ter desejado transar com a mãe, como se o superego tivesse voz e dissesse: Você almejou o prazer máximo! Agora ficarás impotente! Outras tantas cenas de punição foram contadas pelo paciente, na maioria cenas em que ele dizia que se "colocava de bunda" (Eugênio) para se ferrar. Com frequência, ser ferrado pelo pai, a exemplo de quando este o deixa à mercê de uma mãe perversa, como se o menino tivesse que fazer o que ele, pai, não fazia com a mãe. Outro exemplo, como veremos mais adiante, é o momento em que o pai convoca Eugênio para resolver os problemas familiares do homicídio cometido pelo primo. 
Encontramos numa conferência que nunca foi proferida (Freud, 1933/1990), mas foi escrita com intuito de divulgar a psicanálise aos leigos, uma explicação de que os pais geralmente são severos e exigentes ao educar os filhos, esquecendo-se de suas próprias dificuldades na infância. Isso explicaria o superego de uma criança como o efeito dessa educação, constituindo-se segundo o modelo do superego dos pais e não dos próprios pais em si, e tornando-se os portadores das tradições através das gerações. De certo modo, essa explicação é pertinente ao caso que estamos examinando, pois os conflitos são passados ao longo de três gerações - avô, pai e filho -, sendo que todos padecem da severidade do superego. Porém, há outra explicação no texto de Freud de 1930(/1990) sobre a origem da severidade do superego que difere um pouco dessa que encontramos em 1933(/1990), reforçando que, no tocante às questões teóricas do superego, Freud acaba sendo ambivalente ou confuso, com afirmações diferentes em momentos diversos da obra.

A outra explicação a que nos referimos parte do ponto de vista de que a criança deve ter desenvolvido uma quantidade considerável de agressividade contra a autoridade que o impediu de realizar suas primeiras satisfações. Vendo-se obrigada a renunciar também a essa agressividade, a criança lançaria mão do mecanismo já descrito por nós da identificação que incorpora o objeto no ego, introjetando a autoridade externa que se transforma no superego e apossando-se de toda agressividade disponível até então. A relação do superego com o pobre ego seria um retorno da relação da autoridade com a criança, porém agora invertido: o superego como a criança que exerceria toda a sua ira contra o pai, que está, então, introjetado no ego. Assim, a severidade original do superego não seria representante tão direta da severidade dos pais na educação dos filhos, mas sim da própria agressividade da criança contra os pais. Esse impasse foi resolvido quando Freud (1933/1990) admitiu que, na verdade, as duas formas de severidade do superego, tanto a advinda da severidade do superego dos pais, quanto à da própria agressividade da criança que foi voltada para o ego, coexistem, 
sendo que, em certos casos, predomina uma origem, e, em outros, talvez observemos melhor a outra possibilidade.

\subsection{Ser um Grande Homem ou um Criminoso?}

“Sua lâmpada! Sua toalha! Seu prato!” (Freud, 1909/1990, p.208).

Ernst Lanzer é o verdadeiro nome do paciente de Freud conhecido como Homem dos Ratos, por conta da passagem em que este fica sabendo de um castigo corporal que consistia em amarrar um criminoso e virar em suas nádegas um vaso com alguns ratos - os quais cavavam um caminho no ânus do sujeito (Freud,1909/1990). Uma curiosidade, que em nada modifica o conteúdo da cena descrita, é que em Freud encontramos o relato de Ernst sobre o castigo como se alguns ratos fossem colocados no vaso, enquanto que na pesquisa minuciosa feita por Mahony (1991), nos originais do Freud, encontramos a descrição do castigo ocorrendo com um rato apenas, que teria sido provocado e enfurecido com uma varinha, para deixar o bicho ainda mais agressivo. Lanzer foi diagnosticado como um neurótico obsessivo grave, visto que precocemente experimentou satisfações sexuais, as quais geraram obsessões e autopunições pelo prazer que experimentou na primeira infância.

Em consequência dessas experiências, algumas com a babá, outras derivadas de suas masturbações infantis, o pai de Ernst repreendeu-lhe duramente por uma má conduta ligada à masturbação quando o menino tinha menos de seis anos - segundo a mãe dele, por volta de três ou quatro anos. A hipótese freudiana é de que esse castigo havia posto fim à masturbação do pequeno, porém, tinha deixado atrás de si uma ferida que gerava um rancor inextinguível pelo seu pai, que ficara para sempre como o perturbador do seu gozo sexual. O paciente de Freud confirma essa inferência ao relatar uma cena de que ele próprio não se lembrava, mas que foi contada muitas vezes por sua mãe, em função das consequências geradas pelo 
episódio (Freud, 1909/1990). Certa vez, Ernst praticara uma travessura e seu pai lhe batera: O pequeno foi tomado de terrível raiva e xingara seu pai ainda enquanto apanhava. Entretanto, como não conhecia impropérios, chamara-o de todos os nomes de objetos comuns que lhe vinham à cabeça. Assim, gritava: "Sua lâmpada! Sua toalha! Seu prato!” (Freud, 1909/1990, p. 207). A reação do pequeno assustou o pai, que imediatamente parou de bater-lhe e, surpreso, exclamou: "O menino ou vai ser um grande homem, ou um grande criminoso!" (Freud, 1909/1990, p. 208). Esse episódio não passou livre de consequências para ambos os personagens. O pai de Ernst nunca mais lhe bateu e o paciente acreditou que essa cena tenha alterado seu caráter transformando-o num covarde, pelo medo da violência de sua própria raiva.

Certamente, poderíamos traçar várias semelhanças entre Eugênio e o Homem dos Ratos. Ambos tiveram uma proximidade muito intensa com uma mulher nos primórdios da vida, Eugênio com a mãe e Ernst com a babá. Este último, frequentemente, escondia-se embaixo da saia da moça para chorar e acabava manipulando seus genitais. Os dois pacientes estão, de algum modo, sob o efeito da atividade das figuras de autoridade, mas não ocupados com a legitimidade da lei. Os homens da família de Eugênio encontravam-se vinculados a altos cargos de poder do direito, enquanto que os homens da vida de Ernst exerciam as funções militares. Aqui precisamos fazer uma ressalva de que os militares estão ligados ao autoritarismo, ao passo que o direito está na ordem do julgamento, daquilo que é certo e daquilo que é errado. Ambos afirmavam que seu problema residia na relação com o pai e quase não falavam da mãe. A raiva recalcada da figura do pai é evidente nos dois e geradora de autocensuras e autopunições severas, comportamentos também semelhantes nos dois casos, embora numa intensidade muito menor em Eugênio. Os dois, em fantasia, consideram-se criminosos: o nosso analisando sem consciência disso, enquanto Ernst tinha total clareza 
desse pensamento. Mas o que mais nos chama atenção é a ideia de destino presente nesses casos, de que se não fizessem tal coisa, algo de horrível aconteceria.

Apesar das várias aproximações possíveis entre os casos clínicos, nosso interesse no texto Notas sobre um caso de neurose obsessiva (Freud, 1909/1990) não é exatamente comparar os dois casos e pensar Eugênio na perspectiva unicamente da neurose obsessiva. Isso empobreceria muito a discussão que estamos formulando sobre o valor das identificações na constituição do ideal do ego e do superego. A ideia é internalizarmos certos elementos do caso clínico apresentado por Freud, para trabalharmos algumas das questões levantadas até agora, a partir do campo do narcisismo, das identificações e do superego, pela via do amor de transferência. Assim, será possível pensar em como retirar o Eugênio do lugar de destino, de que se não pagasse a dívida familiar algo de terrível iria lhe acontecer. Esse é o motivo pelo qual agora nos debruçamos na passagem do pequeno Ernst, que esboça sua ira contra o pai durante uma surra, como anunciamos no início desse ponto.

A intensidade da raiva do menino era tão grande que ele se assustou com a violência manifestada em si mesmo. Bleichmar (1985) trabalha a ideia de que os enunciados identificatórios contêm enunciações que precisam ser entendidas e discriminadas, para que o sujeito não fique aprisionado em identificações narcisistas. $\mathrm{O}$ enunciado do pai de que o paciente seria um grande homem ou um criminoso continha duas enunciações que ficaram indiscriminadas para Ernst. A nossa questão se refere ao seguinte: o que faz o sujeito escolher um caminho ou o outro? Ainda que culturalmente os caminhos tomem cunhos bem diferentes, um aceito e outro renegado, respectivamente, ambos têm algo comum em sua dinâmica.

Para ser um grande homem, o sujeito precisa ser um transgressor, pois é uma busca por algo idealizado. Assim como ser um criminoso também contém algo de idealização e de transgressão, pois o criminoso faz a sua própria lei, como se estivesse acima da lei dos homens. Certamente esse episódio fez com que, a partir dali, Ernst estabelecesse uma 
identificação com bases narcísicas com o pai, renunciando a este como objeto, mas ficando fixado em seu modelo e, assim, não rejeitando o seu amor por ele. A identificação narcísica permite ao sujeito criar uma vicissitude pulsional à agressividade. Neste caso, é a volta contra si mesmo, como descrita em 1915(/1990), fazendo com que o paciente de Freud passasse a se agredir com autopunições para proteger o próprio pai de sua raiva (Freud, 1915/1990a).

Eugênio possivelmente se encontra bastante perdido e atrapalhado com as enunciações que estavam colocadas nos enunciados transmitidos nas identificações com pai e com a mãe. A indagação de Eugênio sobre se seria um grande homem ou um criminoso era perturbadora e recorrente em seus pensamentos. Obviamente que não era formulada com essas palavras, mas o episódio do pai de Ernst batendo nele nos empresta esses enunciados que se encaixam na problemática de Eugênio. No caso do paciente, esse questionamento aparecia na forma de dúvida quanto a sua própria escolha profissional. Por um longo tempo do tratamento o analisando indagava-se sobre o seu rumo, pois era mais um a cursar a faculdade de direito. Pensava que se fosse desembargador, que era o cargo idealizado na sua família, como se outras funções dentro dessa disciplina não tivessem valor, certamente o enunciado de que uma tragédia se abateria sobre ele seria confirmado e ele, então, se tornaria um criminoso.

Nesse tortuoso período de tempo, o paciente tomava-se de angústia sempre que pensava na questão profissional. Talvez pudéssemos pensar que o curso de direito era um sintoma resultante de uma identificação histérica, a qual, como já dissemos, faz um sujeito identificar-se com o desejo do outro e formar em si o mesmo traço do sujeito imitado. Avô, pai e filho, todos tinham em comum a intenção de cursar direito para ser desembargador, buscando à margem do psiquismo uma lei que os protegesse do intenso movimento parricida. Configurando o curso de direito um sintoma, o destino de Eugênio estaria confirmado se concluísse a faculdade. O conflito simplesmente traduzia a impressão de que as escolhas estavam na ordem de que ser homem era equivalente a ser criminoso. 
Durante o ano de análise em que a vida profissional foi a pauta, o paciente fez o movimento de buscar cursos de teatro, oficinas de literatura, tentou vestibular para as faculdades de jornalismo e de comércio exterior, pensando que a saída era não ser um profissional do direito, ainda que gostasse deste curso. A partir das oficinas de literatura surge o elemento novo na análise, os contos de Eugênio, que surpreendem a escuta. No início eram os contos que ele já tinha escrito antes do início do tratamento. Mas, com a receptividade aos seus textos na análise, ele buscou um curso para aprimorar a escrita de contos e passou a produzir novos textos com base nos conteúdos trabalhados. Até esse momento do tratamento, encontravam-se sobrepostas as ideias de que ser homem era ser criminoso. Exatamente como o pai de Eugênio, que conseguiu a proeza de ser as duas coisas. Ele era um modelo de ideal para o filho no que diz respeito à profissão que exercia, sendo considerado como desembargador um grande homem, e, ao mesmo tempo, um homicida.

Freud (1909/1990) levanta a questão de que o pensar obsessivo diz respeito a mais do que meras considerações racionais. Chega a ser um pensamento delirante, e seu espectro só desaparece quando o sujeito transforma a ideia obsessiva em destino. Enquanto o sujeito continuar cometendo uma má ação, algo maligno acontecerá a alguém de quem goste muito. A dúvida obsessiva entra como um elemento do qual a neurose se utiliza a fim de lançar o paciente para fora da realidade e, assim, isolá-lo do mundo. Com isso promove uma introversão da libido até certos pontos de fixação.

Eugênio não conseguia perceber que poderia ser um profissional do direito como qualquer outro, sem precisar exigir de si ser um grande homem, e, assim, desidealizar a profissão, colocando o direito no lugar de uma simples faculdade como qualquer outra, que fornece os instrumentos para o exercício de uma profissão. Era necessário romper a identificação estática com o pai para dissolver essa identificação com os impulsos homicidas deste e assim escolher o direito para ser um profissional. A questão é que ser um grande 
homem ou um criminoso passa pela interpretação que o sujeito possa dar às enunciações incorporadas por meio das identificações estabelecidas no complexo paterno. $\mathrm{Na}$ identificação, transladam-se atributos, traços e valorações, e, para obter as valorações, tem-se que incorporar os atributos. (Bleichmar, 1985).

Do nosso ponto de vista, trabalhar o conceito de identificação exige uma incorporação do valor que existe no outro - nesse caso clínico, a violência. Ao se movimentar para fazer um investimento na identificação com o pai, constituindo-se como pessoa e como homem, Eugênio encontra uma matriz rota. O pai, um desembargador que por baixo da toga era um alcoólatra, assim definido pelo próprio filho, e homicida condenado e definido pelo tribunal do júri, transgredia as leis que ele mesmo representava. Voltar-se para a mãe era igualmente caótico, na medida em que a mãe explicitava a excitação que o filho provocava. Então, temos identificações que transmitem enunciações de que o filho está liberado para ser um criminoso ou um perverso.

Quando Freud (1909/1990) trabalha a questão da dúvida obsessiva, o faz no sentido de elucidar que a dúvida é quanto ao próprio amor. Saber se é amado é algo que deveria ser a coisa mais exata na mente do obsessivo. E essa dúvida toma proporções que acabam por afetar tudo o mais de suas vidas. Não é à toa que Eugênio tem uma imensa dúvida quanto ao amor de seus pais por ele. Desde o início da vida, se percebe na história de Eugênio que as identificações primárias fizeram o menino incorporar uma potencialidade cruel, que se justapõe com o excesso advindo dessas realidades que revigoraram a crueldade do superego na introjeção das identificações secundárias. Ao mesmo tempo em que o pai se mostra como o criminoso que é, a mãe estimula este potencial cruel. Portanto, mais do que desamparado, talvez Eugênio se sentisse órfão no encontro com essa dupla parental. Eugênio busca na análise uma tentativa de reorganizar a complexidade do seu processo identificatório e, assim, reconhecer-se em um lugar conquistado de valor próprio. 
A dúvida desse amor parental ficava atualizada no questionamento sobre o amor de sua namorada por ele, o que gerava profunda insegurança e angústia no rapaz e era motivo de constantes conflitos e brigas com Eduarda. Recriminava-se de que, se continuasse sendo ciumento, possessivo e bravo, algo de ruim iria acabar lhe acontecendo, pois a namorada o deixaria, em consequência, enlouquecido a ponto de cometer um ato desmedido. Ainda não mencionamos que a namorada também era estudante de direito, o que nos leva a concluir que a escolha por essa moça não se deu ao acaso, mas como efeito de uma armadilha edípica na qual Eugênio, tomado pelas cenas excessivas que vivia passivamente, estava aprisionado. Eduarda representava todos os conflitos descritos até aqui, causadores do sofrimento do paciente e de sua impossibilidade de ser ativo.

Aparentemente sem saída, o paciente pensou, num primeiro momento, em se tornar religioso para alterar o destino da família. Mas, agora, podemos ampliar a compreensão desse desejo do paciente, a partir do enunciado que o pai do Homem dos Ratos nos empresta, de que um neurótico obsessivo pode ser um grande homem ou um criminoso. Se ser um grande homem é tão idealizado quanto ser um criminoso, e nos registros do paciente ser homem só sendo criminoso, ele encontra a saída religiosa como a ideia de que é possível ser sem tornarse criminoso. Assim, estaria livre de se tornar um desembargador homicida, bem como de confrontar-se com os problemas relativos a uma vida amorosa, pois Deus asseguraria seu lugar de filho amado incondicionalmente.

“Tem mais uma coisa que nós ainda não conversamos que é sobre religião, mas agora eu já posso te contar. Bem, tu sabes que eu sou católico. Quando eu entrei na faculdade, um professor que dava aula levantou o assunto de religião um dia e percebeu que eu era bem católico. Aí no final da aula ele veio falar comigo e disse que ele conhecia um padre que era do Opus Dei, que é um movimento que existe 
dentro da Igreja Católica do qual as pessoas são convidadas a participar. Passaram uns dias e esse padre me ligou, conversou comigo e me convidou a fazer parte desse movimento e eu comecei a participar. (...) Só que eu comecei a ficar confuso, teve uma hora que aquilo estava mais me deixando confuso do que me ajudando. Eu não sabia mais o que eи queria, o que eu tinha que fazer, o que eu podia fazer. Eu pensava que eu queria ser padre, mas estava confuso. Foi logo depois que eu comecei a vir aqui que eu estava muito confuso. Eu não te falava porque eu nem sabia o que dizer. Só que aos poucos eu comecei a vir aqui e a gente foi tratando outros assuntos e na medida em que a gente ia conversando eu também ia pensando nisso. Mesmo que eu não te falasse diretamente sobre esse assunto tu me ajudaste muito nisso. Eu fui vendo que eu tenho a minha vida e que eu quero viver ela e lá eu teria que abrir mão disso. Até de namorar, o padre não dizia que eu não podia namorar, mas tinha que ser um namoro casto, não podia nem transar com a Eduarda." (Eugênio).

Desde o princípio dos encontros, Eugênio deixava implícita a questão da religião, e, num único momento, afirma que pensava em ser padre. Em outra sessão, ele confirma que já estava mais tranquilo e poderia falar sobre o assunto. Isso se deu depois de começarmos a discriminar as enunciações das identificações de sua história, e trabalhar a ideia de que aos 21 anos ele poderia diferenciar-se do pai e da mãe e ser ativo - contrariando o vivido na infância, quando não tinha recursos nem alternativa a não ser sofrer passivamente. Ele pôde, então, começar a desidealizar o direito e questionar os arranjos que pensava serem sua única saída.

O tema da religião foi introduzido na sessão por meio da leitura de um conto, escrito num momento em que estava deprimido com o "acidente" do pai, na manhã seguinte a esse episódio. Certamente a analista percebeu a presença do tema, pairando implicitamente, durante quase todas as sessões daquele primeiro ano de análise. Entre as tantas coisas que 
tivemos oportunidade de aprender com Eugênio, uma delas foi ter paciência e aguardar que o paciente, quando quisesse, falasse, respeitando o seu o tempo. Escutando sua longa história, de suicídios, homicídios e convites incestuosos, e questionando se realmente esses destinos que ele conhecia eram os únicos que existiam, ele, ainda que sozinho, uma vez que não falava sobre a religião, e mesmo acompanhado pela analista, pôde decidir abrir mão do caminho religioso e pensar na possibilidade de criar outros ideais do ego para si.

Após a decisão de abrir mão do ideal de ser padre, o paciente pôde contar brevemente o que é o Opus Dei, embora poupando a analista e a si próprio dos detalhes que talvez mais o assustassem quando pensava na escolha que havia feito até então. Na voz do paciente, o Opus Dei é um movimento dentro da Igreja Católica para difundir a religião, no qual apenas se lê e se discute textos de filosofia, teologia. Além disso, cada membro tem um orientador espiritual, com quem deve encontrar-se uma vez por semana para se confessar, comungar e receber orientações sobre a vida no geral.

Numa reportagem da revista Superinteressante (2006) que teve como capa o Opus Dei, encontramos explicações bem mais rígidas e severas do que as dadas por Eugênio. A reportagem transcreve as palavras do fundador desse movimento, que o define como "uma injeção intravenosa na corrente sanguínea da sociedade" (Botelho, 2006, p. 57), que difundiria a "obra de Deus". Seria um movimento que objetivava preparar mentalmente indivíduos católicos, porém laicos, da sociedade, para que estes divulgassem “os julgamentos” de Deus. Essas pessoas deveriam ir à missa sete dias da semana, todos os dias do ano, além de se confessar semanalmente e obedecer fielmente ao papa vigente.

O artigo levanta ainda a questão mais delicada do movimento, que é a de que seus membros deveriam se autoflagelar, num culto ao masoquismo. O exemplo apresentado na reportagem a que me refiro foi do penitente "monge" Silas, do Opus Dei, retratado no Código Da Vinci, do autor Dan Brown, que utilizava vários instrumentos de autoflagelação, até 
conseguir sangrar. Alguns religiosos se defenderam na época dizendo que no Opus Dei não havia monges e que havia certo exagero nessa retratação, que esse não era o objetivo do movimento, e que eles usavam em algumas ocasiões apenas uma corda com nós, que nem deixava marca alguma (Botelho, 2006).

Se pensarmos na severidade pregada por esse movimento católico, e mais precisamente nos castigos corporais que supostamente existem, nos aproximamos do castigo dos ratos do caso de Freud. Já dissemos que a religião era, na ideia do nosso paciente, a saída para ser um grande homem. Mas se pensarmos na sua neurose, podia ser a ilusão da completude narcísica com Deus, e de proteção contra a orfandade psíquica que ele experimentou ao longo de toda a vida. Seria uma forma inconsciente de pagar a dívida neurótica do obsessivo e assim ficar livre do destino maligno? O Futuro de uma Ilusão (Freud, 1927/1990a) é um texto que reaproximou Freud de um antigo interesse, que era o tema da cultura, já presente em sua obra em 1908, quando se questionava sobre os caminhos tomados pela civilização às expensas da sexualidade. Em 1927(/1990), aborda novamente a questão da renúncia à satisfação das pulsões, só que agora à custa de uma ilusão religiosa. Uma ilusão não é a mesma coisa que um erro; tampouco é necessariamente um erro (Freud, 1927/1990a).

Chasseguet-Smirgel (1992) afirma que celebração religiosa se superpõe facilmente ao cerimonial perverso, não somente pela semelhança de que ambos se apresentam por meio de um ritual, mas também pela idealização que lhes é comum. Quanto à semelhança entre os ritos religiosos e os rituais perversos, o caso de Eugênio mostra que precisamos ir com calma nas interpretações. Situar-se como analista numa interpretação da cultura é uma posição perigosa, pois, por trás de atos perversos, sempre tem uma história que precisa ser escutada. Se a religião para Eugênio estava a serviço de uma ilusão narcísica, de resolver sua neurose, ou na ordem de uma formação reativa, para não psicotizar diante das perversidades dos pais, 
isto era um dado que precisava ser historiado para retirá-lo do aprisionamento narcísico em que se encontrava. Podemos estar sendo violentos e superegóicos ao romper com isso e forçálo a falar dessas cenas ou simplesmente interpretá-lo como perverso. A posição adotada pela analista, de aguardar o tempo preciso e escutar, foi confirmada pelo paciente como uma forma de fazer operar a transferência e colocá-lo em análise.

Nesse ponto, tocamos em duas questões: uma ligada à ética da escuta do analista, e a outra à problemática da transferência. Ora, se estamos tratando do tema dos valores das identificações do superego, e que este tem como uma das suas funções a consciência moral, podemos pensar que a ética é o exercício da consciência moral e pressupõe uma concordância entre o pensar e o agir. A tarefa de escutar exige do analista um longo processo de autoconhecimento que o capacite a identificar e lidar com o efeito dos enunciados a que o paciente se achou subjugado. Afinal, quem de nós não foi constituído a partir do efeito da sexualidade de outro? Não será disso que estamos tratando até agora nessa dissertação, das identificações que deixam o sujeito capturado em certas idealizações? Encontramos os efeitos dos enunciados na própria constituição dos nossos modelos teóricos enquanto analistas, pois é via identificação que introjetamos nossos aportes teóricos e junto com eles os enigmas que nossos mestres nos transmitem. Se não forem elaborados e discriminados, os enigmas promovem um hiato entre o pensar e o agir de um analista. A respeito desses engodos e transferências com os quais um analista pode se defrontar durante sua formação, e, consequentemente, no seu trabalho clínico, Kupermann (1996) escreve sobre as transferências cruzadas. Tais transferências capturam o analista em modelos de ideais, podendo obstaculizar o processo de sua escuta e formar analistas superegóicos - o que em nada nos ajudaria com Eugênio.

No presente caso clínico, se a analista ficasse superegoicamente aprisionada à escuta do conceito, sobre ser um neurótico obsessivo ou um perverso, e interpretasse a religião no 
sentido de uma ilusão, poderia até dizer que teoricamente era disso que se tratava na prática. Estaria fadada a dar o paciente por determinado, sem poder escutá-lo na sua singularidade, inviabilizando sua análise e reafirmando ideais cruéis. A história desse paciente nos permitiu uma identificação com o espírito investigativo de Freud, ou seja, no sentido de pensar que a religião até poderia ser isso que no primeiro momento pensamos, mas que não se tratava disso que o paciente estava nos contando. Ele dava indícios de que confrontá-lo com o assunto da religião o faria desistir da análise. Pois se tratava de uma intervenção precoce que se repetiria na transferência - o lugar narcísico de outro, que não dá conta de si, cruza as fronteiras do eu não eu, e adentra novamente seu ego, não sendo escutado, que era o que ele havia vivido até então. Mais tarde, em sua análise, a investigação sobre o que a religião representava para ele levou à descoberta de que este era o único recurso de vida que teve por um longo período de tempo:

“É que geralmente tu pegas tudo nas entrelinhas, e mesmo às vezes tu não me dando folga tu respeitaste o meu tempo. Às vezes tu dizes umas coisas que parece que está muito rápido para mim, mas no fundo tu vais ao meu tempo e eu precisei desse tempo para confiar em ti. Um exemplo disto é esse assunto da religião. Eu sei que tu deves saber disto há muito tempo, mas deixou que eu falasse quando eu quis sem me tirar o que antes eu ainda precisava para me segurar. Eu fiquei pensando que talvez, por um bom tempo, a religião foi o único lugar onde eu pude me apoiar.” (Eugênio)

Kehl (2002) propõe pensar duas maneiras de abordar as relações entre a psicanálise e a ética. A primeira seria no sentido de uma ética da profissão, ética da psicanálise, que vem ao encontro do que trabalhamos no início da dissertação e que estamos ampliando agora. De proteger os pacientes submetidos a um processo psicanalítico contra possíveis abusos 
cometidos pelos analistas, os quais ocupam uma posição privilegiada no bojo do amor de transferência. A segunda refere-se ao ponto de que a psicanálise não é uma orientadora moral das sociedades ocidentais, pois Freud foi responsável pelo terceiro abalo narcísico da humanidade, quando afirmou que o homem não é dono de si e que é regido por um inconsciente. Nesse sentido, Kehl (2002) afirma:

Melhor falar em nome do isso do que permitir que ele se fale através de mim; por exemplo, na forma de passagens ao ato, pelas quais o eu não consegue se responsabilizar. Melhor admitir a ferida narcísica de me saber habitado por desejos condenáveis do que sofrer de uma culpa inconsciente cuja necessidade de castigo pode me transformar num "delinquente por sentimento de culpa (p. 130).

Em grande parte do tempo da análise, a transferência situou-se num campo positivo que favoreceu o bom andamento do processo. Contudo, não sejamos ingênuos. Se em Freud (1912/1990a) encontramos a definição de que cada indivíduo cria o seu próprio método específico de se conduzir (a vida erótica), na satisfação das pulsões e nos objetivos que determinam a si no decurso, será normal que a catexia libidinal não satisfeita ou parcialmente insatisfeita do paciente seja dirigida à pessoa do analista. O analista será, por sua vez, alvo da transferência do paciente, por meio da qual será incluída nas cadeias ou "séries" que o analisando já formou.

Após liberar-se do compromisso do idealizado encontrado na religião, Eugênio começa a esboçar uma transferência erótica em relação à analista. Quando ocorre esse tipo de transferência, o paciente pode estar utilizando o seu amor a serviço da resistência, como forma de desviar o seu interesse do trabalho e, também, para colocar à prova a severidade do analista (Freud, 1915/1990b). Esse pode ser o momento perigoso de uma análise, que abordamos quando falávamos de uma reação terapêutica negativa. Ao perceber uma melhora, o paciente sente-se culpado e repete na análise os protótipos de relacionamento infantil, 
provocando os analistas a ocupar o lugar cruel ativo que já foi vivido pelos pais. Este é o momento a que se refere Freud em que se coloca à prova o rigor técnico de um analista e o quanto seu narcisismo anda bem regulado.

Entendemos que esse fenômeno ocorreu justamente no momento em que Eugênio abre mão da religião, e, por isso, passa a se sentir liberado para ter intimidade com as mulheres. Ele estaria repetindo experiências de sua primeira infância, agora com a pessoa da analista e, de quebra, evitando deparar-se com o profundo desamparo que o assolava. O paciente encantou-se por três ou quatro moças da faculdade, todas com as mesmas características físicas da analista, e passava o tempo de suas sessões descrevendo-as e o seu encanto por elas. Este também esboçava a fantasia de que se encontrasse a analista em alguma "balada", algo poderia acontecer, afinal a analista deveria ter apenas alguns anos a mais que ele. Durante a sessão também tentava criar um clima de proximidade por meio da literatura, comentava livros que havia lido e que imaginava que interessavam à analista, de autores como Fiódor Dostoiévski e Franz Kafka, e buscava erotizar a relação analítica por meio do pensamento de certos conteúdos.

Uma definição sobre o primeiro tipo de regressão do obsessivo é descrito no texto Notas sobre um caso de neurose obsessiva (Freud,1909/1990) como sendo o processo de agir para o de pensar. Segundo Freud (1909/1990), poderíamos observar nos pacientes obsessivos a revelação quase que invariável de um desenvolvimento precoce e uma repressão prematura da pulsão sexual de olhar e conhecer, observável no Homem dos Ratos, no que se refere a sua babá. O que tornaria o processo de pensamento sexualizado e uma linha de pensamento desenvolvida equivaleria a uma satisfação sexual. A curiosidade de Eugênio a respeito do que gosta uma mulher e o que faria uma mulher gostar dele favoreceu o desenvolvimento desse tipo de transferência. A frequência com que essas situações começaram a aparecer na análise levou a analista a fazer uma intervenção clara e direta, garantindo ao analisando que ali, na 
análise, nada se passaria entre eles, além da fala e da escuta. E que a análise era um espaço no qual tinham proximidade para analisar a intimidade dele.

A nossa experiência clínica, a respeito desse tipo de transferência erótica, confirma a tese freudiana de que nos casos de transferências negativas os pacientes colocam à prova a "severidade" do analista. Preferimos pensar, contudo, em outra palavra que redefina o que Freud (1915/1990b) quis dizer com "severidade" e propomos a palavra rigorosidade, da qual falamos há pouco. Severidade é uma palavra usada por Freud (1915/1990b) no texto Observações sobre o Amor Transferencial, que a nós soa um tanto superegóico, parece contradizer o que acabamos de discutir. Pensar que o paciente teste o rigor teórico e técnico do analista, para dar conta de seus conflitos, nos deixa mais à vontade com a posição recomendada aos analistas nesses casos. Houve momentos em que Eugênio chegou à análise visivelmente excitado. Embora ele não falasse, inferimos que houvesse uma masturbação a partir de fantasias do paciente com a analista, o que podia estar gerando o sentimento de culpa moral, descrito no texto sobre masoquismo. Nesse caso, a reação terapêutica negativa não deixaria de ser uma punição por tais pensamentos.

A atitude adotada pela analista nesse episódio transferencial promoveu um alívio no paciente e o remeteu a pensar sobre dois assuntos a respeito dos quais ele não falava, ou, se falava, não os ligava ao afeto correspondente. O primeiro diz respeito à profunda raiva que sentia do pai, que estava recalcada até então. No dia em que conseguiu se conectar com o seu sentimento pelo pai e verbalizar a frase "eu tenho muita raiva do meu pai" (Eugênio), caiu num longo choro, doído e profundo, que estava trancado há anos. Contou várias cenas na quais se sentia rechaçado, humilhado e desprezado pelo pai. Quando analisávamos essas questões da raiva que ele sentia pela figura paterna, Eugênio introduziu o personagem que anunciamos no capítulo que conta a história desse romance: entra em cena Otávio, seu primoirmão, filho de uma tia, irmã do pai. O pai e o sobrinho costumavam se entender melhor do 
que o paciente com o pai. Até então esse novo personagem havia aparecido em breves referências de suas estórias. Cenas em que ele e seu primo iam jantar na casa do pai e o pai e o primo ficavam o tempo todo fazendo piadinhas de gay, chamando um a outro de peru, passaram a ser comum e isso o incomodava, tanto pela proximidade entre o pai e Otávio, quanto por suas dúvidas sobre sua própria sexualidade.

O namoro com Eduarda estava chegando ao fim depois de quase dois anos de dúvida sobre se deveria ou não terminar essa relação. Tanto para Eugênio quanto para o Homem dos Ratos, decidir sobre a vida amorosa era sempre uma grande questão, quase impossível de ser resolvida, já que esse tipo de paciente superdimensiona o efeito de seus pensamentos hostis sobre o mundo externo. Se terminasse o namoro com Eduarda, talvez denunciasse a raiva que sentia do pai e a morte deste poderia acontecer. Depois de algumas associações entre o pai e a namorada, para analista e analisando era evidente que Eugênio havia estabelecido com esta moça um padrão de relacionamento que reproduzia suas experiências com o pai, que, como já dissemos, o deixava impedido de ser homem. Por isso, a onipotência de pensamentos do seu superego, característica dos neuróticos obsessivos, o deixava tão aflito quanto o fim desse namoro. Queixava-se de ficar passivo e submisso aos mandos da namorada, sentia-se humilhado sexualmente, já que a moça fazia questão de verbalizar o quanto ela era mais experiente e ainda o recriminava por suas escolhas artísticas e literárias, deixando-o numa posição feminina.

Algumas discriminações sobre as enunciações contidas na fala do pai, na noite em que este estava preso na delegacia, começaram a ser possíveis, o que viabilizou ao paciente a decisão e a atitude de terminar o namoro. Retomemos o enunciado do pai do Homem dos Ratos de ser um grande homem ou um criminoso, que, de certo modo, era a ambivalência que os homens da família de Eugênio mostravam. O telefonema do pai para Eugênio na noite do "acidente", chamando o filho de 16 anos para resolver as questões desse episódio, coloca na 
cena as duas enunciações do pai do Homem dos Ratos. Eugênio poderia olhar para essa cena e ver apenas a repetição do destino: primeiro do avô, agora do pai. Mas outra interpretação foi possível. Eugênio poderia olhar para essa cena e discriminar que quando o pai o chama na delegacia de madrugada, para resolver as pendências dessa tragédia, estaria transmitindo a enunciação de que ele, Eugênio, é capaz de resolver os problemas porque tem recursos que o pai provavelmente não o tem. O pai de Eugênio nomeia nesse momento um potencial que percebe no filho, o de resolver os problemas e ser homem sem ser um criminoso. Certamente essa identificação de uma saída potencial existia em algum lugar dentro de Eugênio, a qual, por longo tempo, ficou sepultada, mas que a análise poderia resgatar liberando-o do destino inexorável da sua família.

Evidentemente, paralelamente a isso tudo, o analisando continuou em um questionamento profundo sobre se era homossexual, se sentia atração por homens e se seu problema de potência tinha a ver com não desejar mulheres. Passa um longo tempo às voltas com isso, até que, trabalhando os enunciados e as enunciações das identificações estabelecidas, ele percebe que seu problema não dizia respeito a gostar de homens, mas à falta de um ideal de ego masculino que o ensinasse o que é ser homem, sem ser criminoso. Fica claro para o paciente que sua questão não era ter um homem, mas como SER um homem. Quando essa questão torna-se evidente, o paciente fica muito ocupado de contar cenas em que ele, nas suas palavras, "colocava-se de bunda", com amigos, com a namorada, com o pai e a mãe e percebe que existe outra posição na vida, que é ser ativo, contrariando o movimento de "pôr-se de bunda". É um tempo da análise em que o paciente começa a ter prazer em vir pensar, pois trabalhar essas cenas que ele relatava era desidealizar os pais e assim poder liberar o investimento amoroso que estava represado no ego, por meio da incorporação desses objetos, liberando-o para paquerar, namorar, transar, estudar, criar e, consequentemente, ser ativo. 
Otávio, como já dissemos, é um personagem que ainda viria a ter um papel importante nas vicissitudes que Eugênio daria à sua análise e à sua vida. A dupla analítica não tinha ideia do que ainda estaria por vir, mas hoje, findada a análise, podemos dizer que quando começa haver um segundo movimento de ligação dos excessos, permitindo novas representações, outra cena traumática acontece, colocando novamente dúvidas para o paciente sobre a possibilidade de um novo destino em sua vida. Quando falarmos do episódio do primo Otávio, voltaremos às duas enunciações transmitidas pelo pai a Eugênio: a de um criminoso e a de um potencial que ele via no filho. Provavelmente essa questão nos auxilie na discussão sobre as diferenças do ideal do ego e do superego. Seria então um enunciado de destino superegóico, ser o criminoso, e um enunciado de um ideal do ego, ser um homem capaz de resolver os problemas?

Os questionamentos sobre a homossexualidade, ou melhor, sobre o que é ser homem, nos levou ao caminho da inversão do complexo edípico. A proximidade e a intimidade que ele tivera na infância e na adolescência com a mãe e o efeito disso nas suas identificações foram alvo de longo tempo de sua análise. O paciente admitiu que estar próximo de mulheres era complicado, porque havia tido muita intimidade com a mãe. Várias cenas assustadoras apareceram em suas lembranças. Para Kristeva (2002), a questão do obsessivo não se trata de um trauma real ou psíquico em torno do qual se estruturaria sua neurose, mas de um excesso de excitação que foi separada do pensamento pelo recalque, ficando o afeto livre para a lógica compulsiva da repetição.

A repetição a que Kristeva (2002) se refere é a da relação primitiva oral com a mãe. Ela defende a tese de que Freud, ao privilegiar a fixação anal dos obsessivos, trabalhada por ele por meio do castigo do rato, exclui a importância do erotismo oral que também fica, aos olhos da autora, evidente na devoração que está implícita nessa cena, uma vez que o rato abria caminho devorando o ânus do sujeito. Ela trabalha essa teoria da intensa aproximação erótica 
oral do obsessivo com a mãe, por meio do ato canibalístico na cena dos ratos, bem como de outras cenas nas quais Freud se detém para falar do erotismo anal. A observação sobre o fato de Freud deixar de lado as cenas do Homem dos Ratos com a mãe traz um novo olhar sobre o que até agora havíamos lido desse trabalho.

No artigo O Obsessivo e Sua Mãe (Kristeva, 2002), encontramos uma afirmação da autora que confirma o que até agora havíamos observado na clínica com Eugênio: a de que esses pacientes raramente falavam de sua relação infantil com a mãe, estando, em contrapartida, sempre prontos a evocar os conflitos com o pai e os irmãos. A mãe do neurótico obsessivo seria uma mãe depressiva e, nesse sentido, morta, mas não no sentido da "mãe morta" de Green (2005), que camuflava sua doença com um ativismo exacerbado. Uma mãe que apresenta dois rompimentos: com o pai, de quem ela passa a não ser mais o objeto de desejo, e a quem também não deseja, e com a linguagem. Ela substitui a linguagem por uma intensa troca de olhares, de toques, de cuidados que imprime no filho a marca de uma relação que se satisfaz numa relação muda, na qual o desejo do filho satisfaz a frustração da mãe. Ele se satisfaz com ser o objeto de satisfação da mãe, um segredo que fica sem linguagem e eterno no neurótico obsessivo. Sobre a dissociação da linguagem e do afeto do obsessivo, trazemos um recorte do que diz Kristeva (2002), quando apresenta uma importante indagação:

Dessa maneira, para fazer reconhecer seus afetos, o obsessivo só terá o recurso da violência: violar mulheres - objetos - "sombras"; fazer-se violar como objeto passivo - um animal; romper a carapaça de sua língua e de sua personalidade artificial por uma efração que ele aceita mais facilmente anal, em contrapeso à satisfação oral arcaica que permanece seu segredo inconfessável. Na verdade como pode esse devoto da oralidade fazer um tratamento verbal? (p. 70). 


\section{CAPÍTULO 3 - A ESCRITA, O IDEAL do Ego E OS DESTINOS A PARTIR DE UMA ANÁLISE.}

\section{1 - Contos Traumáticos e o testemunho.}

“Hoje eu trouxe os contos. Ficam para a senhora esses contos. Eu trouxe três, esse da angústia de que eu lhe falei semana passada eu escrevi no dia seguinte do acidente do meu pai. Acidente não, que ele atropelou o cara lá. O outro é um poema, e este último, que eu escrevi há ponco tempo. Eu te contei que no dia do acidente eu tive que acompanhar ele a noite toda, né, foi horrível. Quando eu cheguei em casa de manhã eu peguei um papel e passei a manhã toda escrevendo, foi quando fiz o poema da angústia. Vou ler para a senhora. . . . O outro foi uns meses depois. Eu me inspirei naquele tempo em que os homens eram condenados e iam para a forca, e escrevi como se fosse a confissão de um homem arrependido minutos antes de ir para a forca em praça pública. Não é o meu pai, mas eu fiz falando dele. . . . Tem a ver com religião, e este é um assunto que a gente ainda tem que conversar, né?Este último foi o que eu escrevi uns quinze dias atrás, escrevi depois de uma sessão nossa aqui. Não me lembro sobre o que a gente conversou, mas eu saí daqui pensando muito no que nós tínhamos falado, acho que era sobre eu terminar com a Eduarda e mudar minha vida e quando cheguei em casa resolvi escrever. . Minha mãe diz que é autobiográfico, mas eu acho que não." (Eugênio).

Este pequeno recorte da fala de Eugênio se deu no início da sessão em que ele trouxe, pela primeira vez, contos e poemas de sua autoria. A sessão ocorreu antes de tocarmos no assunto religião e, na verdade, abriu caminho para este e outros temas, sobre os quais já discorremos 
no tópico anterior. Entre eles, a intensa raiva dirigida ao pai, que estava recalcada, e as lembranças de sedução e proximidade excessiva com a mãe. Somente nesse momento vamos começar a abordar a questão da escrita de Eugênio, porque até agora nos interessava discutir a ideia de destino, e as identificações que constituem o superego, que, por sua vez, marcam também um período da análise em que estas eram as questões emergentes. Outro motivo de introduzirmos agora o tema da escrita na análise é que foi a partir destes contos que encontramos uma possibilidade para trabalhar conteúdos que, em quantidade e qualidade, eram traumatizantes. Tal escrita reordenou o curso da análise e o equilíbrio de forças presentes no superego do paciente, ampliando, em consequência, o espaço de criação de novos modelos identificatórios.

Sabemos que a teoria dos sonhos, formulada por Freud em 1900(/1990b), apresenta os sonhos como um modelo de funcionamento do aparelho psíquico e como fenômeno resultante desse psiquismo que busca a realização de desejos. O sonho poderia ser descrito como substituto de uma cena infantil, que foi modificada para transportar-se para uma experiência recente. Se a cena infantil é incapaz de ser revivida e tem de aparecer deformada como um produto do inconsciente, ela precisa passar por processos que tornem possível a sua emersão na consciência. Então, a formação de um sonho consiste num trabalho. Encontramos a seguinte definição sobre o trabalho do sonho: "Conjunto das operações que transformam os materiais do sonho (estímulos corporais, restos diurnos, pensamentos do sonho) num produto: o sonho manifesto. A deformação é o efeito deste trabalho" (Laplanche \& Pontalis, 1992, p. 511). As operações que transformam a matéria-prima em produto são os mecanismos de condensação e deslocamento, descritos por Freud na Carta 52 (Freud, 1896/1990). São estes que realizam o trabalho, influenciados pela instância crítica.

Outra modalidade de sonhos é descrita a partir das neuroses traumáticas, que ocupam a atenção de Freud no texto Além do Princípio do Prazer (Freud, 1920/1990). Os sonhos 
traumáticos estão numa categoria diferente da teoria dos sonhos de realização de desejos. Levariam o sujeito de volta à situação de um acidente ou da cena causadora do trauma, fazendo-o despertar do sonho, sobressaltado, com um novo susto, como a cena original do trauma deve ter provocado. O fator surpresa é uma das condições para que um evento torne-se traumático, pois uma cena que acontece ao acaso não dá tempo para que a ansiedade seja disparada como sinal de alerta e o psiquismo seja preparado para o evento perigoso que possa estar por vir. Às vezes, os sonhos traumáticos apresentam-se com poucas deformações em relação ao episódio causador do trauma. Ainda assim, passam por certo tipo de trabalho, provavelmente menor do que os sonhos de realização de desejos. Mesmo os sonhos traumáticos e os de punição representam uma satisfação de desejo, ainda que seja desejo de uma tentativa de elaboração do trauma e desejo de sofrimento pelas tendências masoquistas do ego, respectivamente (Freud, 1920/1990).

Essa referência à teoria dos sonhos é para grifar a questão dos sonhos traumáticos. O paciente nunca havia falado sobre qualquer tipo de sonho, mas traz contos para ler na análise. Nesse primeiro contato com o material do paciente, os contos recebem o nome de contos traumáticos. A primeira ideia que ocorreu à analista foi trabalhar os textos a partir do modelo do capítulo VII de A Interpretação dos Sonhos (Freud, 1900/1990b), inspirada pelo comentário do próprio paciente de que o primeiro conto que iria ler tinha sido escrito na manhã seguinte ao acidente do pai. Trabalhar estes primeiros contos como um sonho traumático surtiu efeito, pois o paciente passou a falar sobre os elementos dos contos isoladamente. Posteriormente, começou a lembrar cenas de intensidade suficiente para serem traumáticas, e pensar sobre as personagens que compunham sua história começando a conectar-se com afetos relacionados a elas. Aos poucos, na medida em que foi falando e descolando-se das cenas, voltou a ter uma produção escrita. Por vezes, após as sessões, como se estas tivessem ficado presentes em seu psiquismo na forma de restos diurnos, que tomavam 
força na medida em que se ligavam aos estímulos internos presentes no seu inconsciente - mas esse já é um segundo tempo da literatura de Eugênio. Por enquanto, nos ocuparemos dos contos traumáticos.

As questões teóricas que começaram a rondar os pensamentos da analista referiam-se ao estatuto desses textos e ao manejo técnico adequado, pois anunciavam um elemento novo na condução desse tratamento. Eram textos catárticos ou eram sublimatórios? O que estava acontecendo com o superego, que começava a ceder o lugar da severidade para um espaço de benevolência e cuidado? Eram textos que podiam ser pensados como os sonhos traumáticos, como um recurso utilizado pelo paciente na tentativa de resolver os seus conflitos, ou uma forma de resistência ao tratamento?

Freud, em 1908(/1990b), usa o escritor criativo para tratar do tema da criatividade e das fantasias nas crianças e nos adultos, e este parece ser um dos únicos momentos em que ele pensa, ainda que brevemente, a questão do criar. Traça semelhanças entre o brincar infantil e o escritor criativo, no sentido de que ambos fazem um grande investimento afetivo na sua produção, criam um mundo próprio, mas conseguem manter com clareza os limites entre fantasia e realidade. Diferentemente do neurótico, que vai fazer uma regressão da libido até a fantasia, e demonstra dificuldade em separar o seu mundo fantasioso da realidade. O devaneio adulto, no qual ocorre uma fantasia mas o sujeito sabe que é um devaneio, é diferenciado da fantasia do neurótico, que nega a realidade. Porém os dois são marcados pela vergonha e o pudor, por conteúdos proibidos ou infantis, numa demonstração, segundo a tese freudiana, de que somente os insatisfeitos teriam necessidade de fantasiar. Nesse sentido, o sonho também é um equivalente da fantasia, pois o que Freud afirma é que ambos são formas de realização de desejos. Só que o sonho ocorre enquanto dormimos.

Façamos um resumo das etapas da análise de Eugênio em três tempos: o primeiro, no qual ele passa oito meses narrando, a conta-gotas, situações traumáticas específicas, de que 
tratamos no capítulo um; o segundo momento analítico, no qual traz os primeiros contos para análise - contos que ele já tinha escrito antes de iniciar a análise -, marcando a primeira virada do tratamento; e o terceiro tempo, no qual ele passa a escrever novos contos e ocorrem fatos que marcam a segunda virada do tratamento. Este resumo é para delimitar que iremos tratar a produção literária de Eugênio em dois momentos distintos. Primeiramente, nos ocupamos dos primeiros contos, que estavam engavetados até o oitavo mês da análise, e que nomeamos de contos traumáticos. Qual o estatuto dos contos traumáticos?

Em abril de 2008, esteve na USP a psicanalista e pesquisadora Sophie de MijollaMellor. Na conferência proferida no colóquio Razão, Loucura e Criação, ela afirma que a ideia comum de que a escrita ou a expressão artística sejam, para os criadores, meios de canalizar e mesmo exorcizar as pulsões que de outro modo os conduziriam ao acting-out é uma concepção inapropriada da sublimação. Isso porque esta psicanalista entende a sublimação como uma operação que tem por fim a satisfação pulsional e que, nisso, se aproxima de um funcionamento perverso sem, no entanto, se confundir com ele. A partir de três exemplos - Sade, Agatha Christie e Nabokov - ela trabalha a tese de que a criação não é um escudo contra a loucura, e, sim, sua caixa de ressonância. Isso maximizaria a loucura a ponto de seduzir o público, mas, simultaneamente, derivando em direção a um encontro que se dá sob o signo de Eros, da junção e do prazer, graças à sublimação. A definição metapsicológica de Mijolla para sublimação (2005) é que o eu força o supereu a amá-lo, renunciando à forma criticada por esse último, e edificando por meio de seu trabalho uma forma nova de eu sobre o modelo preconizado pelo ideal.

Carvalho (1997) ocupa-se dos limites da escrita como sublimação, partindo da inquietação sobre a produção literária como função terapêutica. Ela, assim como Mijolla, escolhe escritores conhecidos para sustentar suas ideias, porém escritores suicidas. O título do artigo Escrita: remédio ou veneno? (Carvalho, 1997) dá conta da ideia de que escrita não é 
terapia e que os efeitos da criação literária podem ser mais benéficos para o leitor do que para o escritor, pela distância que o leitor consegue resguardar dos conflitos. A conclusão é que "a escrita como remédio desnuda-se em seu avesso, veneno que pode matar" (p.86), ou seja, que não seria recomendado a ninguém escrever para se tratar.

Esse debate nos confirma que seguimos um caminho importante que foi o de não nos encantar com os contos de Eugênio e tomá-los de primeira como um movimento sublimatório, derivado de uma satisfação pulsional. Concordamos com a ideia de Mijolla (2008) de que nem toda produção literária é sublimação e também estamos de acordo com a proposta de Carvalho, de que escrever não é remédio, não pode estar no lugar da função terapêutica. Isso nos permite afirmar a ideia de contos traumáticos, no sentido de que os contos iniciais de Eugênio não eram resultantes de um movimento sublimatório, eram produções que mostravam o excesso de sentimento do paciente nas cenas traumáticas vivenciadas. E de que sua escrita foi um recurso utilizado inicialmente para tentar dar conta de significar algo que estava em excesso.

Os contos traumáticos de Eugênio eram como os sonhos traumáticos. Mantinham um grau de aderência ao real, mas tinham uma dose de trabalho psíquico, portanto, não eram simplesmente mera descarga pulsional, e sim denunciavam um desejo, mesmo que fosse o desejo de elaboração de um trauma como vimos na definição freudiana de 1921(/1990). O risco de a escrita substituir o tratamento, levantado de forma pertinente por Carvalho (1997), não se deu no caso deste analisando. Eugênio não usou os contos no lugar de um tratamento psíquico: ao contrário, mesmo sendo contos que por um tempo serviram para estancar a enxurrada pulsional que acometia o ego, devido ao excesso traumático, estes foram levados ao tratamento analítico como outro recurso para ajudá-lo a sair de seus conflitos, não substituindo um recurso pelo outro. Acreditamos que esse seja o principal valor desta pesquisa, poder investigar teoricamente questões importantes da metapsicologia a partir da 
experiência de condução de um caso clínico. O que resguarda alguma diferença em relação a teorizar a literatura de autores consagrados.

Definido o estatuto do primeiro tempo de produção do paciente, resta a questão técnica - de como dar conta da inclusão deste material na análise. Ferenczi, em 22 de março de 1932 (/1997a), escreve sobre os sonhos traumáticos de uma paciente para falar do retorno do trauma no sintoma, nos sonhos e na catarse. Este nos dá um caminho: o de que a cura dos fragmentos traumáticos não está em reconstituir o trauma na íntegra, mas em aceitar uma falta. Desse modo, podemos entender que a catarse, para o autor, não é uma mera descarga de catexias represadas, mas uma preparação para a produção de sentido, na medida em que pressupõe reconhecer uma falta e, consequentemente, passar pelo processo de luto referente a essa falta.

As ideias de Ferenczi sobre técnica psicanalítica produzem certa perturbação na maneira clássica de analisar, mas, se trabalhadas dentro de um corpo teórico, podem ampliar a possibilidade de análise de alguns pacientes. Esse autor, em El Empantanamiento en la Catarsis y su Remedio, 1932(/1997b), comenta que o trabalho de tentar produzir sentido quando existe um sonho traumático exige do analista paciência e sacrifícios muito grandes, além de empatia, renúncia de toda autoridade velada e à pretensão de ensinar ou ajudar o paciente. Estaria nos dizendo que a catarse em si produz sentido? Ou que é o lugar de testemunho ocupado pelo analista que oferece condições para esse trabalho? Não é por mera coincidência que terminamos o capítulo anterior com a indagação de Kristeva (2002) sobre como um obsessivo, com segredos inconfessáveis, faria um tratamento que pressupõe justamente colocar suas misérias humanas em palavras.

Se por um lado os contos de Eugênio encerram em si a fala, podendo ser um impasse à continuidade do tratamento, já que a análise é um método que necessariamente passa pela palavra, por outro ele pode ser um recurso clínico. Depende da capacidade narcísica do 
analista de se despir de seus escudos técnicos para escutar as enunciações do analisando. Aqui, nesse caso, era perceptível o desesperado pedido de ajuda, endereçado à figura da analista, contido nos ecos de cada palavra durante a leitura dos contos na sessão.

Ferenczi (1930/1992) é enfático ao dizer que não devemos abandonar tão prontamente os métodos antigos e fundadores da psicanálise em detrimento das novas técnicas. Defende a neocatarse como uma forma de afrouxar as resistências, a fim de remeter o paciente ao processo de rememoração associativa. Na época em que Eugênio trouxe os contos para a sessão, ainda não tínhamos presente essa ideia de neocatarse como uma etapa preliminar à produção de sentidos. A experiência foi nos mostrando a importância da atitude da analista de receber os contos e deixar o paciente livre para decidir o que fazer com o material. A abertura à leitura dos contos em sessão, inclusive, se tornou uma forma de estabelecer empatia com ele, sem abrir mão da neutralidade necessária para criar as condições de um espaço para a escuta analítica. Essa atitude possibilitou ao paciente aproximar-se das cenas traumáticas, de uma forma não tão direta, trabalhando os contos como restos diurnos, e passando destes para as marcas mnêmicas que se encontravam no inconsciente e careciam de um trabalho de ressignificação.

Encontramos no Dicionário do Pensamento de Ferenczi (Kahtuni \& Sanches, 2009) um verbete chamado técnica de relaxamento ou relaxação (neocatarse), no qual o autor propõe que o relaxamento promova a regressão até certos pontos em que pode ocorrer uma erupção de energias estancadas sem que isso vá contra a análise da transferência e das resistências. Ao contrário, seria uma forma de lidar com a dissociação de certos conteúdos e afetos, possibilitando integrar na personalidade o que era tido pelo paciente como vergonhoso. Essa técnica do relaxamento, diferentemente da técnica ativa, exige um posicionamento do analista verdadeiramente mais tolerante, compreensível e protetor, permitindo ao paciente que padece de culpabilidade - pela identificação com o agressor -, lidar com os conteúdos 
rechaçados da mente que o faziam ficar nesse lugar de identificação estática com o outro. Lembremos que, para Freud, não bastava recordar o trauma, mas substituí-lo por uma ação na transferência. Nesse sentido escreve Ferenczi (1931/1992)

Não é raro os pacientes nos trazerem, muitas vezes em meio às suas associações, pequenas histórias compostas por eles, até mesmo poemas ou rimas forçadas, alguns me pedem um lápis para me presentear com um desenho ou um retrato, em geral muito primitivo. Naturalmente, deixo-os fazer tudo isso e aceito essas pequenas doações para me servirem de ponto de partida para outras formações fantasísticas que serão mais tarde submetidas à análise. E isso, por si só, não evoca já um fragmento de análise de criança? (p.75).

A ideia de definir o primeiro momento da produção literária do paciente como contos traumáticos encontra ancoragem na teoria freudiana do sonho traumático, na ideia de neocatarse ferencziana e na função de testemunho como tentativa de representação do trauma, trabalhado por Seligmann-Silva (2000). Este último autor ocupa-se do tema dos limites das representações diante de catástrofes e questiona, utilizando-se das ideias de Friedlander \& Lyotard, como é possível representar algo que vai além da nossa capacidade de imaginar e representar. Ele busca na filosofia argumentos para essa reflexão sobre a literatura da experiência traumática, e encontra as teses de que essa tentativa de representar o real não se dá sem tensões. Nela o objeto escapa à representação justamente devido ao seu "excesso", que não pode ser tradu zido em frases.

Seligmann-Silva (2000) propõe a ideia de testemunho, a partir da literatura produzida por pessoas que viveram o Holocausto. A sua tese é de que esse tipo de arte, de pessoas que vivenciaram catástrofes, é um evento do que não pode ser representado e que deve ser testemunhado - porém, como uma tentativa de dar conta do excesso que transborda a capacidade de pensar, permitindo ao sujeito um tipo de representação. O autor apresenta o 
conceito de Lyotard, de que o testemunho é, em geral, fruto de uma contemplação: a testemunha é sempre testemunha ocular. Testemunha-se sempre um evento. A palavra alemã para evento é justamente Ereignis (que vem de ir-ougen, sendo que ouga quer dizer olho), que, etimologicamente, significa "pôr diante dos olhos, mostrar" (Seligmann-Silva, 2000, p.82-3. Diz-nos o autor que, para Lyotard, o testemunho de um agora se conecta com a categoria de um sublime, elemento também filosófico, porque gera um prazer eminentemente negativo, já que o sublime produziria uma suspensão, um desativamento da consciência.

A ideia inicial de trauma em Freud, de que todas as histéricas padeciam de um abuso, foi substituída na Carta 69 (1897/1990), e no rascunho M (1897/1990), pela ideia de um fantasma. Ou seja, de fantasias edípicas que acompanhavam o Complexo de Édipo e que se tornam traumáticas a posteriori. Mesmo abandonando a teoria inicial de trauma sustentada na ideia de um abuso real, a tese de excesso pulsional permanece, em Freud, como no sublime, e tem a ver com um excesso de catexias incapaz de ser metabolizado no interior do psiquismo, tornando-se traumático aprè coup. Esse excesso é que permite o desenvolvimento da teoria dos sonhos traumáticos - nesse caso clínico, os contos traumáticos, por intermédio dos quais Eugênio voltava às cenas traumáticas. Nesse sentido é que a leitura dos contos traumáticos na sessão analítica entra como um pedido de ajuda - "sendo o terapeuta destinatário e testemunha que permitiria a produção de sentido para o seu sofrimento”. (Kupermann, 2008, p.115).

Encontramo-nos em um momento da análise em que a condução do tratamento precisou de muita prudência da analista: em função do elemento novo que os contos representaram no setting analítico, e conforme o caminho técnico adotado, o paciente podia sentir-se novamente abandonado, como aconteceu em relação às figuras parentais, e interromper as sessões. Kupermann (2008) realiza um trabalho de cotejamento da evolução da técnica freudiana e ferencziana, destacando os recursos que, clinicamente, atendem às 
necessidades de pacientes difíceis. A presença sensível do analista é tida como um ingrediente necessário a ser acrescentado ao movimento catártico do paciente para efetivar a experiência de testemunho na análise, criando neste a convicção necessária para o movimento psíquico. O autor havia proposto em Ousar rir: humor, criação e psicanálise (Kupermann, 2003), a partir dos aportes ferenczianos, um manejo clínico que permitisse trabalhar com esses pacientes, desenvolvendo concepções clínicas de análise pelo jogo, que dessem conta de promover o encontro afetivo entre a dupla analítica para alcançar o movimento psíquico do paciente. Reafirma que "numa psicanálise de "crianças" desse tipo não basta pretender falar "da" criança, tampouco interpretá-la; é preciso poder falar "com” a criança, de um modo que faça sentido para ela”. (Kupermann, 2008, p. 121).

Algumas das questões teóricas que levantamos no início desse capítulo puderam ser contempladas nesse tópico. É certo que, no início do tratamento de Eugênio, os contos tinham o estatuto de contos traumáticos que promoviam uma catarse ao serem endereçados à analista. A diferença entre o conceito de catarse em Freud e Ferenczi reside justamente no fato de que, para o segundo autor, a catarse é endereçada a alguém; esse movimento do analista de testemunhar um evento é o que prepara para a produção de sentido, pois acrescenta algo ao movimento catártico. Escutar a leitura dos contos de Eugênio, sem interpretar essa produção partindo do pressuposto de que fossem textos com estatuto de produção sublimatória, e sim tomando os contos para serem trabalhados a partir do modelo da interpretação dos sonhos, produziu uma mudança no tratamento.

$\mathrm{Na}$ medida em que o paciente lia os contos, a analista posicionava-se silenciosamente a escutar, e, posteriormente, o convidava para conversarem juntos sobre os escritos, foi se estabelecendo uma relação de circulação afetiva entre a dupla. O paciente pôde adquirir confiança na analista, de que esta estava a lhe escutar sem repetir o excesso narcisista que o deixou psiquicamente desamparado na infância e adolescência. $O$ vínculo afetivo e de 
confiança construído entre essa dupla analítica fez com que a análise inaugurasse no psiquismo do paciente outro modelo de funcionamento, promovendo um movimento pulsional diferente, permitindo que os excessos começassem a ser ligados, propiciando uma elasticidade psíquica. Outro tipo de identificação começou a se esboçar. O superego, que escrevera os primeiros contos, começava a ceder em sua força mortífera para uma identificação de confiança com a analista.

O segundo movimento dele consistiu em começar a falar de outros contos, escritos a partir das sessões de análise. Esse momento é mais próximo de uma narrativa tal qual a de um paciente que fala sobre os sonhos em sessão. Seguia levando os contos à analista, porém não precisava mais ler. Deitava-se no divã e contava o que havia escrito e o que pretendia escrever. Esse movimento indicou que o paciente já estava um pouco descolado dos fatos concretos, delineando a direção ao mundo das fantasias, resguardada a distância necessária da realidade, e mostrando uma produção do inconsciente como um possível retorno do recalcado - e não mais contos traumáticos que davam conta de um excesso real.

Outro estatuto de escrita surgiu mais próximo do movimento de um escritor criativo, que consegue usufruir do prazer de criar. Dar os contos à analista, além de significar que ele confiava seus conteúdos a esta, certamente era uma atitude de tentar conquistá-la e ver na sua reação o próprio valor. Este ele ainda não sabia qual era, já que o pai sempre depreciava sua escrita. Muito perspicazmente, percebia que a analista gostava de receber seus contos, e que ele produzia um prazer no outro com sua produção. Mas também interpretamos como um pedido de Eugênio para que a analista guardasse seus conteúdos até que ele pudesse escolher o destino que daria à sua produção. Nitidamente o superego começava a ser menos rígido e as catexias aos poucos se movimentavam no psiquismo, propiciando condições para o movimento de criar. Outra modalidade de funcionamento emergia no analisando. 
Fédida (1991) trabalha a ideia de como fazer a passagem dos sonhos à linguagem, e o faz dizendo que a pessoa só se torna analista quando este se coloca a justa distância que permita ao analisando falar. Cabe ao analista, também, questionar, de forma que o paciente possa escutar-se, propiciando um movimento de saltar ao desconhecido a partir da relação assimétrica que se estabelece. Para o autor, a indagação do analista não é necessariamente falada, pode ser a capacidade de se dispor ao silêncio da escuta, que é uma forma de questionamento singular, pois desperta a linguagem do paciente.

Entendemos que Fédida (1991) esteja falando da linguagem não como a dos meios de comunicação social, mas das enunciações e endereçamentos que as falas e atitudes dos pacientes nos transmitem e, consequentemente, como nós, analistas, respondemos a estas. Seguindo o raciocínio do autor, a questão complicadora no tratamento de Eugênio era a de como a analista poderia ocupar ao mesmo tempo o lugar de testemunha, destinatária de uma série de questões, com quem o paciente tinha uma relação de empatia, e a de analista propriamente dita, no sentido de introduzir a diferença, fazê-lo descolar do real e escutar-se nas memórias inconscientes. O movimento de deitar-se no divã e contar sobre os contos, em vez de lê-los, foi o marco dessas mudanças no funcionamento psíquico do paciente e no tratamento e manejo clínico por parte da analista. Uma atitude analítica mais rigorosa, no sentido de rigor técnico e não de rigidez emocional, foi adotada. Assim, a analista falava menos, interpretava algumas resistências, mas, também, permitia a existência de momentos de construção com o paciente de recursos que lhe faltavam - ingredientes dosados conforme a percepção de cada momento. 


\section{2 - Ideal do ego, superego benevolente e a sublimação}

"Como é que eu vou aceitar que o meu primo matou a minha tia, que é tia dele, é uma loucura total. Eu sempre soube que a família do meu pai é louca, mas isso é demais. E o Otávio é que nem eu. Nos últimos cinco anos ele foi o meu melhor amigo, a gente estava sempre junto, ele era o meu ídolo... agora eu já não sei mais nada. Tu entendes que se isso for verdade eи vou ter que repensar tudo. Eu vou ter que repensar tudo, quem eu sou, as pessoas com que eu me dou, minhas amizades, os conceitos, valores de vida, tudo. Meu mundo vai cair. Se isso for verdade eu vou desabar.” (Eugênio).

Voltemos à questão que permanece em aberto tratada no ponto 2.2 , a do ideal do ego ser uma faceta do superego ou ser outra instância, distinta. Se o tema das identificações nos auxilia na compreensão de como se constitui o superego, é possível que encontremos uma saída, a partir também das identificações, para entender quem é o ideal do ego e as relações desse com o superego. O que abriria caminho para, futuramente, aprofundarmos as relações entre o ideal do ego e a sublimação. Questionar a sublimação a partir da instância superegóica pode ser uma forma de adentrar no estudo da sublimação, necessário para um analista clínico. Mas isso requer uma outra pesquisa. Por hora, o desenvolvimento do nosso raciocínio é na direção de compreender a relação entre o superego e o ideal do ego.

No mesmo texto a que já nos referimos, de 1921(/1990), Freud escreve um capítulo sobre os movimentos que seriam responsáveis pelo fenômeno da idealização. Ele dá o exemplo do que ocorre nos apaixonamentos, quando o objeto não seria colocado no lugar do ego, mas introjetado no lugar do ideal do ego. Nesse caso, o ego do sujeito adotaria posições humildes, sujeitar-se-ia a limites narcísicos e ficaria consequentemente empobrecido, deslocando grandes quantidades de catexia para o objeto. Nesse percurso, Freud levanta a 
pertinente questão sobre a possibilidade de haver um tipo de identificação em que o objeto amoroso não é abandonado, ou seja, uma identificação na qual o investimento libidinal pudesse mudar seu objetivo em relação ao objeto, sem abandoná-lo. Estaria, nesse caso, começando o autor a esboçar pensamentos que levam ao caminho de um quarto tipo de identificação?

Em outro exemplo de diferença entre o ego e o ideal do ego, um objeto é posto no lugar do ideal de ego e surge a identificação com o líder de um determinado grupo. Há uma afirmação de que cada indivíduo, por pertencer a numerosos grupos e partilhar de muitas mentes grupais, acha-se ligado por vínculos de identificação em muitos sentidos e a partir daí consegue fazer aquisições individuais. Diz Freud (1921/1990): "estamos cientes de que aquilo com que pudemos contribuir para a explicação da estrutura libidinal dos grupos reconduz à distinção entre o ego e o ideal do ego e à dupla espécie de vínculo que isso possibilita, ou seja, a identificação e a colocação do objeto no lugar do ideal do ego". (p.164).

Então, no capítulo intitulado Gradação Diferenciadora no Ego (1921/1990), é retomada a distinção entre o ego e o ideal do ego, para tratar da diferença do movimento de identificação e do movimento de idealização, enquanto que, em 1923(/1990),, é trabalhada outra gradação no ego, distinta, que é entre ego e superego. Já sabemos que na primeira relação, entre ego e ideal do ego, pode ocorrer de se dissolver temporariamente a gradação, levando o ego e o ideal de ego a coincidirem. Essa situação provoca uma sensação de triunfo resultante de uma hipercatexia no ego, pois o que era o ideal do ego está agora coincidindo com o ego. Volta-se temporariamente a experimentar um momento de ego ideal, o que se manifesta, por exemplo, na mania. Uma vez que falamos da relação do ego com o ideal do ego com base na ideia de que superego e ideal de ego são duas instâncias distintas, ambas gradações diferentes do ego, qual seria, afinal, a relação do ideal do ego com o superego? 
Antes de seguirmos no debate proposto, é necessário pinçar mais duas questões na obra do Freud. A primeira é sobre a metapsicologia do superego, que aparece no texto do Humor (1927/1990), onde se propõe uma versão benevolente dessa instância. De pronto, é considerada a hipótese que já havia sido trabalhada em Os chistes e sua relação com o inconsciente (1905/1990b), de uma questão econômica, em que o humor é um recurso para poupar os afetos que seriam despendidos em uma dada situação. Em seguida, definem-se as características do humor, como detentor de algo de liberador, assim como os chistes e o cômico. Mas também como possuidor de uma grandeza que não é encontrada nas outras duas maneiras de obter prazer intelectual. O prazer do humor reside num triunfo narcísico, no qual o ego fica inabalável e prevalece o princípio do prazer - arma prefeita contra a crueldade das circunstâncias reais.

A explicação freudiana de que o humorista adquiriu uma superioridade por assumir o papel do adulto, tratando as outras pessoas como crianças, é possível se houver uma identificação até certo ponto com o pai. Essa atitude seria uma forma de evitar o sofrimento sem ter que padecer de uma neurose ou até de patologias mais graves. Se no núcleo do ego há um superego cruel, a dinâmica humorística, segundo Freud (1927/1990), se dá de forma a que grandes quantidades de catexias sejam retiradas do ego e transportadas para o superego. Diante do superego inflado, o ego pareceria, então, minúsculo - como o de uma criança - e todos os seus interesses passariam a ser triviais. O superego tentaria, por meio do humor, consolar o ego e protegê-lo do sofrimento.

Parece-nos que ao terminar o texto de 1927(/1990),,, dizendo que o superego benevolente em nada contradiz sua origem no agente paterno, mas é resultante de uma identificação até certo ponto com o pai, Freud tenha querido afirmar que esta poderia ser a mesma identificação esboçada no capítulo oito e onze do texto de 1921(/1990),.. O resultado seria a identificação com o pai no que ele ocupa de posição protetora, pois, ao interditar o 
incesto, promove uma ferida narcísica, mas, ao mesmo tempo, protege o ego da criança de uma fratura narcísica no caso da não percepção de sua insuficiência infantil ou ainda de uma consumação incestuosa abusiva. Uma identificação até certo ponto com o pai ficaria albergada no superego, sem precisar renunciar totalmente ao amor pelo objeto, promovendo um vínculo com este por meio da identificação com o agente paterno pelo compartilhamento de um ideal protetor. Esse é um pensamento que poderia ser um avanço na compreensão do superego, no sentido de resgatar a dupla face dessa instância, que pode ser cruel mas também benevolente e amável com o ego do sujeito, tornando-se uma instância organizadora e protetora do psiquismo.

Kupermann (2003) trabalha a ideia do texto do humor como um novo paradigma para se pensar a sublimação. O superego esteta, como é nomeado pelo autor, é remetido às intrincadas relações com o narcisismo e com o ideal do ego. Este último, como outra instância diferente e separada do superego, permitiria pensar as relações entre o superego, o ideal do ego e a sublimação, a partir das problemáticas do narcisismo, das identificações, da dessexualização, do trabalho de luto e do desamparo. Essa dinâmica é possível a partir da proposta do autor de que existe uma identificação sublimatória que teria a característica de ser parcial e referente ao Édipo, dando conta da proposição freudiana de "identificar-se até certo ponto com o pai."

A segunda questão que precisamos incluir e clarear, agora que estamos nos ocupamos de quem é o ideal do ego, é outra distinção, a de ideal do ego da noção de ego ideal. No texto do Narcisismo (1914/1990), Freud nomeia ego ideal e ideal do ego, sem deixar clara a diferença entre essas duas instâncias. O que é possível apreender nesse texto é que o ego ideal é o alvo do amor de si mesmo, que se acha possuído de toda perfeição de valor; quando surge a interferência de terceiros e o próprio julgamento crítico do sujeito, essa suposta perfeição não consegue manter-se e o sujeito projeta diante de si o narcisismo perdido da infância como 
sendo seu ideal. Laplanche \& Pontalis (1992) definem o ego ideal como um ideal narcísico de onipotência forjado a partir do modelo do narcisismo infantil. Encontramos no trabalho desses autores as indicações de que Lagache define o ego ideal como sendo resultante da identificação primária com a mãe, ao passo que Lacan trabalha o ego ideal como uma formação narcísica que tem sua origem na fase do espelho e pertence ao registro do imaginário.

Castiel (2007) retoma essa distinção entre ego ideal e ideal do ego, afirmando que, mesmo não sendo clara a diferenciação no corpo do texto freudiano, é possível ver que os ideais são tratados dentro de duas perspectivas distintas: o ego ideal diz respeito aos ideais da criança vividos pelo ego real, no qual a criança é seu próprio ideal, enquanto que, na segunda perspectiva, o ideal é o substituto do narcisismo perdido, os ideais são as metas a serem alcançadas. A autora também retoma Lacan (1954) para marcar a ideia de que o ideal do ego, diferentemente do ego ideal, levaria em conta a norma exterior, a lei, e esta requer uma modalidade de organização discursiva distinta da do ego ideal. Essa observação feita por Lacan é preciosa, na medida em que ressalta que o sujeito só projeta o narcisismo diante de si como algo a ser buscado na forma de um ideal por existirem as interferências de terceiros, ou seja, o ideal do ego é permeado pela castração.

Discernido o que é ego ideal do que é ideal do ego, seguimos no caminho de firmar o ideal do ego como instância distinta do superego, porém estreitamente ligado a este. Chasseguet-Smirgel (1992) é outra autora que contribui na defesa dessa tese, de que o ideal do ego é uma instância própria e deriva-se da insuficiência primária infantil: na impossibilidade de consumar o incesto com a mãe e evitando confrontar o rival, o menino sai à procura do que faz do pai o objeto da mãe, sendo levado, então, a projetar, diante de si, o desejo de assemelhar-se ao pai, o qual se tornará o seu ideal do ego. Ela confirma a existência de uma diferença entre o ideal do ego, herdeiro do narcisismo primário, e o superego, herdeiro 
do Complexo de Édipo. O primeiro constituiria uma tentativa de recuperação da onipotência perdida, a ilusão, enquanto o segundo, proveniente do complexo de castração, busca promover a realidade. O ideal do ego leva a esperança de fusão com a mãe, o superego separa a criança da mãe.

Para a autora, extinguir o ideal do ego, como se tivesse sido possível renunciar a toda a ilusão edipiana em relação ao objeto, acabando com a ferida narcísica, ou, o contrário, se a ferida ficasse sempre aberta, poderia aumentar desmesuradamente o ideal por uma nova estirpação do narcisismo do ego em seu proveito. Compartilhamos com Chasseguet-Smirgel (1992) que isso não acontece nem para um lado, nem para outro, por três motivos: o superego, como herdeiro do Complexo de Édipo, é uma instância protetora do narcisismo da criança edipiana - atribuindo a uma proibição o que é o fato de sua miséria sexual intrínseca, o superego age como um ditame sobre a ferida narcísica, impedindo uma hemorragia libidinal do ego em direção ao seu ideal; o emprego, particularmente importante, no período pósedipiano, das atividades sublimatórias; e a possibilidade de procurar a fusão perdida no amor com um objeto que não é mais o objeto edipiano.

Chasseguet-Smirgel (1992) alerta para o movimento da literatura psicanalítica de acentuar a severidade universal do superego, se omitindo de distinguir os diversos tipos de fatores atribuídos aos herdeiros do Complexo de Édipo. Ela compartilha a ideia, com Joseph Sandler, que escreve em 1959 sobre o superego, de que em certas situações o ego pode desdenhar os preceitos do superego para ganhar uma contribuição narcísica. É o que pode ser observado nos fenômenos de grupo, quando um superego próprio pode ser substituído por ideais coletivos, mesmo que esses não coincidam com os ideais singulares. Então, com essa tese freudiana de que os ideais do grupo, ao permitirem uma gratificação direta dos desejos pulsionais possam provocar uma transformação de caráter ao ponto de o superego ser abandonado e permitir delitos hediondos, "penso que não basta dizer que o homicídio é então 
cometido em nome do superego e que assim se torna lícito; creio que ele se realiza antes de tudo em nome do ideal..." (Chasseguet-Smirgel, 1992, p.74).

Esse caso clínico nos impõe, a todo o momento, a necessidade de compreensão das intrincadas relações entre o ideal do ego e o superego. Até então, Eugênio nos apresentava, nas brigas com a namorada, na impotência sexual e na ideação suicida, a face superegóica que marca os efeitos da crueldade de um superego constituído pela identificação narcísica com o pai. Estamos partindo da premissa da existência de uma identificação entre os ideais de um sujeito com os ideais de outros, tal qual acontece nos fenômenos grupais. Quando o paciente percebe que a terceira geração da família é assolada pela compulsão à repetição catastrófica do mortífero superego, ele é tomado por um sentimento de desespero, porque confirma que sua identificação era também com os ideais de várias gerações, ideais, como já dissemos, de matar ou morrer. Se ele havia colocado no primo a função de ser seu líder, como se essa pudesse ser uma saída, e o ideal de ego do primo é também o de ser alguém se tornando um homicida, isso ganhou o significado, para ele, de que o destino funesto batia à sua porta.

A ideia de um superego benevolente, nesse caso, surge a partir do trabalho feito por meio dos contos que ele lia na análise, contos esses que, como falamos, foram trabalhados seguindo o modelo da interpretação dos sonhos. Quando Kristeva (2002) questiona as fixações do obsessivo, que o impediriam de falar numa análise, nos remete a uma inquietude que a analista tinha nos primórdios da análise de Eugênio - e que ele desfaz ao surpreendê-la com a leitura dos contos. Eugênio, como historiador, nos dá acesso a historiar a sua dor, possibilitando dar outro sentido à sua escrita e outro caminho para a sua vida.

Ao longo desse estudo sobre se o ideal do ego e o superego são instâncias distintas ou uma única com facetas diferentes, surgiu a possibilidade de reivindicar como original poder pensar a teoria a partir das inquietações que surgiram da condução de um caso clínico. Isso permitiria formular hipóteses teóricas que levem ao surgimento da teoria como um recurso no 
caminho para revigorar a prática clínica. Ao longo da história da psicanálise, desde 1927 e até 1992, quando Smirgel publica o livro do qual estamos nos ocupando, inúmeros autores estudaram, publicaram e posicionaram-se a favor ou contra essa tese de o superego e o ideal do ego constituírem instâncias psíquicas diferentes, sendo que Jones (1927) parece ter sido o primeiro a definir o ideal do ego como instância distinta do superego. Cada autor foi motivado por suas questões, suas filiações teóricas, suas experiências, enfim, sustentados por aportes diversos que explicavam esta ou aquela posição.

Devido à nossa tradição de estudos da obra freudiana, permanecemos muitos anos compartilhando da proposição final de 1932(/1990), de que o ideal do ego é uma das funções do superego. Porém, a identificação com a maneira investigativa, freudiana, de produzir a teoria psicanalítica com base na experiência clínica, nos autoriza, a partir do percurso com o paciente aqui descrito, e dos estudos realizados ao longo desse período de mestrado, a assumir, por ora, a tese de que o ideal do ego é, sim, uma instância distinta do superego. Se seguirmos a tradição psicanalítica, é necessário definir esse conceito dentro dos critérios tópico, econômico e dinâmico, para inscrevê-la como conceito metapsicológico. Simplificadamente, adotamos a proposta de o ideal do ego deixar de ser apenas uma faceta do superego quando entendemos que, topicamente, ele surge de uma gradação do ego, tendo suas raízes no narcisismo infantil e se reafirmando no Complexo de Édipo; dinamicamente ele prepara o caminho para o Complexo de Édipo, necessitando ser regulado para estar de acordo com as exigências da realidade exigidas pelo superego; e, economicamente, está profundamente intrincado no jogo de forças do superego e da sublimação, podendo ser responsável pela promoção de um movimento pulsional mais tanático ou outro funcionamento pulsional mais sublimatório, e, assim, passar a ter um lugar próprio na constituição psíquica.

Ao mesmo tempo em que passamos a entender o ideal do ego como instância independente do superego, nos propomos a recuperar o conceito de superego como tendo duas 
faces, mas duas faces próprias: um superego cruel e mortífero, resultante da identificação narcísica em consequência do Complexo de Édipo, e uma face benevolente, advinda de uma identificação até certo ponto com o pai - a identificação que permite o desvio dos objetivos sexuais e assim o sujeito poder identificar-se com o objeto sem precisar abandoná-lo. Podemos levantar uma hipótese para tentar responder à questão levantada no ponto 2.2 sobre como o superego e o ideal do ego se relacionam. Tal hipótese seria a de que as faces do superego podem se alternar em momentos distintos da vida, e que isso seria incitado pela relação com o ideal, já que uma das funções do superego é zelar pela satisfação do ideal do ego.

Na história clínica de Eugênio, podemos observar claramente essa dinâmica entre o ideal do ego e o superego. Percebe-se, desde o início, a partir das identificações primárias, a incorporação de um modelo cruel, que deixa marcas que se justapõem com as cenas de excesso da realidade e são reatualizadas e revigoradas nas identificações edípicas secundárias derivadas do Complexo de Édipo. Ao mesmo tempo em que o pai se mostrava o homicida que é, a mãe estimulava um potencial cruel e perverso, advogando em favor dos modelos perversos de organização. Tudo em seu psiquismo foi se organizando no registro das intensidades e não da capacidade de ligação amorosa, um ideal de ser homicida e de formar efetivamente um par romântico com a mãe constituiu um ideal do ego de que ser só é possível por meio do crime. O superego, produzido por identificações narcísicas com essas figuras parentais, desenvolveu e manifestou essencialmente sua face aniquiladora e mortífera, zelando, como preconiza uma de suas funções, pelo cumprimento desse ideal paterno que Eugênio projetou diante de si como seu projeto de ser como o pai - independentemente da qualidade que tenha esse ideal.

$\mathrm{Na}$ análise de Eugênio, os contos trabalhados dentro do modelo da interpretação dos sonhos surgiram como remédio. Ao confiar seus contos à analista, e permitir que ambos 
conversassem sobre as intensidades de sua vida, isso fez com que o espaço de análise inaugurasse uma condição de ligação dos excessos, a ponto de levar Eugênio ao encontro do seu desamparo sem precisar se matar. Uma relação de confiança inaugurada na análise, e confirmada no episódio em que Eugênio esboça uma transferência erótica, de que já falamos anteriormente - em um teste aos limites da analista, que age de forma não severa mas com um rigor técnico, pressupondo uma dose afetiva de perceber o outro e resguardar o espaço de análise do paciente que padece - exerceu um interdito, permitiu a Eugênio criar uma identificação com um modelo afetivo de alteridade e respeito. Uma identificação de confiança, como dissemos, instaura a abertura para criar outro ideal do ego, na medida em que algumas marcas de potencialidade estavam inscritas no seu psiquismo - "ser um grande homem ou um criminoso".

A reatualização do ideal homicida, por meio do episódio do romance familiar em que o primo-irmão do paciente mata a tia deles, faz Eugênio anunciar a necessidade de repensar seus ideais e valores de vida. Nesse momento, foi indispensável o arranjo para aumentar para quatro vezes semanais o número de sessões do paciente. Não havia mais possibilidade de manter alguma ilusão a respeito de seus pais e de sua família. Desabou do altar de suas ilusões, que ainda persistiam em suas identificações secundárias narcísicas com as figuras parentais, caindo num choro e num luto profundo e doloroso. A análise passou a ser o esteio desse paciente por um bom tempo, tempo suficiente para que elaborasse o luto pela perda desses antigos ideais cruéis de ser homicida e perverso.

Nesse período do tratamento, Eugênio demandou desesperadamente que a analista pudesse sustentar-se num lugar de rigor teórico, para assegurar-lhe a existência de outro modelo - o de alteridade presente sem que a confiança seja estilhaçada, como aconteceu também em relação ao primo. Faz-se necessário repetir, para grifar, que entendemos rigor teórico como uma postura do analista radicalmente diferente de uma posição de severidade ou 
rigidez afetiva. A neutralidade para escutar o sofrimento de Eugênio, ou de qualquer analisando, sem julgar seus ideais e suas vivências, pressupõe uma percepção de alteridade e de solidariedade ao sofrimento do outro. Posição do analista que não abarca um distanciamento afetivo, ao mesmo tempo em que exige perspicácia para silenciar quando possível e falar quando necessário, não incrementando com seus ideais o sofrimento do paciente.

Até que fosse desembaraçado o capítulo desse drama familiar do homicídio da tia, muitos convites e convocações foram feitas a Eugênio, pelo pai, avó, tias e o próprio primo, os quais, com sofrimento e alívio ao mesmo tempo, ele recusava, pois passou a se negar a tomar decisões sobre o destino deste episódio, rechaçando a proposta de ocupar o lugar que o pai o convocava. Houve certos momentos em que o paciente precisou literalmente escolher entre comparecer à análise e ir ao encontro da família, a qual se encontrava reunida, no mesmo horário, com o detetive que tratava dos assuntos de Otávio. Numa sessão específica, ele chega dizendo que tinha optado por estar ali e isso significava que ele estava escolhendo por ele, pela saúde emocional e física dele, pela sua vida, e que daquele dia em diante admitiria para si que nesse mundo ele só poderia contar com ele mesmo. E que, portanto, precisava da analista para criar valores e ideais singulares.

Não demorou muito tempo para que o paciente também rompesse seu namoro com Eduarda, que estava nessa linhagem de condensações cruéis familiares. Eugênio ocupa-se do que seriam seus desejos próprios, seu projeto de vida, e cria, numa oficina de literatura da qual fazia parte, uma personagem fictícia, que nos auxilia na continuidade do tratamento. Essa segunda fase de contos tratava dos desejos da personagem, de suas fantasias amorosas, de seus planos de vida, que consistiam em constituir uma família simples, ter uma profissão que pudesse lhe dar dinheiro suficiente para viver bem, e viver os pequenos dramas do cotidiano sem perder-se em atitudes cruéis. Esse seria o terceiro tempo da análise, e o segundo tempo da 
produção literária do paciente. Apesar de ele ainda utilizar-se da escrita, não trazia mais os contos para análise e simplesmente falava nas sessões sobre o que a personagem planejava para seu futuro, usando o espaço da análise para brincar com seus pensamentos e desejos, descobrindo-se como sujeito.

Não foi à toa que, mesmo passando todo esse tempo tratando de psicanálise, incluímos no início do trabalho o poema de Baudelaire. Poema que trata de um homem que era superior aos mortais, percebe as vantagens de perder suas insígnias e passar a ser um homem comum. O preço a ser pago para ser um grande homem nem sempre compensa, e, nesse caso clínico, especificamente, custaria a vida do analisando. Eugênio, um analisando muito inteligente, percebe a emboscada que significa, na sua tradição familiar, ser um grande homem, e, felizmente, traça um novo projeto de vida que é o de ser um homem simples, comum como todos os outros seres humanos.

Já falamos sobre a análise ter inaugurado um vínculo de confiança que propiciou uma identificação com a analista. O que podemos pensar é que a identificação com a analista se deu naquilo que esta representou de uma figura paterna cuidadora, proporcionando a Eugênio projetar diante de si esse ideal vivenciado na análise afetivamente, fruto de um investimento da analista e do analisando. Quando tratamos, no capítulo anterior, de que o pai de Eugênio aponta no filho dois potenciais, o de ser um grande homem ou um criminoso - pois vê em Eugênio recursos para ser alguém diferente dele, pai, capaz de resolver os problemas da família que o próprio não conseguia -, acreditamos que esses registros estavam inscritos no psiquismo e que esse vínculo de confiança possibilitou, a partir dessas inscrições, recuperar uma potencialidade que permitisse ao paciente constituir o ideal do ego amoroso.

Entendemos esse segundo tempo dos contos do paciente como outro estatuto de produção literária, no qual um movimento sublimatório acontece no seu psiquismo, incitado por esse amor transferencial que resgatou uma potencialidade do analisando de ter um ideal 
singular. Kupermann (2003), inspirado nas indicações freudianas acerca da identificação paterna no humor, traça uma hipótese metapsicológica para a identificação nos processos de criação sublimatória, considerando o que ele nomeia de "identificação sublimatória', como havíamos dito. A partir da leitura que faz da obra freudiana, este autor desenvolve a formulação de que o que está presente na melancolia é a mesma identificação narcísica presente no masoquismo feminino e moral - uma identificação narcísica com um objeto cuja perda é insuportável. A característica essencial dos quadros de masoquismos secundários, segundo o autor, deixariam de ser o prazer no sofrimento, e, compartilhando com a tese de Birman (1999), poderiam ser entendidos como tentativa de evitar o desamparo, na medida em que este é vivido como um terror pelo sujeito.

Kupermann (2003) adota a proposição lacaniana de que, para desfazer a confusão freudiana sobre ideal do ego e superego, o ideal do ego seria a instância que sublima, ao passo que o superego seria a instância que recalca. Assim, Kupermann (2003) desenvolve a tese de que na "identificação sublimatória" o que está em jogo é menos o superego mortífero, resultante da identificação narcísica, do que o ideal do ego, que incitaria a transgressão sublimatória. "Ao identificar-se sublimatoriamente com o pai, o sujeito passaria a ter acesso à função do ideal, podendo, a partir de então, erigir, no vazio existente, seu próprio ideal do ego; o que não deixa de ser uma transgressão aos olhos do superego ${ }^{1}$.” (p.212).

A proposta de uma "identificação sublimatória" confirma o trajeto que encontramos em Freud que aponta para um quarto tipo de identificação, uma identificação sobre a qual Freud se questiona em 1921(/1990), se poderia de fato existir, já que pressuporia não abandonar o objeto e sim mudar os objetivos da pulsão em relação ao objeto amoroso, podendo fazer uma sublimação dos desejos pulsionais, ou ainda, dito de outra maneira, identificando-se até certo ponto com o pai, como afirmado em 1927(/1990),. No caminho da

\footnotetext{
${ }^{1}$ Para acompanhar o desenvolvimento da identificação sublimatória em Kupermann ver capítulo III do livro Ousar rir: humor, criação e psicanálise.
} 
identificação sublimatória, descrita por Kupermann (2003), encontramos também o problema da escolha: o que faria o sujeito escolher por uma identificação narcísica ou sublimatória. $\mathrm{O}$ que, por ora, podemos resgatar, é que a identificação sublimatória, tal como proposta por Kupermann (2003), se dá da seguinte forma: após a dessexualização inerente do movimento identificatório, ocorre um trabalho de luto, possível por não ser uma identificação total com o agente paterno; esse trabalho de luto, quando completado, resulta numa sublimação, e, quando não completado, volta-se ao narcisismo e ao impedimento de um funcionamento sublimatório. Entendemos, então, que a identificação sublimatória consiste numa identificação edípica que permite a elaboração do luto quanto às idealizações, propiciando a criação de modelos de ideais mais singulares.

Não seria, então, a esse lugar que a análise de Eugênio havia chegado? Após um período do tratamento em que se ocupou basicamente do trabalho de elaboração do luto referente aos ideais que ele tinha, e que a produção literária nos mostrava uma nova vertente de funcionamento psíquico, ele construía, por meio da análise, ideais próprios, a partir de uma identificação até certo ponto com a analista, naquilo que ela representava como um agente paterno cuidador que investe amorosamente num filho. Ideais que passavam por aquisições simples, como a de qualquer homem comum, no sentido de não idealizado, e, principalmente, ideais possíveis de serem concretizados, permitindo a Eugênio ser um homem sem ser criminoso.

Passou a levar uma vida como qualquer outro rapaz no final da adolescência. Abandonou os ternos, começou usar camisetas, bermudas, deixou o cabelo crescer, fez uma pequena tatuagem, escrevia seus contos, paquerava, fazia investidas amorosas com sucesso e outras sem sucesso. Era capaz de tolerar as frustrações das coisas que não aconteciam como ele desejava sem desesperar-se, conseguia reinvestir em outros objetos quando se frustrava, até que começou a namorar outra moça e encontrou um novo campo do direito para exercer a 
sua profissão. Esse outro namoro durou cerca de um ano e estava alicerçado em bases diferentes do tipo de escolha que havia acontecido no namoro com Eduarda.

Falávamos antes de sustentar uma hipótese de que há duas faces do superego, que se alternam conforme o que o ideal do ego incitaria. Talvez possamos ampliar essa hipótese, pensando que uma análise não visa a extinguir o superego, mas, sim, fazer com que a pulsão de morte entrincheirada nessa instância possa religar-se, diminuindo seu caráter mortífero e ampliando sua função protetora - como no humor, em que o superego protege o ego dos males da vida. Um superego cruel que possa ceder espaço para um superego benevolente pode ser uma conquista da análise, já que, para isso, precisaria haver um ideal do ego que instigue o sujeito a produzir de maneira criativa objetos satisfatórios substitutos, transgredindo a ordem tanática das identificações narcísicas. Eugênio cria, na análise, esses novos ideais, a partir da ligação dos excessos por meio de um trabalho de luto psíquico e de uma identificação de confiança, resgatando registros de potencialidade criativa que incitaram o superego a zelar por esse novo ideal. Essa reestruturação do ideal do ego de Eugênio é o que permitiu um reequilíbrio das forças do superego, o que consistiu em dar conta da pulsão de morte presente no superego, e, assim, levar o próprio superego a zelar para que o ideal pudesse concretizar-se por meio de um movimento sublimatório.

Hornstein trabalha a estrutura superegóica, os ideais do eu e a sublimação em publicações que datam desde 1989 até o seu livro mais recente sobre as depressões, publicado em 2006. No capítulo terceiro do livro Las depressiones, defende a proposta de um superego mortífero e também de um superego benevolente, que ele articula com a noção que propõe de humor - esse último como uma formação de compromisso correspondente à série do chiste. Porém, Hornstein adota a postura encontrada no final da obra freudiana de atribuir ao ideal do ego um lugar de subestrutura do superego, diferentemente do que estamos assumindo nessa 
dissertação, de um lugar próprio para o ideal do ego, distinto e independente do superego, ainda que defendamos a proposta de dupla face do superego.

Hornstein (1990), já havia trabalhado a tese de que a sublimação permite ao sujeito autoinvestir-se para reinvestir na realidade, passando por um trabalho de representar o irrepresentável. Ele nos lembra que a sublimação se vincula com a idealização, em muitos aspectos, como, por exemplo, que ambas são modificações das primeiras escolhas de objeto, e são efeito de um trabalho de elaboração psíquica que separa a pulsão de seu apoio primitivo e a conduz até metas não sexuais. Resguarda também as diferenças: enquanto que a sublimação implica uma realização dos ideais, a idealização está a serviço de certa renegação, quer se trate de uma superestimação perversa ou do abandono da atividade crítica em benefício de um líder ou de uma ideologia. Assinamos com Hornstein (1990) que "a sublimação não consiste somente em uma passagem a um nível mais elevado da hierarquia dos valores, mas também uma mudança de um modo de funcionamento psíquico a outro, radicalmente heterogêneo. A sublimação é um processo fecundo de transformação da economia psíquica.” (p.23)

Sem dúvida o caminho a seguir seria adentrar nas relações entre o ideal do ego e a sublimação, o que nos demanda um longo estudo da teoria da sublimação. Se levarmos em conta a relação do superego com a sublimação, o que poderíamos pensar é que o ideal do ego está entre eles e depende dessa instância ideal a possibilidade de constituir, quando isso não é alcançado naturalmente ao longo do desenvolvimento do sujeito, um superego benevolente. Esse, em conformidade com um ideal do ego singular, construído na análise, seria capaz de zelar pela mudança de funcionamento psíquico, permitindo acesso a um modelo sublimatório de potencialidade criativa. O que podemos observar no nosso caso clínico é que, sem dúvida, houve, ao longo dos cinco anos de análise, uma mudança no modo de funcionamento psíquico do paciente, embora saibamos que isso não é garantia de que Eugênio não volte a ter novos padecimentos num outro tempo de vida. 


\section{3 - A transferência é o motor, a sublimação é o produto.}

“Eu não sabia quem eu era, o que eu queria para mim, o que fazer com todo aquele turbilhão de sentimentos de raiva, remorso, culpa que eu sentia em relação ao meu pai. Eu não via futuro para mim. Era como se meu destino estivesse traçado e eu não tivesse saída. Eu morria de medo de começar a vir aqui e me tornar dependente de ti para sempre, e me lembro que tu me perguntaste se depender de ti por um tempo era tão horrível assim. Ali eu entendi que eu precisava me entregar e confiar em ti para ter todas estas respostas que naquela época eram só incógnitas terríveis para mim. (...)” (Eugênio).

A esta altura do trabalho, é necessário encaminharmos algumas questões que esboçamos no início deste capítulo. Sem dúvida, os primeiros contos incluídos na análise podem ser compreendidos como textos neocatárticos, no sentido trabalhado por Ferenczi (1930/1992) de catarse, pois o analisando fez uso da literatura para se apresentar, mas por meio dessa apresentação foi impulsionado a falar dos seus conteúdos traumáticos. Nesse sentido, ler os contos em análise não foi um movimento resistencial do paciente e, sim, uma via de acesso à palavra, necessária para elaborar os lutos, viabilizando uma transformação do estatuto de produção literária de Eugênio.

A severidade do superego, que preconizava um destino familiar, cedeu espaço a um superego cuidador, no sentido de zelar por escolhas que promovessem movimentos de vida, recuperados pelo amor de transferência que viabilizou uma identificação até certo ponto com a analista como representante de um pai amoroso. Os fantasmas que atordoavam Eugênio foram se desfazendo na medida em que acontecia o trabalho de luto necessário à elaboração das questões com essas figuras parentais. O efeito foi a evidente independização egoica 
conquistada. Quando a analista guarda os contos para deixar a cargo do analisando decidir o que fazer com eles, quando ele tivesse recursos para isso, a analista apostava na capacidade de construírem outros modelos de ideais para Eugênio e de reequilibrar o jogo de forças no superego do paciente. A confirmação de que foi possível uma mudança de funcionamento psíquico e de que os textos produzidos durante a análise eram sublimatórios se deu quando ele resolve publicar os contos - e somente aqueles que tinham um estatuto de fantasia.

O caso clínico de Eugênio nos sensibilizou por muitas vias, mas, indiscutivelmente, o atordoamento apresentado pelo paciente nos primeiros tempos de análise, em função dos excessos vividos, era especialmente tocante. Esses excessos mostravam que na história de vida do paciente não havia existido um espaço para fantasiar. A realidade das cenas trágicas se impunha incessantemente na sua infância e adolescência, deixando-o impedido de distanciar-se e de poder fantasiar. Foi justamente o que ele pôde fazer com os contos durante o período de análise. Sem dúvida, estamos falando de contos que, ao longo da análise, transformaram-se em produção sublimatória, pois ele tinha prazer em criar os contos, brincava com suas ideias durante as sessões, e escrevia textos que eram expressões de fantasia e de um lugar para fantasiar. Publicar um livro foi o destino escolhido para os contos criados durante a análise, consistindo numa resposta a ele, à família e à própria analista, dos recursos que agora dispunha para reordenar-se na vida.

A técnica psicanalítica consiste, sem dúvida, num método eficiente para o tratamento de alguns pacientes. Freud desenvolveu, de 1895(/1990), com a hipnose, a 1937(/1990), com a proposta de construções em análise, o desenvolvimento da técnica freudiana foi acompanhando as elaborações metapsicológicas, mantendo constantemente uma coerência entre os dois polos, o teórico e o prático. Analisar nunca foi considerado uma tarefa fácil: existem resistências dos pacientes; exigências de disponibilidade de investimento de tempo, dinheiro e libido, tanto do paciente para tratar-se quanto do analista, que precisa desses 
mesmos ingredientes para manter-se apto à tarefa de analisar; e, por fim, as resistências dos próprios analistas - pois quem já experimentou a tarefa de analisar várias horas por dia sabe o quanto o trabalho transferencial é exaustivo.

Manejar esses três ingredientes é viabilizar e assegurar um lugar de análise para um sujeito. Em 1937(/1990), no último artigo de técnica de Freud, encontramos as últimas formulações acerca da teoria da técnica psicanalítica. O conceito de construção surge para abrir caminho no debate que interessava ao autor na época sobre verdade "histórica" e verdade "material", mas também para resgatar uma ideia de intervenção diferente da interpretação. Se nos primórdios da psicanálise analisar consistia apenas em suspender o recalcamento para que o paciente lembrasse de cenas esquecidas, no fim da vida, Freud amplia essa perspectiva definindo que, além de induzir o sujeito aos recalcamentos próprios de seu desenvolvimento primitivo, era necessário que o paciente substituísse esses comportamentos infantis por reações condizentes com uma condição psiquicamente madura. Ou seja, estava implícita a noção de trabalho psíquico necessário para ocorrerem mudanças, trabalho que iria além de rememorar antigas vivências.

Obviamente que, se o paciente ainda se utiliza de recursos precários, é porque não possui outros recursos egoicos à sua disposição, e nisso é que entendemos que entra a ideia de construção freudiana. No sentido de que não basta interpretar um material trazido pelo paciente, é preciso construir com ele, sob o calor provocado pelo amor transferencial, uma história do sujeito que dê conta de restituir ao ego do paciente a autonomia que lhe foi estirpada pela neurose. Freud (1940[1938](/1990) é bem claro ao dizer que o método que empregamos para o fortalecimento do ego de um paciente é, sem dúvida, um modo de adquirir autoconhecimento. Mas, enfaticamente, afirma que esse não é o objetivo nem todo o trabalho da análise. Suspender o recalcamento é só um primeiro passo, nos lembra o autor: 
"esse primeiro tipo de atividade, como sabemos, destina-se a preparar o caminho para outra tarefa, mais difícil” (1940[1938]/1990 p.205).

A proposta de que uma análise consiste num trabalho de construção restabelece uma dinâmica mais ativa de ambos os sujeitos nela implicados - analisando e analista. Pois, aparentemente, a ideia de interpretação passa uma sensação de que o paciente fica mais passivo ao analista, e de que é o analista quem vai interpretá-lo, como se estivessem um contra o outro numa queda de braço. Uma proposta de que uma análise é uma construção pressupõe um trabalho de dupla, definido por Freud como sendo um trabalho no qual cada um tem um papel bem claro, ambos com funções bem definidas, lugares diferentes e que, juntos, vão promover o tratamento. $\mathrm{O}$ analista, a partir das associações, reações transferenciais, comportamentos do paciente, dentro e fora da análise, constrói trechos da história do paciente a que não teve acesso e, ao comunicar ao paciente, aguarda as novas produções sobre essa construção, produzindo mais material passível de novas construções. Diríamos que é um trabalho artesanal, no qual a dupla investe passo a passo, na busca de um mesmo objetivo que é promover a autonomia do sujeito.

O objetivo de formular as construções não é somente levar o paciente a recordações submersas no inconsciente e, na prática, nem sempre acaba assim. "Em vez disso, se a análise é corretamente efetuada, produzimos nele uma convicção segura da verdade da construção, a qual alcança o mesmo resultado terapêutico que uma lembrança recapturada" (Freud, 1937/1990 p.300). A vivência do paciente, dessa experiência de construção com o analista, produz nele um sentimento capaz de catapultar um tratamento no sentido de restabelecimento das condições de independização do ego, devido à articulação do fragmento de "verdade histórica" (1937/1990 p.302) que a construção possibilita ao sujeito, para preencher o vazio existente devido à rejeição de uma realidade vivenciada. A interpretação é apenas uma ferramenta utilizada em situações bem específicas e delimitadas. 
O trabalho Ferencziano (1931/1992) de propor a técnica do jogo infantil também na análise de adultos parte de uma crítica a Freud quanto a uma frieza e a uma distância afetiva do analista para com o paciente, mais precisamente a frieza que supostamente Freud apresentava. Entrar no jogo da criança ou na fantasia do adulto é descrito como vantajoso da seguinte forma: "É vantagem para a análise quando o analista consegue, graças a uma paciência, uma compreensão, uma benevolência e uma amabilidade quase ilimitadas, ir o quanto possível ao encontro do paciente" (Ferenczi, 1931/1992, p.74). Porém, também encontramos uma preocupação com a questão de não igualar a técnica que ele estava propondo com uma atitude sugestiva do analista. Para tanto, ele cria neologismos, como "intro-sugerir" ou "intro-hipnotizar", para resguardar que não é interessante que o analista passe a fazer coisas que introduzam sugestões ao paciente.

Estamos identificados, de certo modo, com a proposta de Ferenczi (1931/1992) de que em alguns momentos precisamos entrar no jogo do paciente e conversar com ele, como fizemos com Eugênio e os contos que ele trazia para a análise. Como um jogo que nos permitia trabalhar em dupla. Porém, não nos parece pertinente a ideia de que tenha que se optar por um modelo ou outro de técnica. Até porque não concebemos o conceito de neutralidade descrito por Freud como sendo oposto ao que Ferenczi propõe; são manejos clínicos diferentes, mas que pressupõem uma abstinência e uma neutralidade no sentido de não introduzir conteúdos do analista que nada tenham a ver com as questões do paciente. $\mathrm{Na}$ análise de Eugênio, havia momentos em que se fazia absolutamente necessário silenciar para acompanhá-lo em seus relatos e leituras, ao mesmo tempo em que, em outros tantos momentos, eram necessárias intervenções em que a pessoa da analista estivesse diretamente implicada.

Sem dúvida, quando Eugênio podia descolar-se da história vivencial e começar a entrar numa produção mais criativa, num mundo com espaço para fantasias, a conversa 
acontecia em um clima de maior leveza, com momentos de encontro afetivo nos quais surgia alegria e movimentos de independização aconteciam. $\mathrm{O}$ analisando percebia a disponibilidade da analista para entrar em seu jogo e brincar com ele e o convidava a esse movimento sempre falando de um conto seu, de um livro que leu. Ele percebia que isso gerava um clima de encontro afetivo entre os personagens dessa dupla analítica. A proposta de Ferenczi (1931/1992) da análise como ideia de jogo de crianças existiu nesse processo analítico, obviamente que da metade da análise em diante, como um encontro que podia assemelhar-se a uma brincadeira, pois as construções que o trabalho analítico permitia a ambos fazerem transcorriam pela via do compartilhamento de prazer pelo caminho que estavam trilhando.

É possível que essas características não tenham se evidenciado ao longo da dissertação, isso tem a ver com a decisão de não incluir nessa dissertação os contos escritos pelo analisando e, consequentemente, as sessões que mostram o trabalho da análise nesses momentos. Assumimos um compromisso com o comitê de ética da Universidade de São Paulo de que resguardaríamos o máximo possível a identificação do analisando, e, para tanto, não solicitamos um consentimento informado para publicar matérias produzidas por este. Trazer à tona os contos e as conversas sobre estes permitiria claramente identificar de quem se tratava, já que parte dos contos foi publicada. Ao passo que cenas cotidianas de tragédias familiares, de atos de auto e heteroagressões aparecem com frequência na televisão, jornais, na esquina de nossas casas.

Quando Freud escreve em 1937(/1990), sobre o trabalho de análise consistir numa proposta de trabalho conjunto, em que um vai construindo algo a partir do acréscimo produzido pelo outro, e assim sucessivamente, não nos parece que Freud esteja fechando a porta para o que Ferenczi havia pronunciado em 1931(/1992) a respeito de conversar com o paciente. Pois Freud fala de um trabalho que ocorre com a transferência como motor, mas que se concretiza a partir da convicção que for construída pela dupla analítica. Quando 
encontramos as afirmações sobre o trabalho do analista acontecer per via di levare - Freud (1904/1990) toma emprestado de um livro do artista Leonardo da Vinci a diferença entre fazer uma pintura, per via di porre, e uma escultura, que acontece per via di levare - o autor estava apenas no início do desenvolvimento de suas teorias e técnicas. Sempre houve uma consciência de que seu método tinha limites, era um método para neuróticos e tinha objetivos claros. Ele instigava os analistas a seguirem as investigações com pacientes graves como os diagnosticados com psicoses, porque estas ainda nos ensinariam muito.

Pode ser que estejamos adotando uma atitude de positivar a técnica freudiana, mas quando ele fala que o analista constrói trechos de uma história e oferece ao analisando, e que assim abriria espaço para a ideia de também acrescentar algo no tratamento psicanalítico, entendemos que a transferência continua sendo o motor, mas outros esforços podem surgir a partir desse motor. A definição sobre o material que o analista dispunha para fazer suas construções, material este de várias origens possíveis, das lembranças, dos sentimentos e associações dos pacientes, das reações a essas associações, e, ainda, segundo acrescenta Freud, das ações desempenhadas pelo paciente tanto dentro quanto fora da análise, deixa uma abertura para incluirmos aqui ações que não passem por representações-palavra. Os contos traumáticos de Eugênio mostravam que era preciso acrescentar coisas que lhe faltaram para que ele pudesse criar representações-palavras onde não havia.

Sem dúvida, a relação de confiança, inaugurada no processo de análise desse paciente, foi uma maneira de intervir da analista que possibilitou um vínculo que sustentasse a reestruturação do ideal do ego e consequentemente as forças em jogo no superego, abrindo espaço para movimentos de criação. Essa confiança foi construída por meio de atitudes, intervenções, silêncios, posições que a analista tomou de maneira mais ativa, marcando a própria presença, em certos momentos. Nesse sentido, Hausen (2005) propõe: 
Quando representações e passado se afastam da centralidade em nossa clínica, é preciso que o analista se presentifique não como objeto da transferência no sentido da atualização e rememoração, mas como aquele que pode jogar tintas, per via di porre, na tela carente de representações a serem recordadas e ressignificadas (p.46).

A identificação de confiança, de que falamos há pouco, promoveu um espaço de fantasia em Eugênio, que permitiu tornar os contos e as próprias sessões de análise um lugar de alegria, onde ele tinha prazer de estar e criar. Esse acréscimo da analista promoveu uma desidealização das figuras de autoridade e parentalidade, permitindo uma proximidade necessária para transcorrer a análise desse paciente. Nesse sentido, Kupermann (in press) trabalha, por meio de um extenso percurso de investigação teórica, o modelo do humor como paradigma para se pensar o processo de sublimação e a possibilidade de criar:

Ambos implicam processos que se situam na fronteira entre a defesa frente à angústia promovida pelos excessos pulsionais e o movimento criador; encontram suas fontes originárias no brincar infantil; indicam uma afirmação do sujeito e de suas experiências de prazer e de alegria apesar do reconhecimento dos limites impostos a qualquer triunfo onipotente; e, finalmente, produzem uma modalidade de laço social baseado não na repressão pulsional, mas no compartilhamento afetivo (in press).

O humor, para Kupermann (in press), é um instrumento fundamental para o trabalho de desidealização, e, se tomamos a transferência como motor de uma análise, o autor toma a alegria como força motriz da nossa capacidade de criar. Podemos brincar que a análise de Eugênio tinha um motor que nos permitiu construir a confiança e a alegria como força motriz da atividade de criar novos ideais. Um diálogo entre os ideais e as exigências do superego foi uma tarefa promovida durante este processo de análise, permitindo que o superego mortífero cedesse espaço a um superego benevolente que estivesse de acordo com os ideais singulares construídos. 
A confirmação de que esses dois ingredientes promoveram mudanças na vida do analisando, entre tantas aquisições que já marcamos, foi a sua escolha em publicar um livro com os contos que produzira durante o período da análise. A sublimação foi o produto de um longo trabalho empreendido entre lágrimas, conversas, lembranças, risos, contos, silêncios, e, acima de tudo, o desejo de ambos de que o analisando pudesse ter uma vida livre do tão temido destino. Afinal, entendemos que um exercício ético na vida depende de os ideais estarem de acordo com as exigências do superego.

Contamos, no capítulo primeiro, que esse livro só foi dado à analista um ano depois de sua publicação e que isso, para Eugênio, significava o momento de ir embora. Sabíamos dos argumentos utilizados por ele para fazer uma avaliação de seu período de tratamento, mas não tínhamos como saber qual seria o seu futuro, se ele continuaria escrevendo, se encerraria a carreira de escritor junto com a análise, porém, tínhamos a convicção de que ele saberia para onde voltar caso um dia precisasse novamente. Esse momento de finalização dos encontros da análise foi analisado por um tempo, até que a separação dessa dupla também fosse elaborada e que o analisando estivesse convicto de que seria capaz de tornar-se seu próprio cuidador e analista, pois o que haviam construído na análise iria com ele a qualquer lugar.

Entregamos a Eugênio as palavras finais dessa dissertação para elucidar o outro destino, construído no bojo da análise:

"Hoje eи me emociono porque eи vejo que eu sei quem eu sou. Eu sei exatamente quem eu sou, eu sei o que eи quero e o que eu não quero para mim. (...) É muita coisa, muita coisa. Quando eu cheguei aqui eu não via luz no fim do túnel, era tudo escuro, hoje eu vejo que eu ganhei a vida. Eu tenho a vida toda pela frente, eu tenho muito para viver." 


\section{CONSIDERAÇÕES FINAIS}

O nosso projeto inicial consistia em recuperar a instância superegóica como instância organizadora do psiquismo, para inscrevê-la no registro metapsicológico de forma a evidenciá-la como recurso clínico. Tínhamos a proposta de investigar a noção de enclaves psicóticos, trabalhada por Laplanche, a partir da indagação sobre se seriam estes enclaves a origem da severidade do superego. O segundo momento da dissertação consistia em promover um debate metapsicológico sobre a severidade do superego e a sublimação.

Ao longo do percurso de estudos, percebemos que, antes de trabalhar outros autores, era preciso revisar teoricamente as formulações freudianas sobre o superego. Com isso, chegamos à questão que acabou por tornar-se o centro de nossa investigação: a diferença entre superego e ideal de ego. Quem é quem, afinal? Assim, reordenamos o nosso projeto para compreender a constituição, a dinâmica e a economia do superego, a partir dos registros do narcisismo, da pulsão de morte, da temática das identificações e das formulações freudianas e pós-freudianas sobre o superego e o ideal do ego.

Ao finalizar o mestrado, podemos dizer que a grande conquista foi exatamente abrir o questionamento sobre a diferença entre as duas instâncias, pois, na obra freudiana, a todo o momento encontramos impasses e contradições a respeito do que é o ideal do ego e o que é o superego, o que dificulta o entendimento e a condução psicanalítica de certos casos clínicos. Finalizar esse percurso com essa questão bem formulada e algumas respostas encaminhadas é, na nossa percepção, uma conquista, pois o caso clínico que nos conduziu a essa investigação, apresentado no capítulo primeiro, é uma ilustração de um fenômeno cada vez mais comum na contemporaneidade - que são os crimes cometidos no calor dos romances familiares. Esse fato torna o tema mais complexo, na medida em que nos exige pensar em como tratar clinicamente pessoas que cometeram ou estão à beira de cometer certos tipos de 
crime sem ocuparmos posições culturais que inviabilizem o processo. Paradoxalmente, propicia que tenhamos uma visão da dimensão trágica do homem como este vem se apresentando, de uma maneira cada vez mais visível e crescente, no mundo contemporâneo.

Esses fatos violentos dos crimes familiares nos levaram a pensar sobre o cruzamento da pulsão de morte com o superego, na tentativa de compreender como essa instância pode ser responsável por certos tipos de crime, bem como rever a origem e a constituição do superego. Nesse sentido, foi necessária a revisão da teoria das identificações, o que nos permitiu indagar, a partir do caso do Homem dos Ratos, como se constituem os ideais de um sujeito. O capítulo dois, perpassado pelas questões da pulsão de morte, das identificações, dos temas do sentimento de culpa e das heranças que dizem respeito ao superego, demonstra teórica e clinicamente a constituição de uma face violenta dessa instância e suas implicações na vida de um sujeito, restituindo ao superego a importância como conceito metapsicológico, pouco evidenciada nos estudos psicanalíticos atuais.

A partir dessa investigação, estamos assumindo a posição de que o ideal do ego é uma instância psíquica distinta do superego, porém faz-se necessário aprofundar mais o estudo para entender ainda o fator econômico do ideal do ego, para que possamos definitivamente inscrevê-la como conceito metapsicológico. Que o ideal do ego esteve diretamente implicado na transformação das identificações narcísicas em identificações sublimatórias, não há dúvida. Pensamos que, ao longo do terceiro capítulo, foi possível mostrar como o ideal do ego perverso e criminoso que estava instalado no paciente e alimentava o superego mortífero que conduzia o analisando a um destino fechado cedeu espaço a um ideal do ego restituído a partir de uma identificação sublimatória, que propiciava movimentos benevolentes do superego, no caminho da potencialidade criativa do sujeito.

Uma linha de pesquisa a ser continuada é no sentido de como a escuta do analista pode constituir-se sob um ideal que não seja o ideal de uma cultura, pois se escutássemos esse 
analisando com interpretações superegóicas oriundas da cultura psicanalítica, daríamos o paciente como pré-destinado e nada seria alcançado no sentido de transformação das forças conflitantes no superego. Demonstramos, com o exemplo do Homem dos Ratos, que ser um criminoso ou ser um grande homem contém dois ideais enunciados, e consiste numa função analítica resgatar os ideais de potencialidade, erigindo um ideal do ego singular capaz de promover movimentos sublimatórios e levar o sujeito a autoinvestir-se de maneira favorável na vida. A questão é que quando um paciente com essa constelação psíquica chega a uma análise, nem sempre possui recursos para enfrentar uma análise clássica. E um manejo clínico diferente, por vezes, é necessário para criar condições de analisabilidade. O que seria uma técnica analítica per via di porre é uma questão a ser trabalhada.

Se chegamos a uma clara definição do que podemos pensar sobre o superego a partir do material que encontramos em Freud, e de que este tem duas faces, um superego mortífero e um superego benevolente - e também de como cada face se organiza e influencia os destinos de um sujeito -, ainda precisamos confirmar essa nossa formulação com estudos de outros autores pós-freudianos. As funções do superego precisam ser ainda trabalhadas, pois há na obra do Freud o sentimento inconsciente de culpa e o sentimento de culpa que talvez fosse mais bem traduzido como remorso. Essa segunda situação não é abordada com profundidade nesse trabalho, embora o analisando nos traga a todo o momento durante o tratamento, e se liga diretamente com os fenômenos do superego. A resistência do superego, que aparece nas análises como reação terapêutica negativa, é outro ponto que precisa ser aprimorado, pois está diretamente ligada à manifestação da pulsão de morte e, provavelmente, às transferências que acontecem na análise entre analisando e analista. O que indica a necessidade de pensar uma clínica psicanalítica para dar conta dos padecimentos que carecem de representação.

Ao mesmo tempo em que, de um lado, ainda há o que ser investigado sobre o superego e sobre o ideal do ego, sem dúvida a sublimação entra como um ponto que está do outro lado 
da cadeia desses processos, como uma saída para os destinos mortíferos. O problema clínico fundamental é transformar um superego mortífero em superego benevolente, que permita ao ideal do ego incitar ao movimento sublimatório. Para darmos conta dessa cadeia que inicia no superego mortífero e resulta nos movimentos sublimatórios, é necessário um longo investimento de estudos no tema da sublimação, no que consiste esse destino pulsional, os temas que estão ligados às duas teorias freudianas da sublimação e, sem dúvida, na função do analista para promover essa transformação.

Uma nova pesquisa enfocando o ideal do ego e a sublimação pode ser o caminho mais fecundo para dar continuidade ao que estamos investigando aqui, pois o curto espaço de tempo de um mestrado não permite que abordemos numa só pesquisa dois assuntos tão amplos, como o superego e a sublimação, como pretendíamos no projeto inicial. O tema da sublimação, das produções literárias como movimentos sublimatórios e da sublimação como recurso clínico pôde muito brevemente ser abordado nesse estudo, porque foi um movimento fundamental nesse processo de análise. Esse é um caminho que apontamos como uma forte tendência a ser desenvolvida na pesquisa de doutorado. O tema da dessexualização pulsional, uma incógnita na obra freudiana, nos leva a questionar as forças implicadas no movimento sublimatório e no movimento de constituição do superego. Reunindo novamente essas duas instâncias, mas fazendo um percurso teórico sobre sublimação, será possível fazer um debate metapsicológico mais aprofundado sobre elas, apenas esboçado nessa dissertação.

Quando entramos no capítulo terceiro, nas questões referentes ao manejo clínico desse caso, que nos fez pensar nos contos traumáticos, na neocatarse, na análise a partir do modelo da teoria dos sonhos, no tema das construções, percebemos com clareza que a técnica de Freud dá conta de tratamentos das pessoas com padecimentos referentes às questões do desamparo. Em certos casos, nos quais há uma predominância da pulsão de morte e o superego é mortífero, exigem-se do analista recursos diferentes dos utilizados para conduzir 
um tratamento pela interpretação. Fez-nos sentido pensar que há necessidade de trabalhar a metapsicologia da orfandade psíquica, que se abre como uma possibilidade diferente de seguimento para essa pesquisa.

Por fim, gostaríamos de fazer um registro sobre a diferença entre conduzir um caso clínico a partir do lugar de analista e de teorizar um caso clínico dentro da academia. Alguns impasses foram encontrados nesse percurso, principalmente no que diz respeito à dinâmica da escuta. Numa análise, a escuta analítica está alicerçada na inquestionável atenção flutuante, fator que não está implicado numa produção acadêmica. Uma produção acadêmica exige um desenvolvimento e uma organização teórica a partir de um raciocínio construído numa interlocução teórica com autores diversos que o sustentam com seus argumentos. Isso é outra coisa, diferente de uma análise, e pensamos ser necessário discriminar o valor de cada um dos espaços, sem fazer juízo de valor ou esquecer o que os diferencia, de forma a levá-los a se enriquecerem mutuamente. 
ANEXOS 


\begin{abstract}
ANEXO 1
Pedido de Aprovação de pesquisa enviado ao Comitê de Ética em Pesquisa com Seres Humanos do Instituto de Psicologia da Universidade de São Paulo (CEPH-IP)
\end{abstract}




\section{UNIVERSIDADE DE SÃO PAULO INSTITUTO DE PSICOLOGIA COMITE DE ÉTICA EM PESQUISA HUMANA-CEPH}

FORMULÁRIO DE ENCAMINHAMENTO

PROTOCOLO CEPH No. RECEBIDO EM:

\section{DADOS DA PESQUISA}

Título do PROJeto de PESQUISA: SUPEREGO E SUBLIMACÃO: UM DESTINO AO ROMANCE FAMILIAR.

OBJETIVOS, SUJEITOS E MÉTODO dO PROJETO DE PESQUISA:

OS OBJETIVOS SÃO: INVESTIGAR A DINÂMICA DA INSTÂNCIA SUPEREGÓICA NA SUA EXTENSÃO TANTO CIVILIZATÓRIA COMO POTENCIALIDADE NO CAMPO DA CLÍNICA PSICANALÍTICA: REVISAR NA OBRA FREUDIANA O DESENVOLVIMENTO DO CONCEITO DE SUBLIMAČ̃̃O PARA INSCREVÊ-LO NA DIMENSÃO DE CONCEITO METAPSICOLOGICO; ARTICULAR OS CONCEITOS PSICANALITICOS DE SUPEREGO E DE SUBLIMACÃO PARA INVESTIGAR A CONDICÃO SUBLIMATÓRIA NA CONSTITUICÃO DO SUPEREGO.

O SUIEITO SERÁ UM RAPAZ OUE FEZ PSICOTERAPIA PSICANALÍTICO DURANTE UM PERIODO DE 5 ANOS TENDO ALTA DO SEU PROCESSO DE TRATAMENTO HÁ CERCA DE QUATRO ANOS.

O MÉTODO UTLIZADO SERÁ O DE TRABALHAR COM UMA REFEXÃO PÓS FATOS, JÁ OUE O TRATAMENTO DO RAPAZ JÁ FOI ENCERRADO, SENDO QUE PARA ISSO SERÁ UTILIZADO DOCUMENTOS PRODUZIDOS NA ÉPOCA DO TRATAMENTO PELA ANALISTA QUE CONDUZIU O CASO. ESSES DOCUMENTOS ERAM RELATADOS AO TÉRMINO DE CADA SESSÃO, E DESTES SERÃO RETIRADOS ALGUNS FATOS CLÍNICOS, APENAS AQUELES OUE TENHAM RELACÃO COM O TEMA DO SUPEREGO E QUE SIRVAM PARA ILUSTRAR A RELACÃO DO SUEPREGO E DA SUBLIMACÃO, NÃO EXPONDO TODA A EXTENSÃO E A PROFUNDIDADE DO CASO CLÍNICO EM QUESTÃO.

QUESTÕES ÉTICAS ENVOLVIDAS E PROCEDIMENTOS ADOTADOS RELATIVOS A ESSAS QUESTÕES:

AS QUESTŐES ÉTICAS ENVOLVIDAS NESSE PROJETO SÄO AS DE PRESERVAR A IDENTIDADE E A PRIVACIDADE DO SUJEITO QUE ESTARÁ IMPLICADO NO TRABALHO, BEM COMO SUA INTEGRIDADE E SAÚDE FISICA E EMOCIONAL. OS PROCEDIMENTOS QUE SERÃO ADOTADOS PARA RESPEITAR ESSAS QUESTÕES SÃO QUATRO: NENHUM DADO QUE POSSA IDENTIFICAR O SUJEITO SERA REVELADO E UTILIZADO DURANTE O TRABALHO; FOI ESCOLHIDO UM CASO CLÍNICO EM QUE O TRATAMENTO JÁ FOI ENCERRADO ALGUM TEMPO DE MANEIRA QUE A PESQUISA CONSISTIRÁ NUMA REFLEXÃO DOCUMENTAL PÓS-FATO E NÃO OCORRERÁ DURANTE O ANDAMENTO DO TRATAMENTO O QUE PODERIA ACARRETAR INTERFERÊNCIAS NO TRATAMENTO; O TRABALHO SERÁ REALIZADO COM FATOS CLINICOS E NÃO COM ANÁLISE DO CASO CLÍNICO EM PROFUNDIDADE E EXTENSÄO POUPANDO, ASSIM, O SUJEITO DE EXPOSICĀO DEMASIADA; E POR FIM, FOI ESCOLHIDO UM PACIENTE QUE TENHA SIDO TRATADO COM UM PROCESSO TERAPÉUTICO QUE TENHA UMA TÉCNICA JA CONSAGRADA QUE É A PSICANÁLISE, SENDO QUE FICA GARANTIDA A INTEGRIDADE FISICA E EMOCIONAL DO SUJEITO DE QUALQUER EXPERIMENTACÄO COM TÉCNICAS DESCONHECIDAS.

IDENTIFICAÇĀO DE INTERESSES DE ORDEM FINANCEIRA REAIS E/OU POTENCIAIS DO PROJETO:

O PROJETO TEM GRANDE RELEVANCIA PARA O TRABALHO NA CLINICACA PSICANALÍTICA NO QUE DIZ RESPEITO A VIOLENCIA FAMILIAR E A CERTOS TIPOS DE CRIMES COMETIDOS PELA INFLUENCIA DO SUPEREGO. PORTANTO, FINANCIAR ESTE PROJETO PODE SER UMA FORMA DE INCENTIVAR UM TRABALHO QUE TRAGA COMPREENSÃO NOS FENÔMENOS AVASSALADORES DE VIOLÊNCIA QUE ASSISTIMOS CADA VEZ MAIS CRESCENTE NA SOCIEDADE E DENTRO DAS PRÓPRIAS FAMILIAS, COMO PAIS MATANDO FILHOS, FILHOS MATANDO PAIS, CRIMES PASSIONAIS, E OUTROS TIPOS DE CRIMES FAMILIARES INFLUENCIADOS PELA SEVERIDADE DO SUPEREGO.PENSAR A ARTICULACÄO TEÓRICA DA SUBLIMACĀO E DO SUPEREGO É PENSAR A POSSIBILIDADE DE TRATAMENTO PARA ESSE TIPO DE CONFIGURACĀO PSIQUICA.

FINANCIADORIES: $\underline{\text { CAPES }}$

ESCLARECIMENTOS SOBRE OS DADOS DA PESQUISA:

NESTA PESQUISA NÃO SERÁ TRABALHADO UM CASO CLINICO, SERA UTILIZADO APENAS ALGUNS FATOS CLINICOS, RETIRADOS DE DOCUMENTOS PRODUZIDOS PELA ANALISTA QUE CONDUZIU O TRATAMENTO NA ÉPOCA EM QUE ELE OCORREU PARA REALIZAR UMA REFLEXÃO TEÓRICA QUE PROMOVA A POSSIBILIDADE DE 
ENTENDIMENTO TEÓRICO DOS CONCEITOS ESTUDADOS. SERÁ UMA REFLEXÃO PÓS-FATOS JÁ QUE ESTARA SENDO USADO MATERIAL DE UM CASO QUE JÁ FOI CONCLUIDO A MAIS DE QUATRO ANOS E NÃO MATERIAL DF SENDO USADO MATERIALDE UM CASOQUE JAFOI CONCLDOA UM TRATAMENTO REALIZADO EM TEMPO REAL AO DA PESQUSA. POR ESSE MOTIVO CONSIERA-SE ESTA UMA PESQUISA CLINIICA DOCUMENTAL E PORTANTO SEM NECESSIDADE DE CONSENTIMENTO ESCLARECIDO.

(ANEXAR FORMÚLARIO DE CONSENTIMENTO ESCLARECIDO DE ACORDO COM A CONEP-QUANDO FOR O CASO)

FINALIDADE DA PESQUISA:

INICIAÇÃo CIENTIFical ; Mestrado (X) DOUTORAdo ( ) PÓS-DOUTORAdo ( )

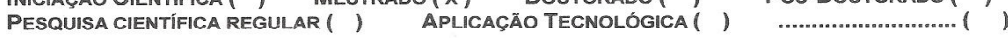




\begin{abstract}
ANEXO 2
Parecer do Comitê de Ética em Pesquisa com Seres Humanos do Instituto de Psicologia da Universidade de São Paulo (CEPH-IP)
\end{abstract}




\section{UNIVRSIDADE DE SAOPAULO \\ INSTITUTO DE PSICOLOGIA \\ CEPH - COMHÊ DE ÉTICA EM PESQUTSA HUMA NA COM SERES HUMANOS}

Registro CEPII No 2008.039

Titulo do Projeto: Superego e sublinaçầ : Um destino ao romance familiar

Pesquisador: Lizana Dallazen

Orientador: Prot. Daniel Kupermann

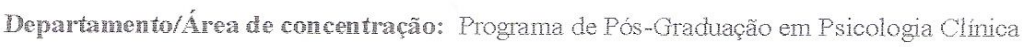

\section{PARECER}

Este projeto apresenta como objetivo: Investigar a instância superegóica na sua extensão tanto civilizatónia como potencialidade no campo da clinica psicanalitica.

Esta pesquisa conforme coloca o pesquisador, abrange uma revisão e una discussão metapsicologica de conceitos fundamentais da psicanahise: superego a sublinaça, com a justificativa de destaca-los como recursos importantes a prática clinica

Apresenta como objetivos:

1) Geral: Explorar inquietaçóes metapsicológicas e téenicas suscitadas no exercício da clinica psicanalitica a respeito da relaçâo entre o superego e a sublimaçâo.

2) Especificos: a) Investigax a dinâmica da instância superegóica na sua extensăo tanto civilizatória como potencialidade no campo da clínica psicanalitica; b) Revisar na obra freudiana o desenvolvinento do conceito de sublimaça para insorevelo na dimensäo de conceito metapsicologico; o) Articular os conceitos psicanaliticos de superego e de sublimaçáo para investigar a condiçăo sublimatóra na conistituiçầ do superego.

No percurso deste trabalho de revisão dos conceitos de superego e sublimaçáo em Freud e en outros autores posteriores a este, fragmentos de una situaça clínica vivida há cinoo anos atrás serâo utilizados para o desenvolvimento do raciocinio dinico e consequente articulação entre os conceitos, além de ilustrar no conjunto de prohucoes mentais que surgiram no transcurso do tratamento psicanaltico o de bate sobre o tema da pesquisa.

Trata-se de um estudo teórico-clinico com as caracteristicas de una pesquisa documental que lanęa mäo, inclisive, de una situaça clinica, vivida pelo pesquisador há cinco anos, cujos registros das sessöes no periodo de tratamento serão utilizados para as reflexoes a que se propóe, sendo que este paciente recebeu alta há 04 (quatro) anos, conforme nos informa o pesquisador.

0 fato de pesquisador lançar ma de uma historia clinica para sustentar suas reflexbes teónco-clinicas mereceu atençẫo deste parecerista. O pesquisador assegura que dados de identificaça serăo modificados e aqueles que porventura forem utilizados năo permitira a identificaça do paciente em questăo, portanto, nåo existe quebra às nomas de confidenctalidade, sigilo e anonimato, além disto, o material utilizado no estudo trata-se de uma elaboraçầ a posterion de aspectos psicológicos concernentes aos objetivos da pesquisa e, por fin nâo exposiça do "sujeito" a experimento. Note-se que coloco entre aspas o temo, sujeito, pois esta pescuisa nâ se constitui em estudo de caso stricto senso, mas sim a utilizaço de fatos clinicos ocorridos e evidencudos no transourso de un traballhe analitico, registrados pelo profissional que conduziu o caso e ane permitirá, no contexto desta pesquisa, uma reflexáo documental.

Este projeto é considerado.

( $)$ anrovado

( ) aprovado con mecessidade de apresentaz toformulações

( ) pendente com necessidade de apresentar wofmulaçes para ser aprovado

( ) reprovado 


\section{Referências}

Benjamin, W. Obras escolhidas III: Charles Baudelaire, um lírico no auge do capitalismo (J. C. Martins Barbosa e H. A. Baptista, Trads.). São Paulo: Brasiliense, 1989.

Birman, Joel (1999). A servidão na psicanálise. In: A. P. Furtado (Org.), Fascínio \& Servidão (pp. 7-20). Belo Horizonte: Autentica.

Bleichmar, H. (1985). O narcisismo: Estudo sobre a enunciação e a gramática inconsciente. Porto Alegre: Artes Médicas.

Botelho, J. F. (2006, Junho). Opus Dei. Revista Superinteressante, 227, 56-65.

Carvalho, A. C. (1997). Escrita: remédio ou veneno. Percurso 18(1), 79-86.

Castiel, S. (2007). Sublimaçao: Clinica e metapsicologia. São Paulo: Escuta.

Chasseguet-Smirgel, J. (1992). O Ideal do Ego. Porto Alegre: Artes Médicas.

Fédida, P. (1988). A clínica psicanalítica: Estudos. São Paulo: Editora Escuta.

Fédida, P. (1991). Nome, figura e memória: A linguagem na situação psicanalítica. São Paulo: Editora Escuta.

Ferenczi, S. (1930/1992). Princípio de relaxamento e neocatarse. In A. Cabral (Trad.), Obras Completas de Sándor Ferenczi: Vol. 4. Psicanálise IV (1ª ed., pp. 53-68). São Paulo: Martins fontes.

Ferenczi, S. (1931/1992). Análise de crianças com adultos. In A. Cabral (Trad.), Obras Completas de Sándor Ferenczi: Vol. 4. Psicanálise IV (1 ${ }^{a}$ ed., pp. 69-83). São Paulo: Martins fontes.

Ferenczi, S. (1932/1997a). Retorno del trauma en síntomas, en sueños y en la catarsis, represión y división de la personalidad, desconstrucción de la represión el la catarsis y tras esta. In J. Dupont (Trad.), Diario Clínico (pp. 114-116). Buenos Aires: Amorrortu Editores S.A. 
Ferenczi, S. (1932/1997b). El empantanamiento en la catarsis y su remédio. In J. Dupont, Diario Clínico (pp.66-70). Buenos Aires: Amorrortu Editores S.A.

Freud, S. (1895/1990). Projeto para uma Psicologia Científica. In J. Strachey (Ed. e Trad.), Edição Standard Brasileira das Obras Psicológicas Completas de Sigmund Freud: Vol. 1. Publicações Pre-psicanalíticas e esboços inéditos (3ª ed., pp. 387-547). Rio de Janeiro: Imago.

Freud, S. (1896/1990). Carta 52. In J. Strachey (Ed. e Trad.), Edição Standard Brasileira das Obras Psicológicas Completas de Sigmund Freud: Vol. 1. Publicações Prepsicanalíticas e esboços inéditos ( $3^{\text {a }}$ ed., pp. 324-331). Rio de Janeiro: Imago.

Freud, S. (1897/1990). Carta 69. In J. Strachey (Ed. e Trad.), Edição Standard Brasileira das Obras Psicológicas Completas de Sigmund Freud: Vol. 1. Publicações Prepsicanalíticas e esboços inéditos ( $3^{\text {a }}$ ed., pp. 357-359). Rio de Janeiro: Imago.

Freud, S. (1897/1990). Rascunho M. In J. Strachey (Ed. e Trad.), Edição Standard Brasileira das Obras Psicológicas Completas de Sigmund Freud: Vol. 1. Publicações Prepsicanalíticas e esboços inéditos ( $3^{\text {a }}$ ed., pp. 346-351). Rio de Janeiro: Imago.

Freud, S. (1900/1990a). A interpretação dos sonhos. In J. Strachey (Ed. e Trad.), Edição Standard Brasileira das Obras Psicológicas Completas de Sigmund Freud: Vol.4. A interpretação dos sonhos (Parte I) (3 $3^{\text {a }}$ ed., pp.119-140). Rio de Janeiro: Imago.

Freud, S. (1900/1990b). A interpretação dos sonhos. In J. Strachey (Ed. e Trad.), Edição Standard Brasileira das Obras Psicológicas Completas de Sigmund Freud: Vol. 5. A interpretação dos sonhos (Parte II) Sobre os sonhos ( $3^{\mathrm{a}}$ ed., pp. 468-533). Rio de Janeiro: Imago.

Freud, S. (1905/1990a). Fragmento da análise de um caso de histeria. In J. Strachey (Ed. e Trad.), Edição Standard Brasileira das Obras Completas de Sigmund Freud: Vol. 7. 
Um caso de histeria, Três ensaios sobre sexualidade e outros trabalhos ( $3^{\mathrm{a}} \mathrm{ed} . \mathrm{pp}$. 12-115). Rio de Janeiro: Imago.

Freud, S. (1905/1990b). Os chistes e sua relação com o inconsciente. In J. Strachey (Ed. e Trad.), Edição Standard Brasileira das Obras Psicológicas Completas de Sigmund Freud: Vol. 8 Os chistes e sua relação com o inconsciente ( $3^{\mathrm{a}}$ Ed.). Rio de Janeiro: Imago.

Freud, S. (1908/1990a). Moral sexual "civilizada" e doença nervosa moderna. In J. Strachey (Ed. e Trad.), Edição Standard Brasileira das Obras Psicológicas Completas de Sigmund Freud: Vol. 9. "Gradiva” de Jensen e outros trabalhos ( $3^{\mathrm{a}}$ ed., pp. 187-212). Rio de Janeiro: Imago.

Freud, S. (1908/1990b). Escritores criativos e devaneios. In J. Strachey (Ed. e Trad.), Edição Standard Brasileira das Obras Psicológicas Completas de Sigmund Freud: Vol. 9. "Gradiva” de Jensen e outros trabalhos ( $3^{\mathrm{a}}$ ed., pp. 147-160). Rio de Janeiro: Imago.

Freud, S. (1909/1990). Notas sobre um caso de neurose obsessiva. In J. Strachey (Ed. e Trad.), Edição Standard Brasileira das Obras Completas de Sigmund Freud: Vol. 10. Duas histórias clínicas (O “pequeno Hans” e o "Homem dos ratos”) (3ª ed., pp. 157250). Rio de Janeiro: Imago.

Freud, S. (1910/1990). Leonardo da Vinci e uma lembrança da sua infância. In J. Strachey (Ed. e Trad.), Edição Standard Brasileira das Obras Completas de Sigmund Freud: Vol. 11. Cinco Lições de Psicanálise, Leonardo Da Vinci e outros trabalhos ( $3^{\mathrm{a}}$ ed., pp. 53-124). Rio de Janeiro: Imago.

Freud, S. (1912/1990a). A Dinâmica da Transferência. In J. Strachey (Ed. e Trad.), Edição Standard Brasileira das Obras Completas de Sigmund Freud: Vol. 12. O caso de Schereber, Artigos sobre técnica e outros trabalhos (3 ${ }^{\mathrm{a}}$ ed., pp. 131-143). Rio de Janeiro: Imago. 
Freud, S. (1912/1990b). Recomendações aos médicos que exercem a psicanálise. In J. Strachey (Ed. e Trad.), Edição Standard Brasileira das Obras Psicológicas Completas de Sigmund Freud: Vol. 12. O caso Schereber, Artigos sobre técnica e outros trabalhos ( $3^{\text {a }}$ ed., pp. 147-160). Rio de Janeiro: Imago.

Freud, S. (1913/1990). Totem e tabu. In J. Strachey (Ed. e Trad.), Edição Standard Brasileira das Obras Completas de Sigmund Freud: Vol. 13. Totem e Tabu e outros trabalhos (3 ${ }^{\mathrm{a}}$ ed., pp. 13-162). Rio de Janeiro: Imago.

Freud, S. (1914/1990a). Sobre o Narcisismo: Uma introdução. In J. Strachey (Ed. e Trad.), Edição Standard Brasileira das Obras Completas de Sigmund Freud: Vol. 14. A História do Movimento Psicanalítico, Artigos sobre metapsicologia e outros trabalhos ( $3^{\text {a }}$ ed., pp. 85-119). Rio de Janeiro: Imago.

Freud. S. (1914/1990b). Recordar, repetir e elaborar. In J. Strachey (Ed. e Trad.), Edição Standard Brasileira das Obras Psicológicas Completas de Sigmund Freud: Vol. 12. O Caso Schereber, Artigos sobre técnica e outros trabalhos ( $3^{\text {a }}$ ed., pp. 191-203). Rio de Janeiro: Imago.

Freud, S. (1915/1990a). Pulsões e destinos da pulsão. In J. Strachey (Ed. e Trad.), Edição Standard Brasileira das Obras Completas de Sigmund Freud: Vol. 14. A História do Movimento Psicanalítico, Artigos sobre metapsicologia e outros trabalhos ( $3^{\mathrm{a}}$ ed., pp. 129-162). Rio de Janeiro: Imago.

Freud, S. (1915/1990b). Observações sobre o amor transferência. In J. Strachey (Ed. e Trad.), Edição Standard Brasileira das Obras Completas de Sigmund Freud: Vol. 12. O caso Schereber, Artigos sobre técnica e outros trabalhos ( $3^{\text {a }}$ ed., pp. 207-221). Rio de Janeiro: Imago.

Freud, S. (1916/1990). Alguns tipos de caráter encontrados no trabalho psicanalítico (Parte 3: Criminosos em Consequência de um Sentimento de Culpa). In J. Strachey (Ed. e Trad.), 
Edição Standard Brasileira das Obras Completas de Sigmund Freud: Vol. 14. A História do Movimento Psicanalítico, Artigos sobre metapsicologia e outros trabalhos ( $3^{\text {a }}$ ed., pp. 375-377). Rio de Janeiro: Imago.

Freud, S. (1917 [1916-1917]/1990a). Os caminhos da formação dos sintomas. In J. Strachey (Ed. e Trad.), Edição Standard Brasileira das Obras Completas de Sigmund Freud: Vol.16. Conferências Introdutórias sobre Psicanálise (Parte III). (3 ${ }^{\mathrm{a}}$ ed., pp. 419-440). Rio de Janeiro: Imago.

Freud, S. (1917/1990b). Luto e Melancolia. In J. Strachey (Ed. e Trad.), Edição Standard Brasileira das Obras Completas de Sigmund Freud: Vol. 14. A História do Movimento Psicanalítico, Artigos sobre metapsicologia e outros trabalhos ( $3^{\mathrm{a}}$ ed., pp. 271-292). Rio de Janeiro: Imago.

Freud, S. (1919/1990a). O estranho. In J. Strachey (Ed. e Trad.), Edição Standard Brasileira das Obras Completas de Sigmund Freud: Vol. 17. Uma neurose infantil e outros trabalhos (3 ${ }^{\mathrm{a}}$ ed., pp. 273-314). Rio de Janeiro: Imago.

Freud, S. (1919/1990b). Uma criança é espancada: Uma contribuição ao estudo da origem das pervesões sexuais. In J. Strachey (Ed. e Trad.), Edição Standard Brasileira das Obras Psicológicas Completas de Sigmund Freud: Vol. 17. Uma neurose infantil e outros trabalhos ( $3^{\mathrm{a}}$ ed., pp. 223-253). Rio de Janeiro: Imago.

Freud, S. (1920/1990). Além do princípio do prazer. In J. Strachey (Ed. e Trad.), Edição Standard Brasileira das Obras Completas de Sigmund Freud: Vol. 18. Além do Princípio do Prazer, Psicologia de grupo e outros trabalhos (3 ${ }^{\mathrm{a}}$ ed., pp. 13-85). Rio de Janeiro: Imago.

Freud, S. (1921/1990). Psicologia de grupo e a análise do ego. In J. Strachey (Ed. e Trad.), Edição Standard Brasileira das Obras Completas de Sigmund Freud: Vol. 18. Além do 
Princípio do Prazer, Psicologia de Grupo e outros trabalhos ( $3^{\text {a }}$ ed., pp. 119-148). Rio de Janeiro: Imago.

Freud, S. (1923/1990). O Eu e o Id. In J. Strachey (Ed. e Trad.), Edição Standard Brasileira das Obras Completas de Sigmund Freud: Vol. 19. O Ego e o Id, Uma neurose demoníaca do século XVII e outros trabalho ( $3^{\mathrm{a}}$ ed., pp. 13-83). Rio de Janeiro: Imago.

Freud, S. (1924/1990a). A dissolução do complexo de Édipo. In J. Strachey (Ed. e Trad.), Edição Standard Brasileira das Obras Completas de Sigmund Freud: Vol. 19. O Ego e o Id, Uma neurose demoníaca do século XVII e outros trabalhos ( $3^{\mathrm{a}}$ ed., pp. 215-226). Rio de Janeiro: Imago.

Freud, S. (1924/1990b). A perda da realidade na neurose e na psicose. In J. Strachey (Ed. e Trad.), Edição Standard Brasileira das Obras Completas de Sigmund Freud: Vol. 19. O Ego e o Id, Uma neurose demoníaca do século XVII e outros trabalhos ( $3^{\mathrm{a}}$ ed., pp. 227236). Rio de Janeiro: Imago.

Freud, S. (1924/1990c). O problema econômico do masoquismo. In J. Strachey (Ed. e Trad.), Edição Standard Brasileira das Obras Completas de Sigmund Freud: Vol. 19. O Ego e o Id, Uma neurose demoníaca do século XVII e outros trabalhos ( $3^{\mathrm{a}}$ ed., pp. 197-212). Rio de Janeiro: Imago.

Freud, S. (1926/1990). Inibição, sintoma e angústia. In J. Strachey (Ed. e Trad.), Edição Standard Brasileira das Obras Completas de Sigmund Freud: Vol. 20. Um estudo autobiográfico, Inibições, sintomas e ansiedade, A questão da análise leiga e outros trabalhos ( $3^{\mathrm{a}}$ ed., pp. 95-201). Rio de Janeiro: Imago.

Freud, S. (1927/1990a). O futuro de uma ilusão. In J. Strachey (Ed. e Trad.), Edição Standard Brasileira das Obras Completas de Sigmund Freud: Vol. 21. O futuro de uma ilusão, O mal estar na civilização e outros trabalhos ( $3^{\mathrm{a}}$ ed., pp. 13-71). Rio de Janeiro: Imago. 
Freud, S. (1927/1990b). O humor. In J. Strachey (Ed. e Trad.), Edição Standard Brasileira das Obras Completas de Sigmund Freud: Vol. 21. O futuro de uma ilusa, O mal estar na civilização e outros trabalhos ( $3^{\text {a }}$ ed., pp. 188-194). Rio de Janeiro: Imago.

Freud, S. (1930/1990). O mal estar na civilização. In J. Strachey (Ed. e Trad.), Edição Standard Brasileira das Obras Completas de Sigmund Freud: Vol. 21. O futuro de uma ilusão, O mal estar na civilização e outros trabalhos (3a ed., pp. 75-171). Rio de Janeiro: Imago.

Freud, S. (1933/1990). A dissecação da personalidade psíquica. In J. Strachey (Ed. e Trad.), Edição Standard Brasileira das Obras Completas de Sigmund Freud: Vol. 22. Novas Conferências Introdutórias e outros trabalhos (3 ${ }^{\mathrm{a}}$ ed., pp. 63-84). Rio de Janeiro: Imago.

Freud, S. (1937/1990). Construções em análise. In J. Strachey (Ed. e Trad.), Edição Standard Brasileira das Obras Completas de Sigmund Freud: Vol. 23. Moisés e o Monoteísmo, Esboço de Psicanálise e outros trabalhos (3 ${ }^{\text {a }}$ ed., pp. 289-304). Rio de Janeiro: Imago.

Freud, S. (1940[1938]/1990). Esboço de psicanálise. In J. Strachey (Ed. e Trad.), Edição Standard Brasileira das Obras Completas de Sigmund Freud: Vol. 23. Moisés e o Monoteísmo, Esboço de Psicanálise e outros trabalhos ( $3^{\mathrm{a}}$ ed., pp. 165-237). Rio de Janeiro: Imago.

Green, A. (2005). Narcisismo de vida, narcisismo de muerte. Buenos Aires: Amorrortu Editores.

Hausen, D. (2005). Per via de porre, uma intervenção psicanalítica? In: M. M. K. Macedo \& L. K. Carrasco (Con)textos de entrevista: olhares diversos sobre a interpretação humana (pp. 34-48). São Paulo: Casa do Psicólogo.

Hornstein, L. (1989). Introdução a psicanálise. (M. A. Santa Cruz, Trad.). São Paulo: Editora Escuta. 
Hornstein, L. (1990). Cura psicanalítica e sublimação? (F.F.Settineri, Trad.). Porto Alegre: Artes Médicas.

Hornstein, L. (2006). Las depresiones. Buenos Aires: Paidós.

Kahtuni, H. C. \& Sanches, G. P. (2009). Dicionário do pensamento de Sándor Ferenczi. São Paulo: FAPESP.

Kehl, M. R. (2002). Sobre ética e psicanálise. São Paulo: Companhia das Letras.

Kristeva, J. (2002). As novas doenças da alma. Rio de Janeiro: Rocco.

Kupermann, D. (1996). Transferências Cruzadas: Uma história da Psicanálise e suas instituições. Rio de Janeiro: Revan.

Kupermann, D. (2003). Ousar rir: Humor, criação e psicanálise. Rio de Janeiro: Civilização Brasileira.

Kupermann, D. (2008). Presença sensível: Cuidado e criação na clínica psicanalítica. Rio de Janeiro: Civilização Brasileria.

Kupermann, D. (in press). Humor, desidealização e sublimação na psicanálise. Psicologia Clinica 22(1).

Laplanche, J., \& Pontalis, J. B. (1992). Vocabulário de Psicanálise (2a ed.). São Paulo: Martins Fontes.

Larousse, K. (1980). Pequeno Dicionário Enciclopédico. Rio de Janeiro: Larousse.

Mahony, P. J. (1991). Freud e o Homem dos Ratos. São Paulo: Escuta.

Mayer, H. (1989). Votar a Freud. Porto Alegre: Artes Médicas.

Mezan, R. (1998). Escrever a clínica. São Paulo: Casa do Psicólogo.

Mijolla-Mellor, S. (2005). La sublimation. Paris: Presses Universitaires de France.

Mijolla-Mellor, S.(2008). A escrita é um escudo contra a loucura? Trabalho apresentado no colóquio Razão, Loucura e Criação realizado na Universidade de São Paulo, São Paulo, SP. 
Oliveira, M. D., \& Rosa, J. T. (2001). Fatos clínicos psicanalíticos na psicoterapia de uma paciente com depressão narcísica. In J. T. Rosa (Org.), Mudanças: Psicoterapia e Estudos Psicossociais. Curso de Pós Graduação em Psicologia da Saúde, 1 (1), (1140). São Bernardo do Campo: UMESP.

Seligmann-Silva, M. (2000). A história como trauma. In M. Seligmann-Silva \& A. Nestrovski (Orgs.), Catástrofe e Representação (pp. 73-98). São Paulo: Escuta. 